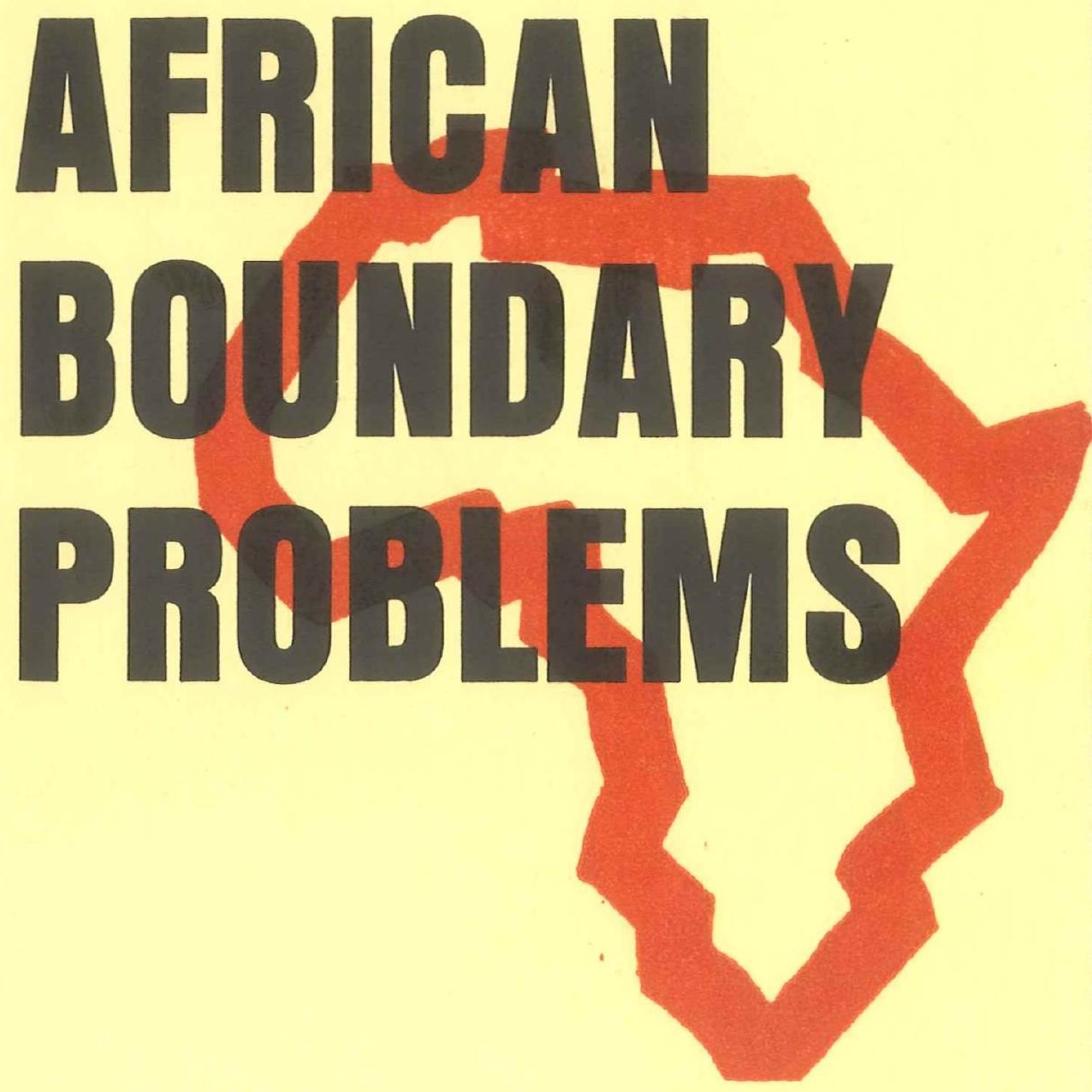

Edited by

GARL GÖSTA WIDSTRAND 

African Boundary Problems 


\section{AFRICAN \\ BOUNDARY \\ PROBLEMS}

E DITED BY

Carl Gösta Widstrand

GONTRIBUTORS:

Anthony Allott, Samuel Chime, Anat. A. Gromyko, Kenneth W. Grundy, Benedict V. Mtshali, Knud Erik Svendsen, Saadia Touval, Sven Tägil, Jokica Hadži-Vasileva, I. William Zartman

The Scandinavian Institute of African Studies U P P S ALA I 969 
The Scandinavian Institute of African Studies has served at Uppsala since 1962 as a Scandinavian documentation and research centre on African affairs. The views expressed in its publications are entirely those of the authors and do not necessarily reflect the views of the Institute.

\section{Q 1969 Nordiska Afrikainstitutet \\ All rights reserved}

Printed in Sweden by

Almqvist \& Wiksells Boktryckeri Aktiebolag

Uppsala 1969 


\section{Contents}

I. PREFAGE 7

2. BOUNDARIES AND THE LAW IN AFRIGA 9 Anthony Allott

3. THE STUDY OF BOUNDARIES AND BOUNDARY DISPUTES

Sven Tägil

4. THE EGONOMICS OF THE BOUNDARIES IN WEST, GENTRAL AND EAST AFRIGA

Knud Erik Svendsen

5. THE ORGANIZATION OF AFRIGAN UNITY AND AFRICAN BOUNDARIES

Samuel Chime

6. THE FOREIGN AND MILITARY POLITICS OF AFRIGAN BOUNDARY PROBLEMS

I. William Zartman

7. THE SOURGES OF STATUS QUO AND IRREDENTIST POLICIES

Saadia Touval

8. THE "SOUTHERN BORDER" OF AFRIGA Kenneth W. Grundy

9. INTER-AFRICAN ECONOMIC CO-OPERATION I6I Jokica Hadži-Vasileva 
IO. GOLONIALISM AND TERRITORIAL GONFLIGTS IN AFRICA: SOME COMMENTS

Anat. A. Gromyko

I I. SOME AFRIGAN BOUNDARY PROBLEMS:

A DISGUSSION

Carl Gösta Widstrand

12. APPENDIX I. INTER-AFRIGAN BOUNDARY DISPUTES:

A List and a Map compiled by Robert Waters

APPENDIX 2. THE LENGTH AND STATUS OF INTERNATIONAL BOUNDARIES IN AFRICA: $\quad$ I 86 A List compiled by Anthony S. Reiner

I3. GONTRIBUTORS

I4. NOTES 


\section{Preface}

The Scandinavian Institute of African Studies was established at Uppsala in 1962. Its main purpose is to provide information on developments in Africa to official institutions and private organizations in Scandinavia.

Once a year the Institute arranges an international seminar on contemporary African problems. These seminars are organized in order to provide opportunities for Scandinavian experts and research workers in this special field to listen to and discuss their problems with foreign specialists and to acquire information, new ideas and a widened perspective.

The problem of boundaries in Africa is the subject of a growing, if unco-ordinated body of literature. Until recently, these boundaries were considered to be arbitrary dividing lines imposed by colonial powers and of little relevance to the most immediate problem of nation-building from the centre. Students of African affairs have now begun to investigate the social and political consequences of these often unmarked borders, which divide ethnic and cultural units as well as states.

Recent conflicts, such as the disputes over the boundaries between Morocco and Algeria or the Somalia-Kenya and Somalia-Ethiopia border disputes, have brought the problems of bordes to the fore, and the long-drawn-out Nigerian conflict and recent political developments in connection with the recognition of Biafra as a separate state by some African states has sparked off a discussion on one of the central political ideas of the Organization of African Unity.

Southern Africa is a place with its own dynamics, which, apart from the interior tragical developments, also creates problems for the neighbouring states. Thus, the problem of the "Southern Border" may be considered a special but very relevant complex of boundary problems.

These were some of the ideas which led us at the Scandi- 
navian Institute of African Studies to organize a seminar on African boundary problems. But there was also another important idea in our minds. A common complaint about research carried out in Africa is that the research worker disappears with his notes to some university in Europe or North America and that the results of his findings are never made known in the country in which his field-work was carried out. Another complaint is that research workers do not carry out research that "meets the needs of the country".

Sometimes these complaints are based on an unrealistic assessment of the immediate, short-term application of some types of research results; sometimes-and perhaps more oftenthey are based on a badly felt need of almost any kind of basic facts, analyses and research results on which planning (micro- or macro-) or even administrative decisions can be based. The plea for research that meets the needs of the country is a pretty strong one in Africa, whether the research meets long-term or short-term needs.

Research into boundary problems and the study of the various forces that operate in boundary or territorial conflicts is a kind of research that meets the needs of any country or could at least be adapted to meet them. It is our hope that the papers presented at this seminar will show that this particular type of study can shed light on certain problems common to many African countries.

It is also a pleasure to thank the Nordic Committee for Co-operation in the Study of International Politics including Peace and Conflict and the International Institute for Peace and Conflict Research for granting financial assistance for a seminar, which, as far as I have been able to discover, was the first truly international conference on African boundaries since the Berlin Treaty Conference in $1884-85$.

Carl Gösta Widstrand

Uppsala, May 1968 


\section{A. Allott}

\section{Boundaries and the Law in Africa}

I must confess to a certain difficulty over the English language as regards the definition of a boundary. I am not satisfied with any existing attempts to make distinctions between boundaries and frontiers, such as the distinction between a boundary, which is a line, and a frontier, which is a border zone. Certainly this does not correspond to legal usage. To my mind, all boundaries are imaginary lines which define an area or a territory; they may or may not have been demarcated on the ground or, in other words, reduced to a visible boundary. A frontier is a boundary at which inter-state functions are applied. That is the first point to which I would like to draw your attention: the difficulty in deciding what we are talking about.

The second problem relates to boundary disputes. Without going into the details of the subject, I feel that one can very easily lose one's way in a discussion on political problems in Africa, minority problems, territorial disputes, imperialism, etc. What we should be talking about is boundary disputes, not territorial disputes; in other words, disputes about boundaries, about where the line is to be drawn. It is quite true that, as a consequence of a territorial dispute or a dispute over a minority, a re-drawing of a boundary may be required, but this is a secondary consequence of that particular dispute.

My object in presenting this paper is not so much to offer solutions to the various boundary problems which have developed or may develop between African states, as to point out some of the main legal considerations which have affected the creation of boundaries, the legal context within which they have been imposed, the problems to which some of them now give rise, and the extent to which they relate to pre-existing indigenous notions. 


\section{Indigenous notions}

I begin with a brief consideration of indigenous ideas on the boundaries of political or social units. This I do for two reasons. (i) It may be suggested that the notion of political boundaries exactly demarcated on the ground is a novel one, introduced into Africa by the European colonial powers, along with other exotic notions, such as that of the state or of written legal systems. (ii) Since many boundaries, or at least the territories enclosed by them, were originally acquired by the colonial powers as a result of treaties or agreements with African rulers, it is necessary to consider what area of territory was passed by such agreements, and whether one can say that its extent was precisely defined, either in the minds of the alleged grantor or in the document, if any, recording the agreement.

Where there were nomadic, transhumant or other peripatetic populations (for example, associated with shifting cultivation), it may seem that no specific territory would have been claimed by such groups. Ethnographic evidence from societies like the Bushman and Masai, however, suggests that this analysis would be unjustified. Each group tended to claim a specific area within which to carry on the business of living-hunting, grazing and so on. Sometimes this area might be defined by natural features, sometimes it might be less precise; sometimes it might be extended through the creation of "spheres of influence" or by hostile raids on neighbouring communities. But the main proposition seems secure, namely, that territory is a fundamental conception with traditional African societies, as with modern western states.

Within a given indigenous community internal boundaries may be necessary to separate the areas of exploitation of neighbouring lineages, villages or other local groups. My experience has been that in any area where there is no shortage of occupable land a sort of no-man's-land is left between neighbouring communities. As population increases or the demand for exploitable land develops, this no-man's-land is gradually brought into effective occupation. As and when a more precisely defined boundary of separation is needed, this almost 
inevitably follows a natural feature, such as a river, though it is by no means always the case that nature has conveniently provided a suitable feature in the right place. Sometimes all that can be done is to define boundaries by imaginary lines drawn between conspicuous objects, such as large rocks or trees.

If and when boundaries are demarcated in customary law, whether between neighbouring individuals, families or local communities, the principle that the neighbours should be brought in and made aware of the demarcation at the time is usually followed.

It is often stated that in many of the traditional centralized societies authority was primarily defined by reference to persons rather than territory. This is largely true. On the other hand, the subjects in question occupied territory and in consequence the rulers would claim jurisdiction over it. Many societies, for instance, required settlers from a different community to obtain the permission of the local land authority before settling in the territory of a community to which they did not belong. The notion, therefore, that jurisdiction was personal needs some qualification.

\section{The legal significance of boundaries}

It is useful to consider why we have boundaries and what their legal purposes are. Their legal and administrative functions can be collected under two main headings, which are respectively positive and negative.

(i) Positive functions. If asked, one would say that the primary function of boundaries was to define the limits of governmental authority, as exercised in a given state or political unit. Governments claim to control and perform acts of administration in the territory within the state frontiers. The nature of such control and of such acts varies enormously with the physical and political circumstances, of course. But this is not all: the frontiers define, though not in an exclusive manner, the nationality of those born or living within them. However unimportant this notion may have been in traditional society, nationality has today become one of the primary personal 
characteristics of the individual. Very often the same nationality defines the system of personal law to which the individual will be subjected.

(ii) Negative functions. On the negative side boundaries are mainly exclusionary and define the area from which other authorities and peoples will be excluded, unless they have the permission of the controlling authority. It is worth reminding ourselves, without pursuing the matter here, that boundaries do not necessarily define economic units, "nations" or networks of communication.

Applying these aspects to the African situation, we realise that one of the main problems is the assertion of control and governmental administration in some of the outlying territories which fall within the national frontiers. We also realize that, with a newly developed, indeed underdeveloped, feeling of nationality in many of the African states, one of the main props of the state-boundary systems cannot be depended upon. Many authors have commented on the artificiality of African boundaries. One must remember that all boundaries are artificial, even those which are linked to natural features, in so far as they represent a transcendental and invisible expression of power. The historical argument has also been used to support the accusation of artificiality in Africa, citing the wellknown fact that cultural communities were divided, and unrelated groups combined, by colonial frontiers. This is, of course, not unique to Africa: the boundaries between continental European states might equally be criticized on these grounds, though it is true that many African boundaries are geometrical and thus proclaim their artificiality more evidently.

I would add an additional word to stress the significance of boundaries in defining the extent of application of legal systems in Africa. Since the continent, taken as a whole, does not form a coherent legal community of which the various legal systems are component parts with a fundamental similarity one with the other, the function of boundaries is more divisive, so far as legal systems are concerned, than in, say, South America, where most of the states adhere to the civillaw system. African legal systems are a heterogeneous collec- 
tion of laws taken not only from Europe but from Asia and elsewhere, so that, even if one ignores the variety introduced by local customary laws, a journey across the map of Africa reveals frequent and abrupt changes from one legal régime to the next. This can particularly shock our sensibilities because different imported laws were applied to peoples who were often ethnically connected and all of them had little, if any, real relationship with the traditional cultures of the area.

\section{The legal sources of boundaries in Africa}

To understand how African boundaries developed it is, of course, necessary to examine African colonial history, notably, though not exclusively, the late-nineteenth-century scramble for Africa and the effect of the Berlin Treaty of $188_{4}$. The rivalry of the European powers, and especially of the English and the French, led to exaggerated claims over territory which were often unsupported by effective occupation or even by precise delimitation of the areas so claimed. The hardening of spheres of influence into protectorates and colonies and the transformation of a protective role into a colonial one necessarily involved both a more complete administration and a more precise assertion of sovereignty.

It is unfortunate that a general discussion of boundaries in international legal relations is often confused (often misleadingly) with a discussion of modes of acquisition of territory. Sometimes a claim to territory involves a precise claim to given boundaries; sometimes boundary definition has been a subsequent exercise and one may be able legitimately to distinguish between the claim to the territory and the claim to the boundaries which define it. One may distinguish the following modes of acquisition of territory and definition of boundaries so far as Africa is concerned: (i) treaties and agreements, (ii) conquest, and (iii) usage.

(i) Treaties and agreements. Many colonial claims to territory rested on treaties or agreements with indigenous rulers. Although these primarily granted either political rights of administration or economic rights of exploitation over the territory of the indigenous ruler, they often formed one of the 
major justifications for the assertion of boundaries defining these areas. Although European powers happily relied on such agreements to assert their own claims to territory as against other European powers, they were at the same time quite prepared to argue that these were not real treaties and therefore they themselves could not treat them in the same way as treaties with other states. As so often happens, international law appears to have followed the facts and to have developed doctrines which very conveniently suited the book of the expansionist colonising powers. It seems, however, that neither before nor after the main period of European colonial acquisition in Africa have these arguments been accepted by international-law experts. The notion that these agreements with indigenous rulers were not treaties, because (i) treaties could only be made between states which formed part of the international legal community, and (ii) these societies were not such states, is being progressively discredited, with the realisation that many of them could be called states even in a narrow western sense and that in any case the dichotomy was false. We may assume therefore that such treaties and agreements were, so far as capacity is concerned, of significance in international law. Such treaties have, however, been criticised also on the ground that sometimes the rulers entering into them had no authority in their own law to do so and that, even if they had, they did not comprehend or give assent to the dispositions in the treaties relied on by the European contracting parties, such as the total assignment of administrative authority to the colonial power. Much research is required to check the accuracy or otherwise of these criticisms as they apply to particular treaties, but it is quite clear that $(a)$ individual rulers did purport to act in a manner unjustified by customary law as a result of the blandishments or show of force of the European negotiators, and $(b)$ in any event the total cession of sovereignty might be unprecedented and unprovided for in local customary law. In either case the agreement would have been void and unconstitutional from the customary-law point of view. On the other hand, African legal history is full of cases in which the indigenous ruler of a community has, voluntarily or otherwise, put himself and his 
community under the jurisdiction of a more powerful neighbour: the extension of the various West African empires, such as that of Ashanti, may be cited as illustrations. It would, therefore, be erroneous to argue that such transactions were in all cases inconceivable and illegal under the customary law.

There was the further complication in some instances that the agreements were made by private individuals or chartered companies rather than by their governments.

It is not enough to show that territory was originally acquired and defined by agreements made by the then colonising powers. Continuity of title must be demonstrated or an alternative source of justification adduced for the present holding of territory by the independent African states. This raises the question of state succession and of the transmission of the benefits and burdens of treaties from the colonial power to its successor state. Many of the treaties and agreements upon which claims to African boundaries have been based were not made between the European power, on the one hand, and an African ruler, on the other, but between two of the European powers. This has naturally led to objections by independent African states, who have, however, adopted an ambivalent attitude in the matter. Some of them at certain times argue that it was not competent for European powers to dispose of and divide African peoples without their consent; at other times they claim the benefit of such treaties in support of territorial claims which they wish to make against their neighbours. Whatever one's doubts, looking backwards, about the morality of these transactions, there is little doubt about their nominal legality in international law.

(ii) Conquest and occupation. In reality many African territories were acquired by conquest or by occupation, the agreements being no more than devices to facilitate peaceful occupation. The notion that many of these lands were in international law unoccupied, since they were only in the occupation of primitive inhabitants having no organised state structure, has long been exploded.

In the result, acquisition of territory must either have been voluntary or compulsory. If the so-called treaties are worth- 
less in international law, then acquisition must have been by conquest, usage or sufferance. One of the main problems is to determine what acts of administration constitute effective occupation, and how far occupation of a part of a territory can be said to support and define a claim to a much larger area of adjacent territory. This has been particularly the case in Africa, where European powers who had barely penetrated the interior erected enormous quadrilateral territories based on the coastline, which was in their effective occupation.

(iii) Usage and sufferance. As I have already remarked, one should distinguish between the acquisition of territory, on the one hand, and the precise delimitation of its boundaries, on the other. Where there was not a convention between neighbouring territories or powers, one may say that boundaries have developed through usage and sufferance. Often in consequence they may have been duly delimited verbally and/or defined or demarcated physically only at a later stage. In particular, note the doctrine of prescription as applied to claims to territory.

\section{State succession and boundaries}

The problems of state succession, as they affect former colonial territories, are too vast for me to deal with adequately now, but one must note that international law seems to have come round to the notion that colonial territories which attain independence may be deemed to succeed to many of the rights and burdens which attached to the predecessor colonial power. On the other hand, in recent times ex-colonial countries appear to have been moving towards the position that they will not be bound by treaty obligations incurred by the colonial ruler, unless the independent state specifically adopts or accepts transmission of such obligations. This presents difficult problems, as regards both bilateral and multilateral treaties and conventions. Clearly such a doctrine, as put forward by various African countries such as Tanzania, threatens the stability of boundaries, which of all treaty obligations are perhaps those most open to challenge. This negative attitude towards treaties made during the colonial period is, however, 
balanced by the strong interest of contemporary African states in the preservation of the status quo. This latter notion was expressed in its strongest form in the international-law doctrine of uti possidetis, which was borrowed from Roman law and followed in post-colonial Latin America. The basic principle was that the existing state of affairs should be preserved, whether its origin was lawful or not. A similar doctrine has been adopted by the O.A.U. in its well-known resolution of July 1964 , which "solemnly declares that all Member States pledge themselves to respect the borders existing on their achievement of national independence". It is one thing, however, to declare respect for the border; it is another thing to determine where it runs. Many African boundaries may only have been loosely delimited (i.e. defined by verbal means) and not demarcated (i.e. laid down on the ground by physical means).

A continuing problem with the emergence of new states in Africa is the up-grading in many instances of what were previously only internal administrative boundaries to the status of international ones. The boundaries of the former Frenchspeaking West African states are illustrative of this. It is likely that less care has been taken to delimit, and no arrangement at all to demarcate, such administrative boundaries during the colonial period.

\section{Special boundary problems}

(i) Maritime boundaries. I have seen very little discussion as yet of this problem as it affects African states. The coastline of Africa is relatively free from indentations, and thus the problems which exist in defining the seaward boundaries of countries with heavily indented coastlines, such as Norway and Britain, have not arisen. On the other hand, the definition of territorial waters is at present in a state of flux, and the shift from a three-mile rule to a twelve-mile rule, which appears to be under way, is by no means complete. The exploitation of the natural resources to be found in the sea and in the sea-bed immediately adjacent to the land territory of a state is, however, an important problem for African coun- 
tries, especially in view of the exploitation of oil resources which has either already developed or is likely to develop in the near future (compare Nigeria and the Sudan). There are also the problems of inshore fisheries and the control of the movements of hostile vessels. I gather from geographers that Africa has a relatively truncated continental shelf, and, so far as I am aware, no African country has made the extravagant claims to maritime boundaries which have been made by some South American states (for example, Chile-20o miles).

(ii) International rivers and lakes as boundaries. International rivers as such (for example, the Niger, the Nile or the Congo) in any event give rise to many legal problems, for example, in defining rights of navigation and exploitation. Where, in addition, they are used as international boundaries, further difficulties may occur. So far as I know, there has been no study as yet of this problem as it affects Africa. Difficulties include the definition of which part of the river is to be taken as the boundary, and the effect of changes of course of one sort or another.

(iii) Landlocked states. This is a special problem for Africa, which has a higher proportion of such states than any other continent (14 in all). This incidence is the result of the accidents of occupation, coupled with the lack of forethought of the colonial powers in constructing viable states. Although this question has been tackled at global level, there may be further scope for discussion in an African context of these problems, and of the possibility of procuring special access agreements or servitudes for the benefit of landlocked states.

(iv) Air space. This problem is little discussed as yet, but is highly relevant when it comes to preventing the passage of the aircraft of unpopular powers over the national territory.

\section{Legal machinery for settlement of boundary disputes}

The best way of settling these disputes is, of course, to try and prevent their arising in the first instance, by ensuring that boundaries are properly and acceptably delimited and where 
necessary demarcated. The general demarcation of boundaries in Africa would, however, be enormously costly and quite unjustifiable. Nor does demarcation prevent what are in essence political and territorial disputes, for example, claims to territory occupied by persons of the same ethnic origin as the citizens of the claimant state. Several pairs of African countries have established joint boundary-demarcation commissions to attempt to settle disputed boundaries. The Sudan, for instance, has been involved in such exercises with Chad and Ethiopia.

The alternative is to call in a third party as arbitrator or conciliator. Latin American states have by treaty sometimes invoked the assistance of the Sovereign of Great Britain, but it is clearly unlikely that a similar arrangement would be adopted by contemporary African states. A reference to an international body, whether the International Court of Justice or the O.A.U., is a more acceptable and workable alternative. In the current suspicious atmosphere which boundary and territorial disputes engender in Africa, one can probably hope for no more than mediation, rather than adjudication or arbitration, in boundary questions, but it may be that new interAfrican legal machinery of a more effective kind is now required.

\section{The political significance of boundary questions}

There are various degrees of significance which may attacn to a boundary dispute. At the least there may be the inconvenience due to uncertainty about the exact location of a boundary, which can, however, be amicably settled by the two states. More serious disputes, still overtly and essentially concerned only with the location of a disputed boundary, may arise. But, to my mind, the most important aspect to boundary disputes is that they are and will continue to be a handy weapon available to any state which wishes to pick a quarrel with its' neighbour. This technique, which was fully exploited by Hitler, has not yet been employed in Africa, but the escalation of tensions, for example, between the Sudan and Ethiopia, might have the effect, at some time in the future, of 
inducing one or other of the parties to resort to this device. In the long term, boundary disputes may become of less significance, but in the short term, that is, for the next 25 years or so, frontier problems may arise all over the continent. The fact that there is little activity at the moment is no indication whatsoever that it may not occur in the future. There is the possibility, by no means remote, that the redrawing of one international frontier may lead, on a sort of domino system, to an expanding effort to re-draw the frontiers within the continent. The Balkans have often been used as the source of an opprobious epithet to describe the carving up of Africa: a study of the map of eastern Europe in 1914, 1938 and 1968 will show that balkanisation can include re-balkanisation or debalkanisation.

\section{Reduction by legal means of the significance of boundaries}

Rather than settling disputes or preventing their arising by demarcating boundaries, is it possible to make them unnecessary? This leads to questions outside the scope of this paper, such as the setting up of economic communities, but one aspect which is within my terms of reference is that of the possibility of harmonization or unification of laws.

One of the main consequences of the drawing of a boundary is that it leads to the application on either side of the frontier of a different system of law. In Africa very often that means an entirely different system, for example, one based on the English law and one on the French law. Is it possible to foresee any reduction in the significance in this kind of legal frontier between the legal systems through harmonization or unification of laws?

This is a vast field, little explored up to now in the African context. It seems likely that a better effect may be achieved in miniature by inter-African conventions on specific points or purposes only for uniform treatment of a given topic, such as inter-territorial migration or inter-territorial taxation. I do not see much prospect in the immediate future of much being achieved by the introduction of a new pan-African law. 
I should like to end with one suggestion and one question:

(i) We need a new map of Africa, a new survey of the map of Africa from the boundary point of view, which would bring Hertslet (Map of Africa by Treaty) up to date by recording the more recent agreements, and also a survey of the existing boundaries, to see how far they are demarcated in theory and even more important how far these demarcations have survived in practice.

(ii) Supposing we were given the map of Africa and, ignoring all colonialism, the historical past, Berlin Congresses and so on, given a free hand to re-draw the boundaries of the map of Africa to-day so that the boundaries would become not artificial and arbitrary but natural and acceptable, what on earth would the map of Africa to-day look like? Could one possibly achieve such a goal? 


\section{The Study of Boundaries and Boundary Disputes}

The problems of international boundaries are studied in several different fields of scholarship. A geographer's main interest is perhaps the relation between boundary lines and various geographical elements, but it can also be the boundaries' influence on, for example, society and the economy. A lawyer specialising in international law may concentrate on the interpretation of international agreements for the regulation of boundaries. The historian studies individual boundary disputes, preferably along a time axis, while the political scientist may analyse present-day boundary problems, possibly in a synchronous context. The problems of boundaries are attacked from many angles, methods differ and the end-products are of varying value.

The foremost purpose of this lecture is to draw attention to some general features of international boundaries, features which may give rise to conflict and features which may restrain or avert conflict. The points of view which $I$ put forward are partly based on my experience from an inter-faculty research project which is in progress at the Institute of History at Lund and which is studying the relation between conflict and state and national boundaries. The research project, which is still in the first stage of development, is not a "historical" project in the usual sense of the word, but has a wider aim, which is to reach certain general conclusions, though within a defined time and geographical framework. The aims could be described as extending to the so-called middle-range theories.

Since boundaries and boundary problems can be studied from so many different angles, it is not surprising that many 
different suggestions have been made for the classification of boundaries. Wittermore Boggs' classical work, International Boundaries (1940), suggested a system of classification with four main types, though all with further subsidiary divisions. Boggs speaks of:

(1) Physical boundaries, which follow a particular natural feature, such as a range of mountains, a watercourse, a desert area, etc.

(2) Geometric boundaries, that is to say, straight lines, arcs of a circle, meridian boundaries and suchlike.

(3) Anthropo-geographical boundaries, which are related to various features of human settlement and culture, for example, linguistic, economic, cultural and historical boundaries. In this category should be included national boundaries (the problem is to define them, but I shall return to that further on).

(4) Compounded boundaries, which are defined as compromises between the various basic types. ${ }^{1}$

This phenomenological classification system has decided advantages if one wants to study the stability and instability of different types of boundaries. For other purposes, of course, a more "historical" classification may be more practical. Norman Pounds (1963) classifies boundaries according to the cultural development in the borderland at the time when the boundary was drawn. He mentions:

(1) Antecedent boundaries. Here the boundary is drawn before the development of the cultural landscape.

(2) Subsequent boundaries. The boundary has been drawn after the development of the cultural landscape and follows cultural boundary lines.

(3) Superimposed boundaries. In this case, the boundary has been drawn after the development of the cultural landscape but without regard to possible cultural boundaries.

(4) Relict boundaries. These are boundaries which can still be seen in the cultural landscape, even though they no longer have any function of political division. ${ }^{2}$

Both these classification systems-the first phenomenological, the second sequential-have proved practical for analyses of the way in which boundaries create or avert conflict. On 
the other hand, there is little reason to take into consideration what has long been the most common division into "natural" and "artificial" boundaries. The expression "natural boundary" has too many connotations, gives incorrect associations and has a far too variable content and significance during different periods. Since every boundary divides people and not geographical units, all boundaries must in one sense be considered artificial.

A study of the way in which boundaries create or avert conflict naturally involves focusing attention on border disputes. This expression must also be defined more precisely. The concept of "conflict" must be interpreted relatively widely. It cannot be restricted solely to open conflict-in which violence occurs in one form or another-but must also include conditions with varying degrees of tension. The work must be directed at measuring the stability of the boundary at different times, always trying to get as exact measurements as possible of this stability. The investigation must, therefore, be arranged on a time axis. The furthest points of the scale are, at one end, open conflict and, at the other end, complete acceptance, on different political levels, of the boundary.

The definition of the term "boundary conflict", as it is used here, can be expressed as follows: "A boundary conflict exists when the territorial ambitions of at least two parties are irreconcilable."

A boundary dispute is not, however, always identical with a dispute over territory, even though, conversely, most territorial conflicts also inyolve boundary problems. The territorial conquest of an entire state, for example, cannot reasonably be counted as a boundary dispute, since the result is instead the elimination of a boundary. Geopolitics in its entirety can also be excluded from today's scientific debate on boundary disputes.

It is, of course, possible to define the concept of boundary dispute even more precisely. Prescott (1965) gives the following four main types:

(1) Territorial disputes, which result from some quality of the borderland which makes it attractive to the state initiating the dispute; 
(2) Positional disputes, which concern the actual location of the boundary, and usually involve a controversy over interpreting the delimitation or description of the boundary;

(3) Functional disputes, which concern state functions applied to the boundary;

(4) Disputes over resource development. The territorial dispute has an aim to change the position of the boundary; the last two types do not have as their aims to change the location of the boundary. ${ }^{3}$

One main problem in the study of boundary disputes is the actual identification. What is cause and what is symptom? In many cases, the boundary problem is not of primary importance in a dispute, even though propaganda and political argumentation try to claim the opposite. It is naturally quite possible for a government to use the boundary question as a pretext for starting a conflict, when the primary reasons are perhaps on a quite different level. There have even been scholars who have considered that the problem is fictitious. According to this theory, all boundary disputes are caused by the state interest and all arguments put forward are merely pretexts. The geopoliticians argued in this way in their time. The theory cannot be upheld, however. Empirical investigations show clearly that boundaries can in themselves give rise to conflict.

One way of approaching this problem seems to be by the method already mentioned, of studying the boundary during a fixed period along a stability axis. The stability or instability of the boundary is decided by the degree of acceptance at certain political levels on both sides of the boundary. The term "acceptance" is intended to indicate the documented opinion of specified groups of the boundary line as just, reasonable, functional and so on.

In the project on which I am engaged at present-and which has been concentrated on Central-European boundaries during the period between the World Wars-it has proved practical to direct the investigation of the degree of acceptance to six political levels:

(1) State A's central government,

(2) State A's organ for boundary policy, 
(3) A national minority within state $B$, but identifying itself with the people of state A,

(4) State B's central government,

(5) State B's organ for boundary policy.

(6) A national minority within state A, but identifying itself with the people of state $B$.

This analysis pattern is useful for Central Europe during the period 1918-39. For other periods and other environments the model will probably have to be modified. The point is, however, that it should be possible to analyse the attitude to the boundary of those making the decisions on different political levels. Complete stability can be said to exist in the case in which the boundary line is accepted on all levels, both local and central. The analysis pattern also makes it possible to attack the problem of the extent to which boundary problems are primary or secondary factors in a larger conflict.

How can one then proceed, purely practically, when one wants to investigate the stability of an international boundary within this defined sector? We have started by collecting data on the changes made in the boundary during a specific period, that is, roughly the boundary's "history". We have also tried to collect data on the changes in the boundary between different peoples-the "national frontier"-during the same period. One can, for example, measure changes in the ownership of the land. One can study the minorities' voting figures. One important sector in this connection is the school system. To which national type of school do the border people send their children? One can also ask: which newspapers do the border people read? To put it briefly, the most important point is to investigate the national preferences, as expressed in specific choice situations, when the border people are forced to choose between two alternatives, either $X$ or $Y$.

After treating the data on possible changes in the state boundary and taking measurements of possible displacements in the population boundary, we confront these variables with each other and with the measurements we get by content analysis of acceptance of the boundary line on political levels.

The possibilities mentioned above of measuring changes in 
the boundary between peoples lead on to the very difficult question of nationality. To start with, it is important not to get confused by the fact that the term "nation" is often not kept separate from the idea of "state" in common linguistic usage. A nation is not the same thing as a national state. "Nation" describes an ethnic population group. The problem arises first when we have to decide which criterion shall apply for membership of a nation and the classification of nations.

National sentiment can be said to be an expression of a feeling of solidarity and a desire for solidarity with a larger group of people, which is limited in certain respects and which has certain characteristic common features. Quincy Wright has described this as a state of opinion." But what then are the factors which produce this feeling of solidarity?

Language is perhaps the most obvious outward sign of such a community feeling. But only in some cases. The rule does not apply to all parts of the world and not during all periods. There are many examples of how a common language does not lead to a feeling of national solidarity. There are also cases in which a feeling of national solidarity has developed despite different languages. Especially in the border regions, the language boundary and the national boundary often show a remarkable lack of agreement.

Common traditions can also be of importance. Quincy Wright speaks of the importance of common symbols.5

One significant point in this connection is that national sentiment does not have a fixed magnitude for all time. It can be weakened, but it can also be influenced, activated or given an entirely new direction. This is the main prerequisite for all boundary policy-the conscious policy aimed at changing the national structure in a border region. Many of the established national states have been produced by such measures; either loyalty has been induced by a common outer framework or else such a common framework has been dispersed by the creation of group loyalties.

Karl W. Deutsch has a functional definition of nationality and peoples. By nationality, he means a people striving to gain control over its members. By peoples, he means larger groups of individuals who are bound together by certain com- 
plementary habits and characteristics, that is to say, by a standardised system of symbols-language, customs, history-in other words, all the components which can be included in the vague idea of culture. ${ }^{6}$

The question of national solidarity is especially important in the border regions. The state boundaries are seldom "pure" boundaries, and since it is possible to influence the sense of nationality, the boundary between people can also be moved, so that its agreement with the state boundary becomes either greater or less. In the cases in which there are national minorities in the border regions, the implied problems become even more accentuated.

Among the factors which make a state boundary unstable, great importance must obviously be assigned to the national minorities. We also know from experience that politicians often see the national minorities within their own states as sources of unrest and a de-stabilising factor. This has led to governments trying by different means to reduce these centres of unrest, either by trying to assimilate the foreign part of the population-which often has the opposite effect, however-or by meeting the minorities' demands on certain points, in order to reduce the group's interest in pursuing an irredentist policy.

The current idea is that national minorities have a de-stabilising effect when they occur in large units near a state boundary. 7 There are also cases, however, in which the presence of national minorities has been a stabilising factor on a state boundary. This can apply to the situation in which there are two minorities of about equal strength, one on each side of the boundary. This is because the boundary policy of both states has to be modified, since negative repercussions may otherwise afflict their own minority groups. This can in favourable cases lead to a certain reciprocity in the boundary policies of both parties, which in its turn can have a stabilising effect on the existent state boundary.

The minority's striving for a boundary change can seldom be materialised without support from the mother people with whom the minority identifies itself. But an interaction often occurs between, on the one hand, the central government's 
boundary policy, and, on the other, the detached minority. Socalled dynamic minorities are in many cases functions of an active boundary policy in the mother country. Here I must once again draw attention to the difference between primary and secondary boundary disputes. A state which is willing to make an armed attack in order to change a boundary may have an interest in alleging the wishes of a sympathetic minority in the neighbouring country. It is then often claimed that the minority in question has been subjected to discrimination or oppression. The analysis pattern mentioned earlier makes it possible, however, to reveal how much is the minorities' own original feeling and how much is the policy of the state taking action.

Thus, a lack' of national homogeneity in border regions means in certain cases-though far from all-a tendency to instability of the state boundary.

Politicians often use another complementary type of argument when demanding a change of boundaries-the "historical" argument. They say either that their own people have been the first settlers in a desirable region or that the region in question has earlier belonged to their own country or their own royal house or something similar. Historically developed, united regions can in such cases be used as a pretext for not letting a state boundary coincide with a national boundary.

I shall only mention a few of the most important other factors which can have a de-stabilising influence on a state boundary. First, there are the economic factors. A territorial expansion may, for one thing, often have an economic background. A state boundary may also have a very restrictive effect economically, on the border population's trade, for example, and this may naturally lead to increased tension at the boundary and increased discontent among the border population. But if economic arguments are put forward in a boundary dispute, this means, according to Prescott, that economic integration already exists across the boundary. ${ }^{8}$ Problems of this kind can, however, be solved through changes in the prevailing boundary functions, questions which it should normally be possible to solve by negotiation. The boundary functions do not, though, usually in themselves give rise to 
conflict but can rather be regarded as symptoms of the respective states' attitudes to each other.

The boudary functions must naturally be taken into consideration in an analysis pattern for boundary disputes. In our investigations we shall try to construct a kind of scale to show the boundary's significance. Or, to put it more simply, what does it mean in reality for a person to live by the boundary?

Related to the economic factors are those connected with exploitation of natural resources, and especially any which cut across the existing state boundaries. In this context it may also happen that demands are made for the right to use the other state's territory for transport, which in some cases may be of significance for the boundary functions.

During certain periods of history, strategic reasons have obviously weighed heavily when boundaries were drawn. Political security has been said to necessitate the moving of a boundary or the creation of buffer states. This kind of argument was not uncommon in the period between the World Wars and was bound up with the military and technical developments at that time.

Positional disputes--the last of Prescott's four main types of boundary dispute-have only played a minor part during modern times, as far as Europe is concerned. In other parts of the world, for example, South America, however, the situation is obviously different.

Prescott's division of boundary disputes into four main types -territorial disputes, positional disputes, functional disputes and disputes over exploitation-are thus significant for the analysis of every boundary dispute. On the other hand, this systematisation naturally does not mean that a boundary dispute can only be characterised as belonging to one of the categories. A combination of two or more types is, of course, quite conceivable.

Much less attention has so far been paid to factors which have a direct stabilising effect on a boundary. Removal of the de-stabilising factors does not, after all, in itself necassarily guarantee that the bondary will become more stable. In some cases, adjustment of a boundary can, of course, give greater homogeneity and stability to the boundary in one re- 
spect but at the same time have exactly the opposite effect in another respect. A closer agreement between the state and the national boundaries may perhaps create increased problems in, for example, economic or strategic contexts.

The most important stabilising factor seems to be time. ${ }^{9}$ The longer a boundary can remain undisturbed, the greater the chance that it will remain stable. And conversely, the newest boundaries often appear to be the most unstable. One need not go far to find the reason. The longer a boundary has existed, the greater is the interction between the boderland and the rest of the county, and the greater the integration. More and more threads bind the borderland to the central region, through the administration, communications, economy and so on. The country's homegeneity increases. The strength of the central government is, of course, very important for this process.

So instability should be at its greatest before such homogeneity has had time to develop. As I pointed out earlier, national factors are especially difficult to deal with in a border region, particularly when there are rather important national minorities. Therefore, it cannot be considered surprising if a central government should in various ways try to reduce the effect of this de-stabilising factor. If the minorities are relatively small and above all geographically dispersed, the result can be an assimilation. As I mentioned before, however, too severe measures on the part of the central authorities can have exactly the opposite effect, especially in cases where the minority is supported by its mother country.

The difficulties involved in bringing stability to a border region in such cases have, in certain extreme examples, led to radical solutions of the population-resettlement type, known from, for example, eastern Europe during the Nazi period.

Boundary policy and boundary disputes have played a prominent part in European history, especially between the two World Wars, when so many new boundaries were drawn and an overheated nationalistic climate prevailed. There are two points, however, which it is important to remember about the most topical boundary problems today. None of the factors which create conflict are generally valid during all periods of history and in all environments. The aim of the boundary 
project on which we are working in Lund at present is, as I said earlier, to investigate under what conditions boundaries create or avert conflict within certain structures and periods. That is not to say that we shall reject the possibility of making comparisons between, for example, boundary problems in Europe between the World Wars and in Africa today.

When we originally started the project, we thought that within peace and conflict research we should be able to find ready-made theories on how boundaries give rise to conflict. We found, however, that there was no applicable theory which could serve as the basis of our work of testing historical data. We are admittedly going to try the method and material used by Lewis F. Richardson in Statistics of Deadly Quarrels, in order, for example, to illuminate the correlation between a boundary's length and the number of wars, or between the number of boundaries and the number of wars. But I do not think that one can be satisfied with the result of that kind of investigation alone.10 We had greater expectations, at the start, of Kenneth Boulding's theory of spatial competition, which he originally took from the economic field but which also, according to Boulding, can be assumed to apply to conduct between states, 11 The viability theory assumes that one can work out a system for measuring the strength of states, something which must be regarded as highly problematic. In an unpublished investigation, Lars Niléhn, who has made a critical study of Boulding's theory of viability, puts forward the opinion that not even the central theory can be used as an explanatory model.12 Despite this, however, attempts will be made to test Boulding's theory on a small scale on some historical source-material.

Thus, the research project on the qualities in state boundaries and national boundaries which create or avert conflict has not yet yielded any definite answers to the questions put. My presentation of it now has aimed at systematising the problems and pointing out possible ways of tackling them in a purposeful way. It is obvious that the problems of international boundaries cannot be compressed into a few simple formulas. It is equally obvious that there are many central research tasks to be found within this field. 


\section{The Economics of the Boundaries in West, Central and East Africa}

The network of boundaries has left West, Central and East Africa with a large number of states-in all 25 new political units, from Mauritania in the northwest over the Central African Republic to the United Republic of Tanzania in the southeast. Many present and past political leaders from this and other parts of the continent have stressed and urged the importance of African unity, and since the formation of the new states many efforts of a varied character have been made to realize this political objective.

Over the last couple of years disillusion has been widespread. Despite the many declarations and meetings the results in the political field seem to be few. One after another coup has substituted military-based regimes for civilian leaders, not according to any master plan to bring about unity in this way but as a result of forces internal and external to the many affected states.

Time has still to show whether these changes have removed mutual hostility and suspicion and in general whether they will turn out to have a positive impact on the cause of closer political co-operation. At present interest in the political sphere is on the decline.

Behind this political scene different economic aspects of the boundaries drawn during the colonial scramble for Africa are coming more to the foreground. Independent Africa is in need of a different and more rapid economic development than colonialism could offer. What is the interaction between this expressed need and the frontiers in Africa?

The years 1966,1967 and 1968 have been very rich in terms 
of new or revised forms of inter-state co-operation in the economic field-to what extent do these forms overcome the Procrustean boundaries?

Independence and its many dimensions are still very new to most African countries. It seems important not to forget this simple fact in an assessment of the past few years. In no other group of countries has independence been accompanied and, indeed, even preceded by a stronger call for unity across the boundaries. This is reality as much as the failures are. The hope is still there. Will it be realized through gradually strengthened economic co-operation?

\section{The artificial nature of the boundaries}

At the outbreak of the First World War France, Britain, Germany, Belgium, Portugal, and Spain had carved up West, Central and East Africa between themselves. It is an obvious point that the motives behind this division, or rather the mixture of national action (in terms of the self-interest of the colonial powers) and historical accident, have little, if any, relation to the needs of independent economic development in the second half of the twentieth century. On the other hand, to carry out a hypothetical exercise of defining nonartificial "rational" boundaries in the context of modern economic requirements may be not only very difficult but also unrealistic.

In looking back on the manoeuvres of the colonial powersstill so well remembered in Africa-it is tempting to exaggerate the element of rational economic motives behind what was essentially one of the biggest races in history. The agreement at the Berlin Conference in 1884 that effective occupation was to be a condition for recognition of annexation gave the starting shot for the inward expansion of the relatively small coastal colonies of the European powers (only Belgium had at that time a large chunk of the interior of Africa with a corridor to the sea). The French moved eastwards from Senegal, northeast from Conakry and northwards from Abidjan and Porto Nuovo. The British followed the Gambia River from Bathurst on the coast; they expanded from Sierra Leone 
and the Gold Coast; British trading companies moved up north from the Gulf of Guinea and got the protection of their government. The Germans created Togoland from a narrow coastal strip. In Central Africa the target for the race seemed to be Lake Chad: the French came from the west and south from the northern banks of the Congo river, the British extended present Nigeria to the northeast and the Germans stretched Cameroon up to the lake. In East Africa the Germans expanded from the coast to Lake Tanganyika and Lake Victoria; this was their German East Africa. The British created theirs to the north, together with the protectorate of Uganda. Access to the sea came in this way to be a common feature of all of the possessions (taking the French- and British-dominated territories as a whole). The Belgians showed a flair for exploiting mineral resources in Katanga, and the French seemed more keen on sheer space than the British. Lord Salisbury is quoted as having said of the French Saharan ambitions: "Let the Gallic cock sharpen his spurs on the desert sands!" These ambitions seem to be paying off in the present decade. (One may wonder if it is possible to explain the differences between British and French decolonization by these geopolitical realities.)

The First World War brought the first major amendment to this system of colonial frontiers; territories formerly under German rule were transferred to mandates under the League of Nations. The map of Africa, emerging from this process, showed a large French area in West and Central (Equatorial) Africa, with a few British intrusions here and there, Belgium ruling over the vast Congo colony and finally Britain controlling the three East African territories.

For the use which the colonial powers made of Africa, these boundaries seemed, on the whole, to be fairly well arranged, mainly because of the slow and sporadic economic growth. The Gambia colony was certainly a nuisance to the French; the interior of Guinea and the whole of Upper Volta had to circumvent British territory to get to the sea. The Belgian Congo had its transport problems with regard to the Katanga copper. None of these weaknesses of the boundary system created serious problems in the colonial context. The export pro- 
duction was the major interest of the powers that had arranged the boundaries and nothing indicates that another set of boundaries would have affected this production one way or another. The interest was low transport costs and only in a few cases did the boundaries create minor obstacles; the even distribution of economic activity and its general advance was not a major concern of this form of economic system.

\section{What did independence mean for the boundaries?}

The creation of a series of politically independent states in the late 1950's and in the beginning of the 1960's changed the character, if not the effectiveness, of the boundaries. On each side of them was territory ruled by sovereign states and not by different colonial powers or the same colonial power. National interests were under formation and policies were gradually being formulated which affected the impact of the boundaries.

Superficially this may be presented as a new and deeper division of Africa than the one constituted by large colonial areas under some form of joint administration. As elsewhere, boundaries divide states and therefore they have economic aspects. In Africa the frontiers are obstacles to the potential economic development now, when independence has been gained. In other words, the economic effects of the boundary system must be interpreted in relation to the new political realities in Africa, including the political need for material advance for the young nations, and also including the continued presence of economic interests external to Africa.

This does not mean that the immediate impact of the transformation of the boundaries in creating obstacles to the existing flows of economic activities is unimportant. It would be wrong, however, to spend too much time on deploring this as a special African phenomenon. States use boundaries as a tool in economic policy whether they are located in Europe, North America or Africa, and whether they are in the stage of de- 
veloped industrialization or in a period of economic underdevelopment. In assessing the reaction of the African states to the economic effects of their boundaries, it will be most sensible not to apply an absolutely ideal yardstick, but to keep remembering the behaviour of the European states in relation to their own boundaries. Africa is often burdened with impossible and impatient expectations which tend to hide the small steps forward.

The boundaries in Africa have divided many ethnic groups; at the same time they have created new nationalities and new formal status as citizens of one and only one state. And a state usually treats its own citizens differently from foreigners. In an economic sense these new concepts on the African scene are of importance to the long-established migration of labour which has been and still is a special feature of the labour market in Africa. In West Africa the main movement of people of a seasonal and semi-permanent nature is from north to south, from the states of Mali, Upper Volta and Niger and the northern parts of the coastal countries to the intense agricultural export activities on the coast. The same coastward migration goes from Mali, the western part of Senegal and the northwest of Guinea to coastal Senegal and Gambia. There are also several lateral movements along the coast; it has been estimated that roughly 75 ,ooo every year go from east to west to be groundnut share-croppers, while up to 1 million go south (half in Ghana and half in the Ivory Coast) to work on the cocoa farms. ${ }^{1}$ In Central Africa the movements from territory to territory have always been of less importance and were based on compulsory schemes to get labour from the interior to Gabon's forests; they were also resisted because of differences in diet between the interior and the forest zones. A forest labour force of mixed geographical origin still exist, but the annual flows across state boundaries are small. In East Africa major interstate movements go from Rwanda and Burundi to Uganda and Tanzania and from Malawi to Tanzania.

The fact of independence will, at least in the short run, affect the different forms of migrant labour differently. According to Elliot J. Berg, the movement of unskilled labour in West Africa has not been appreciably affected. In Tan- 
zania the large reduction of the labour force on the sisal estates since the beginning of $1960^{\prime}$ 's has been mainly at the expense of foreign workers. And there can be little doubt that similar situations are bound to arise in time. When national and foreign labourers are competing on the same terms for too few jobs, the new states will give preference to their own citizens. This is true in particular as regards urban employment requiring some degree of training and education. Independence has restricted the opportunities of the Dahomean fonctionnaires to get employment in Senegal and the Ivory Coast. When the heads of state of the Entente (Ivory Coast, Upper Volta, Togo, Dahomey and Niger) in December, 1965, decided to introduce the "double nationality" for citizens of any of their states working in another member state, this met with such strong resistance in the Ivory Coast that the Democratic Party had to postpone the scheme indefinitely. This was the most recent setback for the employment of Dahomians in other Francophone states in Africa. In 1958 they had been persecuted by the population of Abidjan; later Senegal expelled 2,000 Dahomians, followed by Gabon and Congo (Brazzaville). In 1963, after the revolution in Dahomey, Niger expelled the Dahomean government employees, which led to the departure of the entire Dahomean community of 16,000 persons. These nationalist or ethnic tendencies in the manpower policy may only get stronger, if a better balance is not established between the demand for and the supply of educated manpower-and this seems unlikely. Apart from the case of the Dahomeans (and the Ibos in Nigeria), outstanding examples of severe if not complete restriction (or threats of restriction) have occurred in conjunction with inter-state political disagreements; the Ivory Coast in 1959 threatened to expel Mossi migrants from Upper Volta in order to force Upper Volta to withdraw from the Federation of Mali. Ghana has at different times closed and opened its boundaries, while a clash between Gabon and Congo (Brazzaville) in 1967 led to the mutual expulsion of Congolese and Gabonese workers.

Greater concern has been shown with regard to the disruptive effect of independence on inter-African trade flows. Senegal, created to be the administrative and industrial centre 
of French West Africa, found itself cut off from its free access to its former markets. Tanzania was concerned about the dominating position of Kenya-manufactured goods on the Tanzanian market. In both these cases independence immediately created a new situation and the reaction to this will be discussed together with the overall problem of economic cooperation between independent African states. Otherwise it may be worthwhile to underline that the well-established flows of cattle, fish and other food products-what may be called traditional trade-still goes on almost unhampered by the existence of boundaries. This mostly unregistered trade is one of the outstanding examples of a natural division of labour in Africa. It may raise problems in a future pattern of co-operation, but at present it goes on as usual.

It is, of course, difficult to maintain an effective border control along many of the long African boundaries. And smuggling is a common feature. Gambia is popularly said to have two resources-groundnuts and contraband goods to be sold in Senegal. Different national price policies on cocoa in West Africa and maize and paddy in East Africa must lead to smuggling to high price zones. The Ghana Chamber of Commerce complains about smuggling after the devaluation of the new cedi etc.

Independence made the boundaries more efficient; it erected customs walls and other barriers to trade and migration. Independence had an immediate effect on the form of unity which colonialism had imposed on Africa. Of far greater impact than this are the future economic consequences of the mosaic of states-and their different external links with Europe-which has been the end-product of colonization. It may be useful to remember that the break-up of French West Africa (AOF) and French Equatorial Africa (AEF) was prepared in advance by the delegation of more powers to the individual territories by the French government.

The basic economic question is therefore how the system of boundaries inherited from colonialism has interacted with the speed and form of economic development in Africa in the few years since independence and how it will interact in the years to come. 


\section{The economic dimensions of boundaries in West and Central Africa}

Colonialism and independence have up to now created 22 states in West and Central Africa. Most of them are small and large at the same time-small in population numbers and total income, large in area. Of the 22 countries, few had less than 1 million inhabitants, three between 1 and 2 million, and nine between 2 and 4 million, i.e. in all 16 with less than 4 million people. Of the remaining six countries, three had populations ranging between 4 and 6 million. This leaves us with three major states: Ghana with 7.7 million; Congo (Kinshasa) with $15^{-16}$ million, and Nigeria with more than 45 million (official estimate 57.5 million) (Table 1 ).

These predominantly small states turn into micro-states as soon as one attempts to measure the size of their internal markets. Table 1 offers the available statistics on total production in these countries (gross domestic product) in 1965 or the nearest year. It is common knowledge that figures of this nature must be used with great caution. The non-marketed part of the total production in African countries is very large $(20-40 \%)$ and can only be estimated very approximately; the monetary part of the gross domestic product is also assessed with great uncertainty; the conversion of production figures in national currencies to U.S. dollars according to the official exchange rates is a dubious exercise. However, the information still shows with sufficient precision that we are dealing with very small internal markets. This result is obvious, as we are combining low population figures with the fact of low per capita income in Africa.

Comparing these figures with the production figures for Scandinavia (Denmark, Norway and Sweden), we find that the 19 states (with less than 6 million inhabitants each) with a total population of $5^{0}$ million had a total production of approximately 5,500 million dollars or approximately one-fifth of the total production of the 16 million people living in Scandinavia. It is an inescapable conclusion that these states are micro-markets, corresponding to the purchasing power of European towns with less than 200,000 inhabitants. The figures 
become even smaller if we restrict ourselves to the market for industrial goods (only $20-30 \%$ of total income).

The only national markets of reasonable size are Ghana (because of a high per capita income) and Nigeria (because of her large population).

The economic consequence of these simple facts is as simple as it is strong, namely, that the development of these countries will depend on their participation in an international division of labour. Autarchic policies are absurd in this context and similarly it is meaningless to expect any real fall in their total exports and imports relative to their total production (at present $25-40 \%$ ). If these countries wish to develop, they will be forced to trade and co-operate in other ways with other countries. In this sense they are more economically dependent than the countries of Latin America and Asia.

As I said above, some of these states are at the same time large in area. This gives them very low population densities and one can call them "low-density markets", as their total production per square kilometre is small (see Table 1 ).

The two density figures are, however, very misleading, as many of the countries have a very uneven spread of population. In Chad almost half of the population live on $10 \%$ of the land in the south and a similar southern orientation is found in Niger, Upper Volta, Mali and to a lesser extent in the coastal states of West Africa. Considering both the urban and the rural population, West and Central Africa today consist of a few high-density population clusters on different parts of the coast, in southern Upper Volta and Niger, in northern Nigeria, in the interior and northern parts of Cameroon, around Kinshasa and in Katanga.

Nigeria stands apart, not primarily because of its size (five of the other states have a larger area) but rather because of the fact that it has heavy population concentrations, both on the coast (in particular in the east) and in the northern parts, with a middle belt of a population density more typical of West Africa as a whole. Ivory Coast, Ghana and Upper Volta together would have formed a similar, but much smaller unit.

The same dispersal is found in the location of present-day agricultural activities. Hance, Kotschar and Peterec have pre- 
pared a very useful map of the source areas of exports from tropical Africa, showing intensive productive "islands" along the coast, in the west of Mali, in the Senegal River basin, in northern Nigeria (stretching into southern Niger) and in the interior of Cameroon and Congo (Brazzaville), and less intense areas in the southwest of Chad and the northeast of the Central African Republic, to the north and in the centre of the Congo (Kinshasa).

It is interesting to note that only very few of these areas are cut by existing state boundaries. Their locations seem to have been determined by natural factors and the low rate of colonial development, and much research is needed to find potentially productive areas, at present neglected.

The industrial map reveals a few industrial centres (excluding extractive industry, which by its very nature is heavily localized). In Francophone West Africa there are two major industrial poles in Dakar and Abidjan, and some of less importance in Conakry, Bamako, Niamey, etc. In Anglophone West Africa we find similar bases in Accra-Tema, Lagos, Ibadan, Kano, and Port Harcourt. In Central Africa these major poles are Kinshasa and Kisangani in the Congo and DoulaEdea in Cameroon, while Pointe Noire and Brazzaville constitute minor centres of industrial activity.

This dispersed and polarized nature of production in West and Central Africa makes economic development very dependent on the availability and the costs of transportation. Nature and climate make both road and rail transport very expensive for the interior. The capitals of the landlocked states are in most cases more than 600 kilometres from the coast.

The differences in location of the 22 states are maybe of greater economic importance than their differences in market size and density. The system of boundaries has created two types of states: the coastal and the interior states. This, combined with the fact of natural zones running east-west has resulted in the landlocked states standing in the second rank, not only in relation to the coast but also in terms of natural productivity and therefore in income per capita (future discoveries of minerals in the large landlocked areas may reverse the last relation). The differences among these states 
are indeed striking. Countries like Ghana, Senegal and Ivory Coast have per capita incomes 3-4 times as great as Nigeria (as a whole), Mali, Upper Volta, Dahomey, Chad, Togo, Central African Republic, and the Congo (Kinshasa) (Table 1). And these are differences felt and understood in the states themselves.

The division of the states into Francophone and Anglophone has similarly had a long-lasting economic impact on African development. The trade and financial involvement of these two groups of countries differ greatly and their differences in administration and elite culture also tend to divide them. Whatever name the presence of differing external interests is given, it is crucial to an understanding of African economic affairs. France is yielding slowly in relative shares of trade, contracts and finance to other EEC countries (in particular, West Germany) and the U.S.A. are showing a growing political interest in Africa; all these and other states are active on the African scene, influencing the policies of the young and small states.

This combination of a colonial boundary system with external factors must be seen in conjunction with the difficult structural problems of the African economies. They are strongly export-oriented agricultural systems, with few processing and manufacturing industries. They are extremely short of development skills of a technical and administrative nature. Many of them are financially weak, with heavy pressures on their current budgets; all of them rely to a large extent on foreign finance for their development investments, and basic research into their natural resources originates from abroad.

A narrow economic analysis of the effect of the boundary system on development is, therefore, not possible. It has to be an exercise in "political economy". As we shall see, there are many arguments for economic co-operation in terms of production costs and material benefits, stability and economic independence, but the ideals of co-operation have to be combined with an understanding (not recognition) of political realities in order to work out an operational strategy composed of steps to be taken, not only in the long run but also in 
the ever-present short run.

Put in another way, it is not sufficient to state in economic terms what ought to happen; the changes to be reasonably expected must also be outlined. Normative and predictive efforts must go together.

In such an endeavour the economist, with his limited tools of costs, benefits, structure and growth potential, is at a loss. How do the existing political patterns in these parts of Africa stand in relation to the question of economic co-operation? Are the present and future decision-makers inside and outside Africa in a position, in which their interests or behaviour will lead to more co-operation; if the answer is yes, of which type?

There has been a tendency in much of the literature and most of the political speeches to present unity as depending solely on the pure will of the leaders. A corollary of this has been the attempts to remove or counteract state leaders who do not subscribe to special versions of African unity. This seems to be a thing of the past, as renewed inter-African contacts are apparently based on the principle of non-interference, accepting the diversity of economic and political policies in the different states. In which sense will economic necessities more and more force the leaders, other local power groups and the external factors to embark on schemes of co-operation, maybe only because of their interest in maintaining and strengthening their own positions? Is it possible to point to conflicts or disagreements concerning the form, speed and content of co-operation across the boundaries?

Some of these questions will be tentatively answered in the following analysis of the experiences of East Africa, followed by a presentation of the more general arguments for and the basis of economic co-operation in Africa, and finally a discussion on the problems of inter-state economic relations in West and Central Africa. 
Economic co-operation across the boundaries in East Africa

The three East African countries, Kenya, Tanzania and Uganda, in many ways present a different picture from the West and Central African states. In fact it might be argued that they represent a very special case of African co-operation based on certain unique advantages at the time of independence.

In per capita income they are not very different from the typical West African country. They are similarly export-oriented economies with predominantly agricultural sectors. As political entities they are, however, fairly large in terms of market size. The group has a total population of close to $30 \mathrm{mil}-$ lion people, which, taken together with their lower average income, gives a total production somewhat larger than Ghana (meaning that their market density is lower than the Ghanaian one). Despite all their differences, which account, as we shall see, for much of their mutual discussions, they are fairly equal compared with the West and Central African countries. To put it in another way, the country with the lowest average income has a much larger population and therefore constitutes a large market for its two partners.

From a transport viewpoint the population distribution is not the most fortunate. There is a heavy concentration of people around Lake Victoria and in the Kenya highlands, but the Tanzanian population is scattered around the periphery of the country, just as there is a rather long distance between the coast of Kenya and its population clusters up-contry. In Tanzania the south has weak economic links with the rest of the country and similarly its West Lake region has easier access to Uganda than to Mwanza on the southern shore of Lake Victoria.

At independence, however, some of the basic transport questions were solved, linking the Tanzanian parts of the Lake area and northern Tanzania with the two other countries. Under colonialism and in the first years of independent rule a relatively high degree of economic integration was obtained. The countries were de facto members of a customs union and 
the inter-East African trade was very large by African standards. Of their total exports, a large share was inter-East African $(16 \%$ in 1961 , and $17 \%$ in 1966$)$-similar figures for West and Central Africa are lower than $10 \%$ (adjusted for unregistered trade). Again manufactured goods represented a larger share of their internal trade than was normal in West and Central Africa. East Africa was more than a customs union; it was rather a common market with free movements of capital (a common currency), common services (railways, harbours, airways) and common East African political institutions.

For some years there had been close contacts between the political leaders of the countries and the educated elite had to a large extent obtained their higher education at one institution, Makerere College in Uganda.

The three countries in these and other ways had good opportunities to develop new forms of co-operation, when independence came. Changes in their relationship had to be expected, as the new co-operation had to serve a new rationale, namely, to link three independent states, each pursuing its own interests. Many aspects of the East African co-operation which had evolved under colonialism did not meet the requirements of an equal partnership but had been created to serve and protect the white Kenyan interests.

It is not surprising that it was Tanzania, and not Kenya, which urged changes in her own interest. She saw herselfin the words of President Nyerere-as the common market for Kenya and Uganda, while her exports to the two other countries were low (in 1963 she exported goods to the value of 68.5 million shillings to the other two countries, while Uganda exported goods worth 164.8 million shillings and Kenya 395.8 million shillings to the other two countries in East Africa).

The inter-territorial trade was, in other words, unbalanced. Even though trade deficits and surpluses in customs unions are far from perfect measures of losses and gains on account of the mutual concessions of customs-free entry, they still indicate a certain unequal distribution of advantages. In the political discussions in Tanzania these trade figures were long accepted as good indicators of the imbalance of the co-operation. 
Of political importance was also the fact that Nairobi had firmly established itself as the major industrial and administrative centre in East Africa, with many expanding factories and with head offices controlling companies in the two other countries. It was feared by many that a free location of industries in East Africa within the framework of a customs union would lead to a further concentration of industrial activities in Nairobi.

Before independence this problem of the uneven distribution of the benefits of the customs union had obtained a certain recognition, as a distributable pool had been formed in 1961. This pool received a fixed share of company taxes and customs and excise duties, and this made Kenya the biggest contributor; half of its income went to the joint East African administration and the other half was divided equally between the three countries. The total effect was a fiscal redistribution from Kenya to Tanzania and Uganda, but the amounts were not considered by political circles in Tanzania to be very large.

Tentative calculations of cost and revenues from the three national parts of the railways also show a certain transfer or subsidy from Kenya to Tanzania.

In general it may be said that the decision-makers in Tanzania were not interested in fiscal transfers, at least not of the magnitude involved. The loss of customs revenue because of the customs union has never been in the foreground of their argumentation. Maybe this is due to the less desperate fiscal situation of Tanzania, compared with many West and Central African states.

When all three states had become independent, an attempt was made to remedy the industrial imbalance in the region by the Kampala Agreement of April 1964. Firms established in all countries were asked to move more of their production to countries with a deficit in the inter-East African trade and a small number of industries were allocated among the countries. The allocation list was so short that Kenya only received one of the new industries and consequently she never ratified the agreement. Neither was the clause about an industrial committee to study further allocation ever implemented. Meanwhile a combination of tendencies in Tanzania to go 
it alone and to teach Kenya her dependence on access to the Tanzanian market produced a series of restrictions against imports from Kenya in 1965 , and several Tanzanian firms were quick to exploit this new protection. The break-up of the common currency in 1966 would probably have come whatever happened to the common market.

A ministerial commission on East African co-operation set up by the three governments started its work at the end of 1965. In June 1967 the three heads of state signed the Treaty for East African Co-operation, which came into force on December 1 st, 1967 . The solutions embodied in this treaty will be tested in the coming years.

There are four major elements. (1) The customs union is preserved, but under certain conditions a country may impose a so-called transfer tax on imports from its partners to the maximum of $50 \%$ of the external tariff and for only up to 8 years (under present circumstances Tanzania may use the tax against both its partners, Uganda against Kenya and Kenya not at all). (2) An East African Development Bank is established to promote industrial expansion; $38.75 \%$ of its capital must be invested in Tanzania and Uganda respectively and the remaining 22.5 in Kenya. (3) The headquarters of the common institutions will be transferred from Nairobi to Kampala, Dar es Salaam and Arusha (in Tanzania) and the national composition of their staffs will be made more equal. (4) New East African authorities will be formed, including the posting of one minister from each country to the headquarters of the community in Arusha. There will continue to be a legislative assembly with members elected by each of the national parliaments.

In short, the three countries grant each other certain preferences in trade but not the completely free access of a full customs union. Through this and the operation of the Development Bank, it is hoped that a better industrial and overall balance will be struck.

Discussions among economists in Tanzania show a certain concern about the effectiveness of the transfer tax and the Bank in securing more of the future East African industries for Tanzania and in avoiding the duplication of plants which 
would destroy the rationale of the common market. It has been suggested that industries on this scale will need more protection than is offered at present by the external tariff for intermediate and capital goods; as changes in this common tariff must be agreed upon by all three partners, negotiations of this nature must consider the location of the new plants.

In general, it cannot be said that the treaty excludes further bargaining between the three states, and the community headquarters and the Development Bank' will have to be greatly strengthened, so that they can take the initiative in making proposals to ensure that the real condition for the success of the treaty, namely, a fairly even distribution of industrial advantages, is realized.

It is in the interest of the three governments to establish close economic co-operation, in order to bring about a higher rate of economic growth in the region as a whole and in each of their countries than would be possible without preferential access to the whole East African market. They have by now gained enough experience in industrial development to know that more and more of their coming industries will need markets larger than each of the national incomes, in order to have sufficiently low production costs. But Tanzania can be expected to follow the operation of the new system very attentively. Because of this, it is important to find better measures of the distribution of the benefits among the countries than the indications given by the trade figures. In this respect, also, much depends on the common institutions.

As we know, the three countries pursue different development strategies. This difference was given new emphasis by the nationalisations in Tanzania in February, 1967 . However, the socialist policy of Tanzania does not in any way reduce its need to participate in an international division of labour with its neighbours. This point is worth noting in relation to similar differences in West and Central Africa. In 1968 it is probably clear to all states of a socialist orientation in these parts of Africa that dedication to socialism does not offer international advantages in terms of trade and assistance which can be substitutes for inter-African co-operation.

During the vicissitudes of East African relations in the last 
few years the influence of international organisations, of large trade and financial partners and of foreign professional economists has been almost completely in favour of continued co-operation. That this had to be so can be understood by the simple fact of the high degree of integration already existing in East Africa at independence.

It is far too early to discuss the questions raised by the interest in joining the community shown by many neighbouring countries (Ethiopia, Somalia, Zambia, etc.). A widening of the community to include states which at present have few economic and transport links with East Africa will raise many complicated problems for a treaty which has not completed its first year. With the present political situation in Rhodesia, and considering the active Tanzanian-Zambian-Chinese efforts to build a railroad through Tanzania into Zambia, the latter country appears to be the most important entrant.

\section{Economic integration in Africa: General arguments and problems}

Before turning to the situation in West and Central Africa, it may be useful to draw some lessons from East Africa and to state the general case for integration among developing countries. Normally, five partially overlapping arguments are advanced in favour of integration: (1) it will enable developing countries with small internal markets to achieve economies of scale from larger industrial units producing for amalgamated markets; (2) it will further specialization between countries, in some cases exploiting different natural and other advantages of the co-operating countries; (3) by creating larger markets, it may in time allow for the existence of more and hopefully competing industries and thereby enhance efficiency; (4) larger markets may be more diversified in structure and therefore less vulnerable to external fluctuations; (5) integration may increase the bargaining power of the developing countries. ${ }^{3}$

The basic problem of East Africa has been-and to a large extent still is-the inability of simple trade liberalization, for 
example, in the form of a customs union, to ensure the equitable distribution (in particular, of industrial development) apparently desired by weaker members of customs unions in Africa. All member countries of a customs union are given equally free access to the larger market; for many reasons, historical, natural and locational, however, they are not able to exploit these opportunities to the same degree. Even though they may all be better off than without the customs union, which is not by any means agreed, they certainly do not share the benefits in an equitable manner, and as a rule, it is easier to demonstrate the latter than the former point to the political decision-makers.

In East Africa, as elsewhere, the operational question has logically been to regulate or supplement trade liberalization in such a way that it becomes acceptable to all partners. The countries may grant each other different degrees of preferential treatment relative to non-member trade partners (the transfer tax and the conditions for its use form a device of this kind). Joint ventures of a financial or productive nature (common development banks, common transport services, joint river-basin development, etc.) may help to redistribute some of the benefits of the measures of trade liberalization. Direct fiscal redistribution may also be practised. On the institutional side the gradual growth of supranational decision groups may also advance the cause of integration, including its most advanced form, co-ordinated or joint development planning, not yet practised even in a rudimentary form in East Africa.

The question of time is crucial. With time the advantages and need for co-operation become greater and at the same time more obvious to the political leaders, whose experience in independent development is still very short in Africa. The national economic cadres and industrial interests are also young, and their advocacy of integration with its many political aspects may be more important than the most competent international advice (in this sense both the O.A.U. and the United Nations Economic Commission for Africa and the East African Community at this stage are very much weaker than the national centres). 


\section{Integration in West and Central Africa}

A quick glance will reveal a bewildering number of interstate unions and organisations in West and Central Africa; many of them seem to rest on shaky foundations and seem not to produce any real measures. However, since 1966 the efforts to create more effective links have become more evident. And from mid-1968 the impact on inter-African co-operation of the association of 18 states with the European Economic Community will be tested through the negotiations for a renewal of the Yaoundé convention.

Fourteen African states belong to the Common Organisation of African States and Madagascar (OCAM) and the Economic Commission for Africa has been very active in trying to get 14 West African states to join a West African Economic Community. As a starting-point in getting a grasp of the major problems of economic magnitudes, it may, however, be more convenient to compare the nature of the smaller groupings, before discussing the existing forms of integration and its future problems.

In West and Central Africa we find several existing or potential economic units. The Entente covers five states (Ivory Coast, Upper Volta, Togo, Dahomey and Niger) and the Organisation of Senegal River States (OERS) covers four (Mauritania, Senegal, Mali and Guinea). Seven of these belong to the West African Monetary Union (UMOA) in the franc zone (Mauritania, Senegal, Ivory Coast, Upper Volta, Togo, Dahomey, and Niger) and these seven, with Mali substituted for Togo, form the West African Customs Union (UEAO), while Mali aspires to become a member of the UMOA. Between four states (Guinea, Ivory Coast, Liberia and Sierra Leone) there is a barely existing free-trade association. In Central Africa we find the Economic and Customs Union of Central Africa (UDEAC) with Cameroon, Gabon, Congo (Brazzaville), Chad and the Central African Republic, but the decision of the latter two in April 1968 to form a Union of Central African States (UEAC), together with Congo (Kinshasa), has made the present and future of the UDEAC uncertain (see Table 2).

We may get an impression of the size and nature of these 
groupings from Table 1 . The most striking fact is that the total production of each of them (excluding the UDEAO and UMOA) and therefore their markets appear to be smaller than the markets of Nigeria and East Africa, respectively. And the production of Ghana is of the same size as that of the largest grouping, namely, the Entente (considering the significant difference in per capita income between the two, Ghana's market for industrial goods is larger). Secondly, the relative position of the members of these groupings is very unequal (and thus different from the situation in East Africa). The Ivory Coast represents roughly half of the total production of the Entente, Senegal provides similarly more than half of the production of the OERS, Cameroon almost half of the output in the UDEAC (and more than half of the production of Cameroon, Gabon and Congo (Brazzaville) taken together) and finally Congo (Kinshasa) accounts for almost three-quarters of the gross domestic product of the new UEAC.

These relative shares are, of course, not perfect indicators of the uneven distribution of economic and political power in the groupings; on the whole, the smaller partners are made even weaker by their landlocked location. Looking at the industrial leaders, we find that Cameroon, Ivory Coast and Senegal have total incomes smaller than Kenya, while Ghana (and, of course, Nigeria) have larger internal markets than Kenya.

What can we conclude from all this? To take the case of Ghana first, its relatively large internal market does not make its need for future integration smaller than Kenya's. It has probably advanced further in substituting local production for imported manufactured goods and therefore it is closer to the end of the easy phase of industrialization, namely, import substitution on the national scale. The same point can be made for Senegal, Ivory Coast and Cameroon; if they want to industrialize further, they will have to look for markets.

The less developed partners of these groupings are in a much weaker position than Tanzania in East Africa, because they are so small and most of them depend on transport investments in the other member countries (in general, their 
problem is distance). Leaving all political, historical and geographical considerations aside, it would be possible to create a very large market with low internal (sea) transport costs by joining Senegal, Ivory Coast, Ghana and Cameroon in a union of equals with a total market $25 \%$ larger than Nigeria and more than $50 \%$ larger than East Africa.

The $O C A M$ is a loose organisation of 14 Francophone countries for joint consultation. It has managed to arrange a common market for sugar for the benefit of Madagascar and Congo (Brazzaville) and is committed to organizing arrangements for meat. It has been active in the formation of the African and Malagasy Coffee Organisation (OAMC), similar unions of development banks and post and telecommunication services, Air Afrique, etc. Its charter contains no commitments regarding trade barriers.

The West African Customs Union was established in 1959 with a programme of trade liberalization. In $\mathbf{1 9 6 6}$, after several years of regression of economic co-operation in the group, the old treaty was replaced by a new one. The agreement provides for a common external tariff (not yet established) with a triple column, i.e. a minimum tariff for most-favoured nations and a general tariff, three times as high, for other countries, but other indirect taxes are not covered by the agreement. The members of the Union offer each other preferential treatment; total taxation on intra-Union imports is, in principle, to be equal to $50 \%$ of the total fiscal burden on similar imports from third countries paying the lowest import taxes, i.e. the other members of the franc zone and the EEC, which are exempt from customs duties. However, this percentage may be raised to $70 \%$ for protective purposes, and quantitive restrictions on trade within the Union, which are ruled out in principle, may be imposed by individual members in order to cope with an economic imbalance. ${ }^{4}$

The Entente was created in 1959 with the Ivory Coast and Upper Volta as members; Niger, Dahomey, and Togo joined later (Togo in 1966). From the beginning it has aimed at a complete customs union and common communication services and in 1966 a solidarity fund was changed into a solidarity and loan-guarantee fund with an initial capital of 5 million 
dollars, of which the Ivory Coast has paid four-fifths (at the same time agreeing not to accept payments from the fund for the first 5 years). This fund gives priority to two-or-morecountry projects, and in December 1962 it granted 1.2 million dollars to a textile plant in Niger (in equity and long-term loan). The countries have set up a committee for the production and distribution of meat. Ghana has attended a recent transport co-ordination meeting of the Entente.

The Organisation of Senegal River States (OERS) was formed in 1968 , as a continuation of the Inter-State Committee for the Senegal River, which after its formation in 1963 and assistance from the United Nations Development Programme in 1967 entered into a financial commitment of 3 million dollars for the construction of a dam at Gouina; commitments of this nature will be divided among the members according to the benefits they receive from the individual projects. In 1965 the four heads of states decided to propose a regional grouping of the whole of West Africa and empowered the President of Mauritania to take the necessary steps; at the same time they decided to create a sub-regional group of the four and invited the secretary-general of the Inter-State Committee to draft the statutes. In March 1968, the OERS was born with its own institutions (including an advisory parliamentary council with five members from each state and an executive secretary, and three general secretaries for the three fields of activity: the development of the river basin, planning and development in general and educational, cultural and social affairs).

The EC $A$ has been active for many years to bring all West African countries together in an economic community. At a meeting in Niamey in October 1966, the representatives of all the countries recommended to their governments the setting up in 1967 of inter-governmental machinery for economic cooperation, and an interim ministerial committee has been formed. The council met in Monrovia in April 1968 with no representation from the Entente Countries. In January 1968, the President of Niger, acting as President of the OCAM, underlined the difficulties of this broader co-operation but pointed to possible fields of co-operation: campaigns against epidemics, transport programmes and bilingual education. 
The Central African Customs Union (UDEAG) entered into force on January 1st, 1966, when Cameroon joined the Equatorial Customs Union (UDE), which had existed since 1959. A common external tariff for all items was agreed upon, and there is a common central bank (in the franc zone, as in West Africa). A part of the customs duties was to be paid into a fund to compensate the inland countries for their loss in customs revenue. The members agreed upon a procedure for advance consultation in regard to the establishment of industries exporting to the regional market, on a "taxe unique" levied at the factory exit for an agreed list of enterprises (exporting to other members of the customs union) and redistributed according to the share of products consumed by each country. In December 1967, the five heads of state met and decided on harmonization of legislation and fiscal matters; their ministers of economic affairs were asked to meet in June 1968 to work out an equitable industrialization programme for the Union; the use of the solidarity fund for 1968 was agreed upon.

On the surface the Union seemed to prosper, but at the beginning of 1968 it was heard that the two landlocked members were not content. In March 1968 a Union of the States of Central Africa (UEAC) was announced with Congo (Kinshasa), Chad and the Central African Republic as partners, and a charter was signed by the three heads of state on April 2nd, 1968. According to this charter, a common external tariff for the three countries will be established, all internal customs duties, and import and export taxes will be abolished and the movement of persons, services and capital will be free. Investment legislation will be introduced, favouring the landlocked members, and the charter establishes an investment and compensation fund.

Few details about the reasons for the break-up of the UDEAC are available. The President of the Central African Republic has announced that the Congo (Kinshasa) will provide the Republic with 5,000 tons of cement per year at the same price as in the interior of the Congo, and the payment will go to a special fund of the UEAC. According to this information, European cement cost 6,00o francs c.i.f. per ton at 
Pointe Noire, while it cost 22,00o francs c.i.f. in Bangui and $5^{2,000}$ francs ci.f. in Fort Lamey. The Foreign Minister of Chad has in the same way stated that the purpose of the new Union is exclusively to give the two interior countries a real permanent opening to the sea, which the UDEAC, despite its three harbours, was not able to offer.

Besides these economic motives, the Congo (Kinshasa) may also see the new Union as a strengthening of its political position in Africa. The UDEAC is now defunct and its three members must re-consider their mutual co-operation; in view of the fact that Chad and the Central African constitute small and distant markets, the loss caused by their departure cannot be very great.

The efforts at integration meet many difficulties in West and Central Africa. To the problems of acute smallness of national markets, uneven size and stage of development of the individual countries, differences in colonial past and therefore present administration and language and many instances of open political conflicts between the states must be added the strong economic and political presence of the EEC and France in the area.

The partnership between the EEC and its 18 associates in Africa is of a very special nature. Here we have a group of six developed countries wanting to get preferential access to the markets in Africa (and trying to share these advantages more equally between their own business communities) by extending certain preferences to the African associates (while maintaining agricultural protection and subvention schemes in Europe), together with a package of multilateral financial assistance from a special development fund and substantial bilateral assistance from France and to an increasing degree from West Germany. This very direct combination of trade preferences and aid schemes is, of course, of a dangerous nature. Moreover the aid philosophy of the EEC members seems to be monolithic in favour of the promotion of private enterprise.

The Secretariat of the ECA has time and again-maybe less and less in the last year or so-expressed its concern that this special relationship between the EEC and its associates may 
separate them from their more natural partners in Africa. At the second UN Conference on Trade and Development the associates would not give up the advantages the EEC offers them in support of the campaign of the developing countries to obtain non-reciprocal general trade preferences. In view of the hazy character of the second Conference it seems difficult to blame the associates for taking this standpoint.

As has transpired from the preparations for the Monrovia meeting in April 1968, the Francophone countries at the same time are afraid that the stronger industrial poles of Ghana and Nigeria may reap the major benefits of a full and unregulated West African customs union.

The negotiations between the EEC and the African associates which are to begin in June 1968 are going to be extremely interesting to follow. At the meeting of the heads of states of the OCAM in January, 1968 (with observers from Morocco, Tunis, Nigeria and Ghana) it was decided to set up a scheme of close joint consultation between the associates, and the African countries have stressed that the present EEC arrangements have in no way solved their major economic problem, the falling prices of their export products.

For its part the EEC Commission published in 1967 a study of the possibilities of industrialization in the West African and Central African states. A series of new industrial enterprises, mainly in the field of consumer goods (but also including cement) with a total investment of approximately 120 million dollars and the employment of nearly 10,000 people in $3^{1}$ enterprises has been suggested for West Africa (most of them in Dakar and Abidjan). For the UDEAC area 19 projects with an investment of approximately $5^{\circ}$ million dollars have been suggested, and for the Congo (Kinshasa) 15 enterprises with a total investment of approximately 6o million dollars. Apparently the EEC experts and private firms accept the need for industrialization and therefore larger markets. The old concept of an Eurafrique, an industrial-raw-material partnership, may have been replaced by a more modern need to develop the African markets (it is obvious that industrialization in Africa will not reduce but increase its imports of manufactured goods). At the same time no attempt seems to have been made 
to consider the inclusion of Sierra Leone, Liberia and Ghana in these industrialization schemes.

\section{African boundaries under economic pressure}

In only one economic sense can boundaries be taken as absolutes: they demarcate the area and location of a state. This dimension of boundaries in Africa is certainly of great importance, as has been shown in recent years by the rapid expansion of the extractive industries in West and Central African countries (but not-yet?-in East Africa) and by the existence of a number of economically small landlocked states. However, it is true to say that the main point about the economics of boundaries is that they are of varying degrees, constituting different kinds of obstacles to the free movement of goods, persons and capital. In their demarcation of state territories they also constitute necessary conditions for the formation of politically and economically integrated nations, and the thickening of the border lines in Africa has definitely served to foster more unification and sense of purpose in depth than colonialism could ever have offered.

As we have seen above, the boundary system in West, Central and East Africa is of a character which, with the exception of Nigeria-problematic as an integrated unit-has created a series of small developing countries. There are, therefore, strong theoretical arguments-assuming economic development as a desirable goal-for an economic "loosening" of the boundaries. Experience shows that the efforts to increase economic co-operation and thereby reduce the economic impact of the boundaries, at least in some directions, have grown and become more serious lately. It is difficult to see any forms of resistance to this which would be rational in relation to any set of interests (elitist, parasitical, popular, foreign, etc.). This does not exclude the fact of conflicting interests about the forms and geographical extension of this co-operation, in particular in relation to West Africa. This region has become the victim of an inherited division into Francophone and Anglophone countries. And for Africa as a whole the strength of the division into EEC associates and non-associates will soon 
be exposed to a real test. In other words, some boundaries are for these reasons "taller" than others.

In the short run the economic pressure on the boundaries may only lead to the formation of small groupings of Francophone countries, which would create problems in particular for Ghana and Sierra Leone (assuming that both Guinea and Mali become more and more acceptable to their neighboursand France). Ghana is, however, already now a fairly large market (with a high density), which may offer better export prospects for EEC countries than the two Francophone groupings, the Entente and the Senegal River States. It is difficult to see how this basic fact of the size of the Ghanaian market can be prevented from influencing the pattern of economic co-operation. The Francophone fear of the competitiveness of Ghana may lead to a certain hesitation among Francophone countries to let Ghana join a full customs union (in principle, these countries may already give each other different degrees of preference).

Assuming a certain minimum rate of development-needed by the rulers as well as by the ruled, by nationalists as well as by external forces-sooner or later all the economic boundaries will have to change, for even with a maximum rate of growth of, say, $6 \%$ per year, African national markets will still be small markets.

It is the countries with the most dynamic performances (excluding cases of extreme mineral abundance) which will feel the need for a transformation of the boundaries most quickly and most strongly (they will still remain small for many, many years). The poorest and the landlocked states may turn out to constitute the most difficult and unstable components of future co-operation. They insist on an equitable distribution of industries and on the largest share of foreign assistance. How equitable such a distribution may be, without reducing efficiency too much, is going to be a hard question in the negotiations for a transformation of the boundaries.

Finally, it is striking that much of the discussion of a freer flow of goods across the internal boundaries of Africa deals with industrial goods only, just as many agreements on economic co-operation (including the new East African treaty) 
explicitly rule out agricultural products (food). In the field of an international division of labour in agriculture, based on often unknown present and future differences in comparative advantages, most of the international and inter-African organisations have been passive. Attempts to reform the economic impact of boundaries which do not attack this question seem to miss the important point, that food supplies are becoming more and more of a problem to several African states.

Table 1. Population, area and gross domestic product (GDP) in West, Central and East Africa, 1965 .

\begin{tabular}{|c|c|c|c|c|c|c|}
\hline & $\begin{array}{l}\text { Population } \\
\text { mid-1965 } \\
\text { estimate } \\
\text { (1ooos) }\end{array}$ & $\begin{array}{l}\text { Area } \\
\text { (Iooos } \\
\text { of } \mathrm{km}^{2} \text { ) }\end{array}$ & $\begin{array}{l}\text { GDP } \\
\text { at market } \\
\text { prices } \\
\text { 1965 } \\
\text { (millions } \\
\text { of } \$ \text { ) }\end{array}$ & $\begin{array}{l}\text { GDP } \\
\text { per } \\
\text { capita } \\
\$ \$\end{array}$ & $\begin{array}{l}\text { GDP } \\
\text { per } \\
\text { km }^{2}\end{array}$ & $\begin{array}{l}\text { Popu- } \\
\text { lation } \\
\text { per } \\
\mathrm{km}^{2}\end{array}$ \\
\hline \multicolumn{7}{|l|}{ West Africa } \\
\hline \multicolumn{7}{|l|}{ Entente } \\
\hline Ivory Coast & 3,836 & 322 & 1,000 & 260 & 3,100 & 12 \\
\hline Upper Volta & $4,85^{8}$ & 274 & $23^{\circ}$ & 50 & 840 & 18 \\
\hline Togo & I,638 & 57 & 150 & go & 2,600 & 28 \\
\hline Dahomey & 2,365 & II3 & $75^{a}$ & 75 & 1,500 & 21 \\
\hline \multirow[t]{2}{*}{ Niger } & 3,328 & $x, 267$ & $250^{a}$ & 75 & 200 & 3 \\
\hline & 16,025 & 2,033 & 1,805 & Iro & 900 & \\
\hline \multicolumn{7}{|l|}{ OERS } \\
\hline Mauritania & 920 & 1,030 & $150^{a}$ & 160 & 150 & 1 \\
\hline Senegal & 3,490 & 196 & 675 & 190 & 3,400 & 18 \\
\hline Guinea & 3,500 & 246 & $175^{b}$ & 50 & 700 & 14 \\
\hline \multirow[t]{2}{*}{ Mali } & 4,576 & 1,202 & $250^{b}$ & 55 & 210 & 4 \\
\hline & 12,486 & 2,674 & 1,150 & 100 & 470 & \\
\hline Gambia & $33^{\circ}$ & 10 & - & 一 & - & 33 \\
\hline Sierra Leone & 2,290 & 72 & $350^{a}$ & 150 & 5,000 & 32 \\
\hline Liberia & $x, 066$ & I I I & $280^{a}$ & 260 & 2,500 & 10 \\
\hline Ghana & $7,74^{\circ}$ & 229 & $1,700^{\circ}$ & 220 & 7,000 & 32 \\
\hline Nigeria & 57,500 & 924 & $3,200^{c}$ & 55 & 350 & 62 \\
\hline \multicolumn{6}{|l|}{ Cenlral Africa } & \\
\hline Chad & $3,35^{\circ}$ & 1,284 & 240 & 70 & 190 & 3 \\
\hline
\end{tabular}




\begin{tabular}{|c|c|c|c|c|c|c|}
\hline & $\begin{array}{l}\text { Population } \\
\text { mid-1965 } \\
\text { estimate } \\
\text { (10oos) }\end{array}$ & $\begin{array}{l}\text { Area } \\
\text { (Iooos } \\
\left.\text { of } \mathbf{k m}^{2}\right)\end{array}$ & $\begin{array}{l}\text { GDP } \\
\text { at market } \\
\text { prices } \\
\text { I } 965 \\
(\text { millions } \\
\text { of } \$)\end{array}$ & $\begin{array}{l}\text { GDP } \\
\text { per } \\
\text { capita } \\
\quad \$\end{array}$ & $\begin{array}{l}\text { GDP } \\
\text { per } \\
\mathrm{km}^{2}\end{array}$ & $\begin{array}{l}\text { Popu- } \\
\text { lation } \\
\text { per } \\
\text { km }^{2}\end{array}$ \\
\hline \multicolumn{7}{|l|}{ Central } \\
\hline African Rep. & 1,352 & 617 & 160 & 50 & 260 & 2 \\
\hline Cameroon & 5,229 & 475 & $640^{a}$ & 125 & $\mathrm{x}, 35^{\circ}$ & I I \\
\hline Gabon & 463 & 267 & 210 & 450 & 800 & 2 \\
\hline \multicolumn{7}{|l|}{ Congo } \\
\hline \multirow[t]{2}{*}{ (Brazzaville) } & 840 & 342 & $140^{\circ}$ & 170 & 410 & 3 \\
\hline & I I, 234 & 2,945 & 1,390 & r 25 & 470 & 3 \\
\hline \multicolumn{7}{|l|}{ Congo } \\
\hline (Kinshasa) & I 5,627 & 2,345 & $1,000^{d}$ & 65 & - & 7 \\
\hline Rwanda & 3 , I IO & 26 & 一 & - & 一 & 123 \\
\hline Burundi & 3,210 & 28 & 一 & 一 & - & 115 \\
\hline \multicolumn{7}{|l|}{ East Africa } \\
\hline Kenya & 9,363 & $5^{83}$ & 1,000 & I IO & 1,700 & 16 \\
\hline Tanzania & 10.524 & 940 & 730 & 70 & $75^{\circ}$ & II \\
\hline \multirow[t]{2}{*}{ Uganda } & $7,55^{1}$ & 236 & $625^{e}$ & $80^{e}$ & $2,600^{e}$ & 32 \\
\hline & 27,440 & 1,759 & 2,355 & 85 & $\mathrm{r}, 350$ & 16 \\
\hline Zambia & 3,710 & 746 & 600 & 160 & 800 & 5 \\
\hline Malawi & 4,000 & I 19 & 180 & 45 & $\mathbf{I}, 500$ & 33 \\
\hline
\end{tabular}

${ }^{a}$ I $964 . \quad{ }^{b}$ I $962 . \quad{ }^{c}{ }_{1963 .}{ }^{d}$ I $961 .{ }^{e}$ Factor cost.

Sources: IMF, International Financial Statistics, December, 1967. UN, Monthly Bulletin of Statistics, December 1967. OCAM, Bulletin Statistique, No. 7, September, 1967. Samir Amin, Trois expériences africaines de développement. Le Mali, la Guinée et le Ghana, Paris, I965, (for Mali and Guinea).

Table 2. Recent ECA documents on economic co-operation in Africa.

E/CN.14/346. 1o December 1965. Report of the Sub-regional Meeting on Economic Co-operation in East Africa.

E/CN.14/351. 4 May 1966. Report of the Sub-regional Meeting on Economic Co-operation in Central Africa.

E/CN.14/L.320/Rev.1. Report of the ECA Mission on Economic Co-operation in Central Africa (1966). 
E/CN.14/366. 11 November 1966. Report of the Sub-regional Meeting on Economic Co-operation in West Africa (Niamey, 10-22 October 1966).

E/CN.14/386. 13 January 1967. Economic Co-operation in Africa. Present Situation and Proposed Programme of Activities of 1967 1968.

E/CN.14/399. 24 May 1967. Report of the West African Sub-regional Conference on Economic Co-operation (Accra, 27 April to 4 May 1967).

E/CN.14/EA/EC/2 + Add.1. 17 and 28 August 1967. Trade Expansion in Eastern Africa: an Outline for a Programme of Action. Part I and II.

E/CN.14/EA/EC/3. 25 September 1967. Planning and Policy Aspects of Economic Co-operation in East Africa.

E/CN.14/EA/EG/6. 27 September 1967. Situation Report on Industrial Development Co-operation in the Eastern African Subregion.

E/CN.14/EA/EC/ 7 . 3 October 1967 . Notes on Suggested Opportunities for Agricultural Co-operation in the Eastern African Subregion.

E/CN.14/WA/EC/2/Add.1. 9 November 1967. The West African Customs Union (WACU).

E/CN.14/WA/EC/5. 27 October 1967 . Preliminary Draft of a Treaty for the Economic Community of West Africa and Explanatory Notes.

E/CN.14/UNCTAD II/4. 28 December 1967. Economic Co-operation in Africa.

Table 3. Membership of inter-African organisations.

Common African and Malagasy Organisation (OCAM); Senegal, Ivory Coast, Upper Volta, Togo, Dahomey, Niger, Cameroon, Gabon, Congo (Brazzaville), Chad, Central African Republic, Congo (Kinshasa), Rwanda, Madagascar.

West African Economic Community (proposed): Mauritania, Senegal, Guinea, Mali, Ivory Coast, Upper Volta, Togo, Dahomey, Niger, Gambia, Sierra Leone, Liberia, Ghana, Nigeria.

West African Economic and Customs Union (UDEAO): Mauritania, Senegal, Mali, Ivory Coast, Upper Volta, Dahomey, Niger.

West African Monetary Union (UMOA): Mauritania, Senegal, Ivory Coast, Upper Volta, Togo, Dahomey, Niger. 
Organisation of Senegal River States (OERS): Mauritania, Senegal, Mali, Guinea.

Entente: Ivory Coast, Upper Volta, Togo, Dahomey, Niger.

Niger River Commission: Mali, Guinea, Ivory Coast, Upper Volta, Dahomey, Niger, Nigeria, Chad, Cameroon.

Lake Chad Commission: Niger, Nigeria, Chad, Cameroon,

Central African Economic and Gustoms Union (UDEAC) (in suspense): Cameroon, Gabon, Congo (Brazzaville), Chad, Central African Republic.

Central African Monetary Union (UMEA): Cameroon, Gabon, Congo (Brazzaville), Chad, Central African Republic.

Union of Central African States (UEAC): Chad, Central African Republic, Congo (Kinshasa).

East African Community (EAC): Kenya, Uganda, Tanzania. 


\section{Samuel Chime}

\section{The Organization of African Unity and African Boundaries}

Looking at the map of Africa, if one sees boundaries as "the scars of history", it seems quite evident that Africa has had a pretty rough time during its history. For, although some will argue to the contrary, Africa is quite unique in having such a high concentration of states whose boundaries are drawn with little regard for those elements of geography-national entities or ethnic groups, convenience of economic activity or lines of communication-which often come to bear on the demarcation of peoples. In the whole of the continent there are at least twelve states which are land-locked. We find the Somalis distributed between Ethiopia, Somalia, Kenya and Djibouti, the Yorubas in Dahomey and Nigeria, the Ewes in Ghana and Togo. On the west coast of Africa we find a massive sandwich of French-speaking and English-speaking states whose economic contacts almost completely disregard the proximity of their borders. These examples can be multiplied. It is not that African states are alone in the world in having such malformations but that they have such a high prevalence of them as to suggest a system. It is this that makes it plausible to talk of "artificial" African boundaries.

In the past it has been fashionable for Africans, as if to excuse themselves, merely to point out repeatedly that it was the colonial powers who perpetrated these boundaries. However, it is close upon a decade since the Africans began actively to manage their own states. And yet these boundaries have remained. Naturally, it has since become fashionable to begin to point out that these boundaries may not be without their 
advantages. The most common point advanced in favour of this is, of course, that the boundaries have carved out nations or at least incipient nations where they did not exist before and that this was salutary. This is a highly debatable point, but I shall not be drawn into discussing it now. The fact which more relevantly concerns us now is that these boundaries have nevertheless proved to be stumbling blocks in the relations between African states. The latest fashion, in this respect, and a more profitable one, in my opinion, is to review how the African states look upon their boundaries now. After the slogans and fulminations of the period of the independence struggle, how are the African states tackling the current practical problems of boundaries, or how are they coming to terms with them?

The Organization of African Unity (OAU) is a particularly rewarding vantage point from which to look at this question. But before $I$ go any further, I wish to make some remarks about the term "boundary dispute". Doubtless there are several ways of looking at this problem. Before this seminar is over, we will have looked at it from the legal, political, economic and sociological points of view and even in terms of theory. However, as an actual African problem we may find that we cannot make too narrow a definition of the term. For instance, it has been questioned whether we ought to be drawn into discussions of minority problems and questions of self-determination when we ought to concentrate on the problems of imaginary lines between states and the difficulties in defining them. Whenever the problem of boundaries has arisen in Africa since 1969 , it has often involved just these questions of minorities and the right of self-determination. More than that, from the point of view of the $O A U$, it has affected the very goal of African unity-a unity of peoples. And the OAU has manifestly refrained from considering the highly legal aspects. I would suggest that the question of African boundaries is, above all, a question of peoples.

Article III, paragraph 3, of the Charter of the OAU pledges member states "to respect for the sovereignty and territorial integrity of each state and for its inalienable right to independent existence". This article is consonant with the gene- 
ral feeling at the $196_{3}$ Summit conference-a feeling which President Tsiranana, of Madagascar, summed up when he declared: "It is no longer possible, nor desirable, to modify the boundaries of Nations, on the pretext of racial, religious, or linguistic criteria ... should we take (these) criteria for settling our boundaries, a few states in Africa would be blotted from the map." And this, of course, the founding fathers of the OAU did not wish to see. In a sense it is paradoxical that this article was included in the Charter. After all, it has been repeated almost ad nauseam that the OAU was the culmination of the pan-African dream. And a look at pan-African history will readily show that the pan-Africans consistently regarded the African boundaries as obstacles that had to be removed at the first opportunity. The African labour and politicalparty conferences during the period between 1957 and 1963 were rabidly anticolonialist and clamoured for "the eradication of boundaries bequeathed to Africa by the colonial powers". At the 1963 Conference Nkrumah endeavoured to prevail on the delegates to render boundaries obsolete and superfluous by showing unity. How, then, was it that, at the highwater mark of pan-Africanism, the African Heads of State opted for the preservation of the colonial boundaries? Perhaps the truth is that the OAU is not the high-water mark' of panAfricanism, nor is it a culmination of it. Certainly if we examine the political relations between African states between 1957 (the year of Ghana's independence) and 1963, the acrimony between individual Heads of State, the fears-and incidence-of assassinations, accusations of harbouring subversive elements in neighbouring states, the formations of alliances, counter-alliances, and rival groups, whether they were the Entente States or the Casablanca, Monrovia and Brazzaville groups, we shall see that the OAU was, above all, a compromise between warring states (figuratively speaking, of course) with a tinge of pan-Africanism-a redefinition of a modus vivendi whose interest was best served by the maintenance of the status quo. Perhaps, then, there is no paradox after all.

Having committed its members to the status quo on the question of boundaries, the OAU set up machinery to settle 
disputes by negotiation. By Article 19 of its Charter "Member states pledge themselves to settle all disputes among themselves by peaceful means and to this end decide to establish a commission of Mediation, Conciliation and Arbitration". However, I hasten to point out that this commission is not a judicial organ nor does it have any powers of sanction. It operates, in accordance with the spirit of the Charter, only by encouraging co-operation.

Since 1963 , several border disputes have occurred between African countries. At this point I trust you will allow me to recount three examples, probably quite familiar, of such disputes, to enable us draw some conclusions as to the role of the $\mathrm{OAU}$ in these matters. The first is the Algeria-Morocco border crisis. By 1969 , full-scale hostilities had broken out between Algeria and Morocco along their common borders. The origin of the Algeria-Morocco border dispute lay, of course, in colonial history: its immediate cause, however, was a clash between the national interests of the two countries-on the one side, Moroccan irredentism and, on the other, the attractions of the mineral resources in the disputed territory. Ideological differences between the two regimes compounded the problem. It was a classic example of the danger which had haunted the drafters of the OAU Charter. A troublesome legacy from the colonial days, the border between Algeria and Morocco had never been clearly defined. There was, of course, the incompatibility between the western and traditional Islamic concepts concerning the delimitation of boundaries. Moreover successive French governments between 1830 and $195^{6}$ had failed to produce any consistent maps showing the border positions. Further complications arose when oil and other mineral resources in the Sahara were discovered, much to the advantage of Algeria. After $195^{6}$ Morocco had desisted from concluding any further arrangements with France, preferring to await Algerian independence. Indeed, in July 1961, she concluded a secret agreement with the provisional government of the Algerian Republic, in which both authorities recognized "the territorial problem created by the delimitation imposed arbitrarily by France" and undertook that this problem would be resolved through negotiations between the King- 
dom of Morocco and the government of independent Algeria.

That these developments culminated in open hostilities can be attributed partly to the political differences which arose within the two states. Ideologically Algeria and Morocco were moving apart. Algeria under Ben Bella was a revolutionary regime, in which all foreign land had been nationalized. In Morocco, on the other hand, most of the colonial land was still held by foreigners and there were many in Morocco who were attracted to the Algerian radical policies-much to the displeasure of the Moroccan Government. It has also been suggested that after the first few years of independence and national solidarity in the two states political factions grew and both leaders were willing to look for scapegoats to divert the attention of their people from their domestic problems. Certainly from $195^{8}$ the irredentist claims of Morocco grew until early in 1960, when it openly claimed Mauritania. By 1963 the situation had worsened to the extent that Morocco boycotted the OAU Summit Meeting in Addis Ababa on the grounds that Mauritania had also been invited. Meanwhile during 1963 several bilateral attempts by Morocco and Algeria to withdraw their troops from the border and to maintain a cease-fire failed. Neither President Nasser nor President Bourguiba proved to be acceptable mediators to both parties. The Moroccans, for their part, tried to put the matter before the United Nations-evidently fearing lack of sympathy from the African countries. In view of these facts, the mediation of the Emperor Haile Selassie, of Ethiopia, and President Modibo Keita, of Mali, which resulted in the Bamako Conference of October 1969 , was a considerable achievement.

The Bamako Conference declared a cease-fire, proposed the creation of a demilitarized zone and the supervision of the security and military neutrality of the demilitarized zone-by observers. It also called for an extraordinary meeting of the Council of Ministers of the OAU. At the Addis Ababa meeting of the Council in November 1963 both sides elaborated their cases. The Moroccans based their claims on historical rights, partly religious. The Algerian preferred to take refuge in the principle of the OAU Charter, hinting ominously at a so-called dynamic of territorial claims, under whose shadow 
there was imminent danger of the destruction of the stability of the continent. Apart from appointing an ad hoc commission to look more closely at the problem, the Council referred to Article 3 of the OAU Charter but not specifically to any of the paragraphs. It recalled the determination of the African States to settle their differences by negotiation and the need of doing this within a strictly African framework.

The Council met twice again between 1963 and 1964 and were instrumental in convening the meeting of the Ambassadorial Committee of the two countries, which announced a number of measures restoring normal relations between Algeria and Morocco. Later on the two countries exchanged ambassadors.

It can be said that the settlement of the Algeria-Morocco dispute was definitely a feather in the cap of the new Organization. That they were able to gain the confidence of the disputing parties was an achievement in itself. Even more so was the fact that in the heat of the hostilities the Organization seemed to be the only party which could effect a ceasefire.

Furthermore it seems that the OAU made effective use of the opportunity to consolidate its authority and its claim that African problems should be settled within an African context. It succeeded in dealing with the problem itself instead of referring it to the United Nations or a non-African power. But it is worth nothing that the OAU failed to effect a definitive settlement of the dispute. It is likely that the OAU did not feel itself able to undertake this task but preferred to act as an umpire and to mediate while the parties worked out a bilateral agreement.

Again it appears that some of the success of the OAU on this question must be ascribed to the refusal of the great powers to be involved in the dispute. If this is so, it is questionable how much actual authority the OAU can command in more critical disputes of this nature involving other big powers. We shall see later such an example.

The disputing parties also found reasons which coincided at a mutually propitious moment to put a halt to hostilities. If one of the parties had found it in its interest to continue 
fighting, would the mediation have been equally successful? Would the OAU have been able to exert effective moral pressure on that party? In view of subsequent developments on the African scene, we must also note that the dispute was between sovereign states. As such, the OAU was at least competent, within the limits of its Charter, to try to mediate. What would have happened if the dispute had fallen in the category of "internal" problems?

Finally, the OAU, in opting for the principle of uti possedetis, was opting for the status quo. This was at least true to the provision in its Charter. In the next dispute which we shall look at, we shall see a further interpretation of this principle.

The dispute between Somalia and Ethiopia and Kenya stems mainly from Somali irredentism. The Somali case was first brought to the OAU quite early in 1963. At the Summit Conference in that year the Somali delegate President Aden Abdullah Osman demanded the adjustment of the boundaries which he claimed divided the Somalis along the entire length of the existing borders with Ethiopia and Kenya. He accused the Ethiopians of taking possession of a large portion of Somali territory without the consent and against the wishes of the inhabitants. Advocating the principle of self-determination, he appealed to the UN Charter. On this occasion a verbal battle ensued between the Somali delegate and the Ethiopian Prime Minister, who made an unscheduled speech in a dramatic intervention to rebuff the charges against Ethiopia. As has been mentioned, the OAU proceeded to defend the status quo on the basis of its Charter.

The next time the problem came up to the OAU, hostilities had begun between the Somalis and the Kenyans, as well as a few skirmishes between Ethiopian and Somali troops. The OAU took up the question at the extraordinary session of the Council of Ministers in Dar es Salaam in 1964. It was with some difficulty that the matter was even placed on the agenda, since the delegates pleaded that they had no instructions from their governments on the issue. They finally agreed to discuss it by a vote of 9 to 1 , with 9 abstentions. As for Somalia, she continued to try to bring the matter before the UN, con- 
vinced that the UN rather than the OAU would be more disposed to listen to her arguments on the right of self-determination. Indeed in the debate which followed at the meeting of the extraordinary Council this was Somali's main point -the right of self-determination for the Somali population living within the Ethiopian borders and in the northern part of Kenya (the former Northern Frontier District, which incidentally the British Government had expressly refused to separate from Kenya on the accession of that country to independence).

The Ethiopian and Kenyan Governments maintained, however, that the principle of self-determination did not apply to territories within independent states and was moreover against the principle of the OAU Charter. At these discussions the Somali delegate called on the Council to arrange a ceasefire, but the Ethiopians and the Kenyans preferred that the political roots of the problem should be taken up instead. Finally the Council contented itself with merely proclaiming that "the unity of Africa requires that the solution to all disputes between member states be sought first within the Organization of African Unity". It called on the parties to the dispute to observe a cease-fire, to put an end to hostile propaganda and to commence negotiations for a peaceful settlement. This resolution also called on all African states with diplomatic or consular missions in Ethiopia and Somalia to do their best to assist in the implementation of a cease-fire. The admonitions of the Council were not heeded, although later a cease-fire was arranged between Ethiopia and Somalia through the instrumentality of the Sudanese President, Lieutenant General Ibrahim Abboud.

At the Council's second ordinary session in Lagos in February 1964 , the matter was taken up once more. Somalia requested that observers be sent to supervise the cease-fire. Although several countries, including Nigeria, Libya, Tunisia and the Congo (Brazzaville) were in favour of the idea, Ethiopia was able to block its implementation. She maintained that, rather than appoint observers, the Committee should try to prevail on Somalia to renounce her claims and to agree to respect existing borders. Both the Kenyan and Ethiopian dele- 
gates repeated their arguments against the right of self-determination.

The resolution which the Council passed on this occasion was unlike the Dar es Salaam resolution in that it referred to paragraph 3 of Article III of the Charter of the OAU on the respect due to the sovereignty and territorial integrity of member states.

Although relations between Ethiopia and Somalia and Kenya improved considerably after this, the matter came up at the Preparatory Council of Ministers meeting before the Cairo Summit Meeting in 1964. By this time Kenya and Ethiopia had signed a defence pact at which the Somali Government was protesting vigorously, arguing that it threatened the balance of power in Africa, and constituted a threat to the concept of African unity. The Council's reaction to the heated debate which this produced and the many divisions which appeared was to drop the matter from the agenda.

Further incidents took place in March 1965 on the border between Ethiopia and Somalia. Although the Somalis invited the OAU Commission to investigate the position of the Somali refuges who fled from Ethiopia and Kenya, the OAU did not take up the matter. By October 1965 , however, the Somali and Ethiopian governments had made further bilateral attempts to improve relations between themselves with somewhat limited success. As for Kenya and Somalia, a meeting arranged between them at Arusha in Tanzania, under the good offices of President Nyerere, collapsed completely since neither side was willing to compromise. Nevertheless at the Kinshasa Summit Meeting in 1967 President Kaunda met with more success in attempting to mediate between the parties. In October of the same year they signed a "memorandum of understanding" at Arusha and have since taken a decision to re-establish diplomatic relations and Somalia is being induced to join the East and Central Africa Common Market which was recently established.

Here again we note first that the OAU was unable to solve the border dispute between Ethiopia and Somalia or Somalia and Kenya. Although they attempted to effect a cease-fire between the parties, a neighbouring state was more successful in 
this respect. It is quite likely that the mediation of the OAU contributed to some lulls in the dispute but it did not do much to solve the actual problem.

Secondly, at least on two occasions the OAU shied away from discussing the problem because it was too divisive. This occurred when the Somalis protested against the military pact between Ethiopia and Kenya and also when they requested the Commission to inspect the refugee situation.

Thirdly, the OAU did not succeed in persuading a third state (Ethiopia) to allow the OAU committee to supervise the cease-fire between Ethiopia and Somalia, even though a large number of states were in favour of this.

Finally, in the latest agreement between the parties to the dispute, bilateral discussions and the good offices of a friendly Head of State proved more successful than the OAU efforts. Although a resolution was passed at the Kinshasa Summit Meeting, the actual credit for the subsequent success in the talks must go to President Kaunda.

The latest problem which is exercising the OAU is the breakdown of the Federation of Nigeria. Although it involves the right of self-determination and by the same token the redefinition of borders, it is a somewhat different kind of dispute, since, from the point of view of the OAU, it can be said to constitute an "internal" problem.

On May 30, 1967 , the former Eastern Region of Nigeria declared its independence under the name Biafra. This followed repeated and widespread breakdowns of law and order in the Federation, two military coups, the disintegration of the army and police and mass killings in northern Nigeria of civilians of eastern Nigerian origin, with about 30,0oo losing their lives and two millions escaping back to eastern Nigeria as refugees. As a result, what began on the part of the Nigerian Government as a police action against a breakaway region has become a full-scale war between Biafra and Nigeria.

At the Kinshasa Summit Meeting in 1967 a peace mission of six states was appointed by the OAU to try to mediate. For quite a considerable time the mission was unable to meet, cancelling its proposed trip several times. This was partly due to the unwillingness of the Lagos government to allow the 
OAU to intervene. The Nigerians had maintained that the matter was internal and that under its Charter the OAU had no jurisdiction. Afterwards it insisted on referring to the OAU mission as only a consultative committee. It was also reported that there was disagreement between the members of the mission. At any rate, two members-President Tubman, of Liberia, and President Mobutu, of the Congo (Kinshasa)-pleaded urgent internal duties and were unable to attend with the rest when they met in Lagos with the Nigerian commander. In a communique afterwards the mission called on the Biafrans to lay down their arms. The head of the mission, General Ankrah, of Ghana, was asked to get into contact with the Biafran leader Colonel Ojukwu. So far he has failed to do so and the Biafran leaders have found the Committee's call unacceptable on the grounds that only the Nigerian side was approached. General Ankrah has since declared that the mission has failed in its task.

Meanwhile the war continues and further mediation seems to be out of the hands of the OAU, especially as the parties prefer to deal through the Commonwealth Office-although the Biafrans have suggested that some Heads of African States should mediate, but not necessarily the OAU.

Further complications have arisen. In April the Tanzanian Government accorded recognition to Biafra, several other African states were reported to be on the verge of doing the same, and still others were said to be sympathetic to the Biafran cause. The OAU has so far proved ineffective in these matters.

The Biafran question raises a number of crucial issues for the OAU. The most important is that for the first time there is a serious attempt within the OAU to deviate from the principle of legitimacy which is entrenched in the OAU Charter. To be sure, the OAU peace mission to Lagos seemed to maintain the view that the territorial integrity of Nigeria should be respected, that the Lagos government was the legal one and, as such, deserved the support of the OAU, and they condemned secession. But the widespread sympathy for the Biafrans among African states, the willingness of certain states to accord recognition, and the Tanzanian action in going the whole hog 
cannot be taken lightly. It will be recalled that it was Tanzania which at the 1964 Summary Meeting proposed the resolution to respect the existing boundaries. Tanzania, regarded as a progressive African state and staunchly committed to the idea of unity, would have been the last country to be expected to go so far. What is more, Tanzania makes an even stranger bedfellow with the Ivory Coast (which, it is reported, is ready to recognise Biafra) in its willingness to bless the Biafran cause. President Houhpouet-Boigny has publicly praised the Tanzanian move and has hinted that he might follow suit.

The Biafrans have lost no opportunity, of course, of proclaiming their own interpretation of the OAU Charter. Judging from the precedents so far, the OAU seems to subscribe to the view that the right to self-determination, while it could be applied to colonial territories, was not applicable to sections of the populations in existing African states on the basis of language, cultural or ethnic considerations.

The Biafrans have insisted, however, that Article III of the OAU Charter applies to states wishing or attempting to invade or take over territory belonging to other states but that it does not apply to populations within existing states who are resolved to free themselves.

President Nyerere's recent defence of the Tanzanian action would suggest something approaching the Biafran position. It has been suggested that the Tanzanian decision was based mainly on humanitarian considerations. But that does not seem to be the theme of President Nyerere's defence. He asserts that "Unity can only be based on the general consent of the people ... there is no other justification for states and governments, except man".

But his views on secession have deviated from the orthodox OAU stand. Using his own country as an example, he declared: "I would certainly be one of those working hard to prevent secession, or to reduce its disintegrating effects. But I could not support a war on the people whom I have sworn to serve-especially not if the secession is preceded by a rejection of the Zanzibaris by the Tanganyikans."

Even the question of African unity does not seem enough 
to debar Tanzania from her decision: "It seemed to us that, by refusing to recognise the existence of Biafra, we were tacitly supporting a war against the people of eastern Nigeria-and a war conducted in the name of unity. We could not continue doing this any longer."

The humanitarian feeling cannot, however, be underestimated. It features more in President Houphoet-Boigny's arguments and in President Senghor's opinions on the Biafra-Nigeria war. At least three African Heads of State have insinuated the accusation of genocide against the Nigerians. The heavy toll in lives of the war, as well as the brutalities preceding it, seem to have begun to influence the opinions of certain African States on the question of self-determination. It seems reasonable to think that under certain circumstances African States are willing to overlook their determination to maintain the status quo in existing boundaries.

It would also be unrealistic not to expect that changing circumstances will affect the stand of African States on these questions. I have already referred to the creation of the $O A U$ being influenced by events between 1957 and 1963. The acrimony between African States is much less now than in those days, especially, for better or for worse, since the deposition of Dr. Nkrumah. There are not now so many accusations of subversion. Many African States can relax and take a more disinterested view of the problem.

The failure of the OAU, which is in part due to the intervention of the big powers, Britain and Russia (since they sustain the fight), has probably made the African States begin to see the problem in other terms than that of African unity.

It has, of course, been alleged that the attitude of some African States may still derive from a selfish motive. Many an African State, it is said, will not be entirely sad to see Nigeria made smaller, since its size has been a constant source of apprehension. There is no reason to place any credence on this view, especially as in the history of African affairs Nigeria has been as quiet as a lamb since 1960 .

Finally, it would seem that after the practical difficulties of the first five years of the $\mathrm{OAU}$, and the disappearance of the euphoria of 1963 , African States are now more disposed 
to look at the question of African unity more realistically. This may suggest that they are acquiring more flexibility in their principles and adapting them to changing circumstances. There is also, of course, the other side of the coin. For, who knows, it may also be a sign of a growing disenchantment with, or even disbelief in, the very idea of unity. 


\section{William Zartman}

\section{The Foreign and Military Politics of African Boundary Problems}

Any African state can have boundary problems if it wants. The newness of African states and the frequent irrelevance of their geographic frames to their economic, social, and political lives make the continent potentially more susceptible to territorial disputes than any other. There are so many real and possible boundary problems in Africa that it is a living museum for taxonomy and analysis.

Boundary problems are policy problems. A government decides whether it wants to claim neighboring territory, and then decides how to pursue its goals. The problem may also be thrust upon the state by its population, by an accident or by some other secondary source, but the government makes the decision on whether to pursue the matter or not. Sincein the age of self-determination-no such claim can be credible and legitimate without popular support in the contested area, it is always useful to be able to cite a spontaneous invitation and it is usually possible to obtain one. In rare cases, this invitation may be truly spontaneous: Africa gives no unambiguous examples. Up till now, there has always been a political figure on the claimant's side of the border to articulate wishes before they became popular. Or the spontaneous incident has been a raid or refugee movement across the border, with little relation to territorial claims. If the claimant state can turn on its popular incident, it can also take measures to turn it off. Which of the two is more difficult clearly depends on the individual situation: it may be hard to find a credible spokesman for annexation among a satisfied population, and it may be equally difficult to calm a clamor that 
has caught on. Boundary problems arise from the efforts of states to achieve coincidence among its three units of interest and identity-the popular unit or nation, the organizational unit or party-government, and the territorial unit or country. Here we are focussing on the dynamics of frontier conflict, by analysing efforts of governments to alter the limits of the nation and/or country. My purpose is to attempt answers to several questions about the policy process. Why do states in Africa make border claims? How are border claims in Africa pursued? How are they settled?

\section{Justification of boundary claims}

States make boundary claims because they believe that either the people (popular unit) or the land (territorial unit) in question are or were theirs." Historic claims over a larger population reflect an earlier notion of sovereignty, where the boundaries of the state were determined by the extent of its people, not of its territory. As a basis for a territorial claim the notion is rare, since it depends on an historic state continuing from pre-colonial through colonial to present times. It is also vulnerable, since there are current means for determining popular wishes that make such historic claims irrelevant; the claimant must therefore justify not only its claim, but also the historic basis of the claim and its refusal to put it to a modern test.

Morocco has done this through the use of Islam, for if religious duty makes allegiance to the King obligatory, then there is no need for a referendum-indeed a referendum itself is sinful, in that it provides a temptation to error. ${ }^{2}$ Morocco's claim over Mauritania, the largest irredenta in the continent, is based on the allegiance paid by the Muslim community of northwest Africa to the Sultan and Imam of Morocco in precolonial times, and on the continuity of the Sherifian Empire through French and Spanish colonial rule to modern Morocco. The Istiqlal leader, 'Allal al-Fassi, preached MoroccanMauritanian unity after World War II, a decade before Moroccan independence, and King Mohammed $\mathrm{V}$ adopted the 
policy in $195^{8}$. As recently as late 1967 , an Istiqlali news paper wrote:

Moroccan territorial claims derive their legitimacy from basic international law and from the effective exercise of Moroccan sovereignty over these territories until just before independence. Furthermore, undeniable ethnic and historic facts demonstrate the Moroccan character of these areas, and finally, the people in some of these areas have shown their desire for ties with their mother land, Morocco. ${ }^{3}$

But Mauritania held a referendum in 1958, at the height of the Moroccan campaign, and attained independence two years later, followed by UN membership the following year and founding membership in the OAU (whose first meeting was boycotted by Morocco) in 1963 . Morocco's claim has not been substantial enough to win it either support or success. Yet the religious message of the Istiqlal was at least strong enough to turn Mauritania to seek better relations with other North African countries, showing that Mauritanians could be good Arabs and Muslims without being Moroccans. Although never officially renounced, Morocco's irredentist campaign has suffered decisive defeats.

Current claims over a larger population have a more diverse basis. The simplest is national overhang, in which a recognizable nation extends beyond the boundaries of its state. In view of the current widespread acceptance of the desirability of national unity and of the "artificiality" of African boundaries, an apparently strong case could be made for border rectifications to encompass one nation within a single state's boundaries. Yet the available African example is both as unique and as unsuccessful as the preceding case. Like Morocco, Somalia was born truncated.4 But whereas Morocco was a truncated state containing several ethnically distinguishable populations and little to set it off from its neighbors, Somalia is a truncated nation with a single national language, a common ancestry and history, and a clear cultural and even visible physical differentiation from its neighbors-the only such case in all Africa. Irredentism was adopted with independence as state policy and was maintained for over seven years. The 
immediate result was a ring of hostile neighbors besieging Somalia on the Horn of Africa; Somalia was denounced at the founding meeting of the OAU, and isolated during the subsequent war with Ethiopia and raids into Kenya. It was only after the Khartoum revolution of 1964 had unleashed new forces in the Sudan that Somalia began to find a useful ally in its neighbor's neighbor, but Somalia still did not have enough power to move its borders. Militarily contained, diplomatically isolated, yet championing an attractive-if hopeless -case, Somalia suddenly changed course in 1967 when the new government of Mohammed Egal came to office. Seeking to "strip the problem of its importance", Egal has met with each of Somalia's neighboring governments to improve relations, and then with all of them to join in regional economic co-operation.

It is a major step from the truncated nation-state to national overhang by minority groups in multi-nation states. It is doubtless the commonest situation in Africa to find ethnic groups who wish to be united with their fellow men across the border and whose desires are used by the government to justify boundary changes. Since any African state could make dozens of such claims along its entire frontiers, additional elements might be suspected in the boundary disputes that did break out. Mauritania has put in an advance claim over Spanish Sahara for the moment when the Spanish withdraw, since "there is no difference between the people of Spanish Sahara and those of Mauritania" (although this is not true of all the people of Mauritania). Ghana laid claim to Togo because "Ghana and Togo are one" (although neither all Ghanaians nor all Togolese are Ewes). Djibouti is one of the unredeemed points of the Somali five-pointed star (although the Afars are not Somalis-only the 'Issas are). If these examples give any indication, minority overhang is invoked when the neighboring minority is oppressed or when the neighboring colonial regime is on the point of collapse. Yet these "additional elements" are circular, to say the least, and do not give much insight into the use of minority overhang. As the Kenyan government asked: "How does the Mogadiscio government expect the Kenyan government to hand over part of its territory? The 
Somalis are not the only ones to be divided in East Africa. The Masai are divided between Kenya and Tanzania. The Galla and Boran tribes live in both Kenya and Ethiopia. There are whites, Indians and other races who have families both in Kenya and in their home countries, but none of these people claimed the lands on which they settled ... what is it that festers the Somalis?" 5

There are other ways, however, by which current claims over a larger population can be generated, even if national overhang is not an established fact of the recent past. Population movements and changes of allegiance can provide the bases for new claims without historic precedence. Völkerwanderungen have occurred in Africa and are reflected notably in the Somali claims, particularly on Kenya. The southward Somali movement has been a slow process of centuries, and it was not until the early $\mathbf{1 8}_{\mathbf{8}}$ os that Somalis crossed the Juba river into Trans-Juba and then into the Northern Frontier District of Kenya. Smaller movements, particularly among traditionally pastoral and/or raiding populations, also tend to produce border problems, often reflected in boundary claims. Mali and Somali both put forth demands for border rectifications to permit access to neighboring wells. This too is a problem that is endemic to African boundaries, where state lines invariably cut across traditional lanes of social and economic-and hence often political-activity. Endemic to the broad belt of countries from Mauritania to Somalia is the "shifta" problem (known by other names in western Africa); while sealing the frontiers across which the "shifta" raid may be one answer to the problem, another may be the exchange of territory, so that their area of operation falls within a single jurisdiction.

Finally, population movements can be generated contemporarily by a marked improvement of conditions on one side of the frontier over those on the other, which could be called the "greener grass" or Speckdänen phenomenon. Scattered examples have occurred in Africa. The transfuges who supported Morocco's claim to Mauritania fled from Nouakchott to Rabat between $195^{6}$ and $195^{8}$ because political fortunes were bad in Mauritania and life was better in Morocco; a number 
returned in 1963 when the changing Mauritanian scene had stabilized. The tremendous refugee problem is Africa's instinctive answer to the artificiality of frontiers; ${ }^{6}$ war, repression, or famine create mass movements, first to other areas inhabited by the same ethnic groups and then beyond, with little regard for meaningless boundaries. Refugee movements have not been used extensively as justification for territorial claims, even though minority overhang is usually involved. In general, short-term population movements create border problems, and only long-term movements coupled with stronger appeals have been used to support boundary claims.

Like population claims, territorial claims can also be based on historic or current factors. Historic claims based on the principles of colonial uti possedetis have a strong case, since the successor-state notion is the primary juridical justification for any boundaries in Africa today. Thus, if the independent state can show that the colonial boundaries were more extensive than current ones, a prima facie case can be made for rectification, although usually only in regard to minor delimitation. Minor use of the principle was made in various border surveys, such as that between Nigeria and Dahomey. More extensive territory was involved, on the same basis, between Ghana and Upper Volta (re-affirmed in June 1966 on the basis of the Franco-British Treaty of 1890 ), between Sudan and Ethiopia (re-affirmed in June 1966 one the basis of an AngloEthiopian protocol of ${ }^{1903}$, but recalled into question in 1967 ), and between Mali and southern Mauritania (corrected in February 1963 , modifying internal French decrees). Large parcels of territory have been involved in a rare problem of African succession, the former German colonies. Both in southern (British) Cameroons and in Togoland, the idea of re-unifying the former German territory was a major argument among unificationists, and was effective in the formation of the Federal Republic of Cameroun; it was not a successful argument in Togo, nor in the northern (British) Cameroons, both of which areas rejected reconstitution of the former German frontiers in referenda. ${ }^{7}$

Pre-colonial uti possedetis has been invoked on occasion outside of government circles, in press and parliament, by spokes- 
men who allude to reconstituting the frontiers of an historic kingdom. The Moroccan argument, although more complicated, as we have seen, also uses similar language. If the subnational overhang would open Pandora's box, however, pre-colonial uti possedetis would open a nest of boxes. Morocco's claim implicitly recognizes this by positing the unique continuity of the Sherifian Empire through the colonial protectorate, and African statesmen have almost unanimously agreed that the movement of independence is the oldest admissible reference point for boundary justification. Liberia's border claims have taken this fact into account as well: until its neighbors became independent, Liberia continued to press border claims against the colonial regimes which had gradually eaten into Liberian territory, but once Guinea and Ivory Coast achieved sovereignty, Liberia recognized the territorial status quo.

Current territorial claims have several referents. It is frequently suggested that expanding states seek new territory because it has some natural resource that they find attractive, but boundary claims, as we have seen, cannot be justified simply by wants: a state must be able to claim that a particular land "is" national territory and that the boundary should be adjusted to reflect this fact. The question is then one of establishing a right to the richly endowed territory. When the natural resources are grazing lands and wells, this right is apparently not too difficult bo assert; the justification is of a previous order, however, because it is the population movement to the grass and water that validates the claim. Justification by natural resources-and not simply for them-is rare. Tunisia from time to time has been able to raise its indefinite claim to a southern projection of its present territory by claiming that "the Sahara belongs to all littoral states", since it is a "sea" in which no boundaries make any sense. Since the argument can be returned without rewording, to suggest that the claim makes no sense either, there are few other such cases in Africa.

A corollary referent of current territorial claims is the natural frontier, stated in geographic terms. Despite the rarity of natural geographic lines in Africa, the "Rheinflüsse nicht 
Rheingrenze" argument could frequently be used. It has not. States which border on rivers have not put forward the "natural basin" argument, and states which are near rivers (or mountain ranges, when they exist, or coastlines) do not claim their "natural frontiers". 8 The only manifest destiny of African states appears to be to save smaller states from an uneconomic fate, and then only hesitantly. Thus, a Cameroun newspaper hopes that Rio Muni will "freely determine to join the Federal Republic of Cameroun in a more viable ensemble". $\theta$ Senegal patiently waits for the Gambian anachronism to pass away, and the Congo does not consider colonial rule in Cabinda illegitimate enough to treat it as the Dahomans treated Ouidah.

Finally, the most frequent current territorial justification is simply that the border is unclear or nonexistent. Colonial benchmarks were often trails, trees, huts, intermittent streams, and other striking but nonpermanent features of the landscape; even when more durable, features were often designated by ambiguous local names, translated by foreign interpreters, and inaccurately recorded. In the process of delimiting and demarcating, new problems may arise. Even if Somalia did not have its irredenta, it would still have a boundary of disputed lines and contested points separating it from Ethiopia. Even if Morocco did not have its irredenta, it would still have to draw a line where there now is none to separate it from Algeria.

\section{"Real" causes of boundary claims}

Historic and contemporary claims on neighboring territories or populations are proximate causes for boundary problems, and they vary in credibility and legitimacy. But behind these causes lie others. Their presence and nature can usually only be inferred, since they are not the public justifications but the private motivations, and hence nearly impossible to prove. Usually their credibility and legitimacy is less than that of the public justifications, although they do come to the surface on occasion, when they can stand on their own as justification or when they are addressed to an internal audience. To sug- 
gest that there are underlying causes in general does not mean that in any particular case the proximate causes are not the real ones. Such determination will vary with the case, and may never be able to be made conclusively. The purpose here will be to enumerate some major types of underlying causes and give acceptable examples-as above-rather than to diagnose the underlying or real cause in every African border dispute.

One group of reasons concerns the value of the territory itself. The lure of natural resources has already been suggested. While it is unlikely that mineral deposits are the real or only reason for Morocco's southern claims, it is certainly true that the possibility of common exploitation of the Sahara, including the iron deposits at Gara Jebilet, provided the first occasion for official Moroccan claims over nearby Tindouf, and the discovery of phosphate deposits in southern Spanish Sahara (Rio de Oro) worked against any Moroccan agreement to share the territory with Mauritania, the northern part alone (Saqiet al-Hamra) going to Morocco. More broadly, size alone may be a basic reason. A Moroccan ambassador once remarked privately that this country needed more territory to "look as big as Algeria". Such considerations may also have been a factor in claims over Togo by Ghana, which had aspirations to continental leadership under Nkrumah that were far bigger than the size of the country.

Sometimes border claims are purely accessory, either to domestic or foreign politics. A border dispute can provide a useful scapegoat or safety valve for a troubled political system. Although such a function was probably not the cause of Somali irredentism, it became so useful to have the dispute around that there was no obvious need to do away with it. When domestic politics deadlocked in the bickering of component clans of the Somali nation or domestic economics deadended in the poverty of resources in the Horn of Africa, national unity could be quickly restored about the border issue. Thus, in 1964, parliament passed no bills for twelve months, but it did pass a resolution affirming irredentism as Somali policy. Other African states had little sympathy for the Somali cause, but it won attention from China and competitive bidding for defense aid among the U.S., the U.K., Germany and 
the U.S.S.R., ending in sizable military assistance from the last. It took seven years and an exceptional Somali statesman to see that this approach to politics was leading nowhere, although, regretfully, either he or his successors may find reason to regret the loss of the safety valve. In West Africa, too, Olympio was probably as guilty as Nkrumah of using the boundary dispute for his own domestic political purposes, particularly at election time.

In foreign policy, boundary problems may be raised accessorily to other outstanding issues to improve one side's bargaining position. Tunisia's apparently contradictory position finds an explanation in this light, as Tunis indicated that it would prefer a dépassement of boundary disputes through cooperation among littoral states, but if such co-operation was impossible, a new division of the Saharan territory was in order. It is hard to tell if such a tactic has been successful, since it is impossible to judge what might have happened had it not been used; in any case, there has been no formal, far-reaching, multilateral co-operation over the use of Saharan resources.

Border problems, and eventually boundary disputes, can also arise out of bad relations between ideological enemies (just as they can also turn ideologically similar states into enemies). The parenthetical case is rare, however, unless one counts Nkrumah's and Olympio's personal regimes to be ideologically similar. For whatever conclusions can be drawn, it is worth noting that border disputes and boundary problems have not arisen between Guinea and Mali, Ivory Coast and Upper Volta, Upper Volta and Niger, Chad and the Central African Republic or Mali and Algeria or among the three states of East Africa, all states whose regimes have vaguely similar political outlooks. Although there are too many variables to provide any conclusive correlation, it is certain that boundary problems tend to be articulated in ideological terms if the least occasion is present. There is scarcely an exception in Africa: the Sanwi problem, the Lete problem, the Ewe problem, the Wadi Halfa problem, the Djibouti problem, as well as the perennial Moroccan and Somali irredenta have all been shouted out through the use of ideological opprobria. Even 
simple-if annoying-"shifta" problems between Chad or Ethiopia and the Sudan turned into bitter name-calling contest before they were calmed by responsible government action. In fact, the initial threshold for determining whether a government will pick up the border problem and make it its own or hold it down and move to settle it is usually at the point when it decides whether to enter into a propaganda war to test the opponent's will and intentions.

The list of underlying causes could be extended indefinitely as one probes into the psychological motivation of political leaders. It is unnecessary to do so to make the point that boundary problems generally do not arrive alone, but make up part of a complex of issues arising between two neighboring states. Whether the atmosphere must be already poisoned for a boundary dispute to flourish or whether the boundary problem itself is sufficient to poison its own atmosphere and create bad relations is as impossible to disentangle as the earlier question: Which comes first, the official claim or the spontaneous popular unrest? In both cases a policy decision is necessary either to pursue the claim or arrest the cause. When neither decision is taken, there is likely to be continued border trouble but no boundary dispute. One decision or the other will determine whether the problem will spiral upward to a full-fledged campaign or downward to settlement on the basis of the territorial status quo.

\section{Escalation of boundary conflicts}

It has already been suggested that the crucial decision is often the one on whether or not to engage in a propaganda war. This is logical, for the major problem in pursuing boundary claims-as we have seen-is the establishment of credibility and legitimacy. That it is also realistic is attested by the fact that the first move of de-escalation in both irredentist campaigns was a propaganda truce between parties, concluded at Khartoum in 1964 between Somalia and Ethiopia, at the Cairo OAU Summit Meeting the same year between Morocco and Mauritania, and at Nairobi and Arusha in 1966 and 1967 
between Somalia and Kenya. Needless to say, there is no unique irreversible sequence of moves for boundary problems to follow in escalating or in de-escalating, nor is the propaganda decision a universal threshold. Indeed, the fact that some states are born with boundary problems and some have boundary problems thrust upon them indicates that no two patterns of events can be expected to be the same. Furthermore, much depends on the response of the neighbor. With all these qualifications in mind, however, it seems possible to list a number of measures that can be taken by states when they pursue a boundary claim, and a number of others to be followed in seeking a settlement on the basis of the status quo.

The path of direct conquest has been only rarely and ambiguously tried in Africa and never successfully. Conventional warfare has been user only in connection with the two irredentist cases, both apparently begun-in the conventional warfare phase-by the non-irredentist state after a long period of border incidents. The Moroccan-Algerian war of October 1963 arose from an escalation of incidents, not as an attempt to conquer and hold territory, although the original incidentsif they had a purpose-may have been designed to take over territory of ambiguous ownership "when no one was looking". Similarly, the Somali-Ethiopian war of late 1963 was a punitive reaction to informal incursions into Ethiopian territory; the incursions were part of an irregular, local, liberation war, but the conventional war that followed was not designed to change the frontier. A third brief military confrontation did occur in February 1958, when Egypt briefly occupied Sudanese territory and then, threatened with a UN debate, withdrew.

Regular armed forces have been used to repulse irregular infiltrations along the borders, although this too is an exercise in defense, not in promoting claims. Police, gendarmery, border guards, and army have been used by Mauritania against Moroccan territorists, by Chad, the Congo, the Central African Republic, the Sudan, Ethiopia, Kenya, and Uganda against insurgents and "shifta", and by Guinea, Ivory Coast, Ghana, and Togo in various attempts to control or encourage border harassment against neighboring regimes, with territorial claims variously intermingled. Such needs are expensive: Chad 
in $1967-68$ devoted a quarter of its budget to controlling insecurity on the Sudanese border.

On the other side of the coin, para-military activities are used to further border claims. The use of guerrilla forces and terrorist agents is more closely associated with boundary disputes in Africa, because these activities have the appearance of a popular manifestation and hence strengthen the claim of spontaneity and popular self-determination; in contrast, formal military invasion from the other side of the border looks like conquest pure and simple (a conquest associated in popular imagery with colonialism, and for which African armies are simply not equipped). Thus, Moroccan support and encouragement of guerilla warfare, marauding tribes, and terrorism in Mauritania was designed to show that the Mauritanian government did not represent its people. The irregular warfare of the Somali guerillas was truly locally-inspired, although probably armed from Mogadiscio, and the efforts of similar Somali activities in northeast Kenya were aimed at contesting the Kenyan claims of having satisfied populations within is borders. The Sudan housed and abetted the "Government of the Islamic Republic of Chad in exile" in 1965 , reportedly in return for Chad's northern territories.10 Beyond these cases, terrorism and subversion were frequently matters of intervention, 11 not merely of boundary claims.

Other than through military and para-military means, boundary claims are pursued primarily by propaganda and diplomacy. Propaganda is important for the same reason as paramilitary activity, and in fact the latter has reinforced the former as "armed propaganda" in Africa as well as in Latin America; propaganda amplifies expressions of local sympathy to generate greater local sympathy, and thus to strengthen justification of the cause. Propaganda can also place the boundary dispute in a broader, ideological context: if the other government can be shown to be reactionary or subversive (depending on the propagandist's values), it does not deserve to govern the country in question, let alone the disputed territory, whatever the views of the territory's population. It is hard to make any evaluation of the effectiveness of such propaganda in furthering the cause of boundary claimants: one 
often suspects that it is self-reassuring propaganda, particularly since it tends to be couched in terms appealing to the emitter, not necessarily to the receiver. But regardless of the audiences intended and effectively reached, propaganda is a constant companion of boundary disputes. Even such picayune matters as the Niger-Dahomeyan dispute over the seasonal Lete island, or such routine matters as the Chad-Sudanese dispute over border marauders degenerated into a bitter propaganda battle, apparently for primarily home consumption.

Diplomacy also requires support from propaganda, both in the ideological terms that satisfy home audiences and in the justificatory terms that strengthen the cause. The diplomacy of boundary problems is a vital part of African international relations, and it fits in with the mobile alliance pattern within the framework of broad ensembles that is such a prominent characteristic of post-1963 relations among African states. ${ }^{12}$ If military effort is unusual-indeed, even excluded by interAfrican norms-and propaganda is the threshold indicator of a state's policy in pursuing boundary dispute, the search for allies is the most readily available means of increasing power.

Examples of the diplomacy of boundaries are legion. Before 1963 , boundary diplomacy led to the competing alliances that were the salient characteristic of pre-OAU African international relations. Moroccan irredentism pushed Mohammed $\mathrm{V}$ to seek allies by calling the Casablanca Conference of 1961 ; other states joined in partly because of a need for allies in their particular boundary problems (Ghana with its neighbors, the United Arab Republic outside the continent with Israel). Niger in the Lete dispute found support from its fellow members in the Council of the Entente, from which Dahomey was momentarily excluded. Mauritania's defense against Moroccan claims was one of the major reasons for the formation of the Union of African States and Madagascar (UAM). After 1963 , alliances loosened, and ad hoc support and friendly relations with opponents' allies became the best that diplomacy could obtain. Mauritania could leave the Common African and Malagasy Organization (OCAM) in 1965 both because its purpose in assuring its independence had been accomplished and because its foreign policy entered a new phase, where its 
campaign against Morocco required mending fences with Algeria and the UAR, Morocco's former allies, thus undercutting Morocco's support in the League of Arab States (LAS).13 Ethiopia and Kenya allied against Somalia in 1969 , even before Kenya achieved independence. Somalia finally broke out of its isolation in 1965 with improved relations with the Sudan, which was also having border problems with the common neighbor, Ethiopia; at the same time, the Sudan became active in supporting the Eritrean Liberation Movement, a Muslim group opposing Ethiopian rule. In 1966 a Somali delegation visited eight Arab countries and spoke of joining the LAS, in order to win allies, after which the Emperor of Ethiopia also made a Middle East tour. Togo, which had periodically discussed closer relations within bilateral and regional (Benin) co-operation with Dahomey and Nigeria as Nkrumah's campaign rose and fell in intensity, eventually joined the Entente in 1966 . In turn, the boundary incident is synchronized with diplomacy: during the Emperor's Middle East tour the Somalis paraded "Arab victims of Ethiopian colonialism", and just before the Moroccan-Algerian border commission meets, border clashes are likely to occur, or at least to be protested.

As major boundary claims and irredentist causes have fallen off, the search for allies has become less desperate, leading to greater mobility and less intensity in African political groupings. Alliances then tend to become-at the same time-more positive (or inward-directed), less urgent, and more overlapping, as the vital need for security and defense against pressing danger recedes. At the same time, diplomacy has been weakened as a tool, by the fact that African States are frequently reluctant to take sides in African disputes (and especially boundary disputes). The three irredentist states could find no firm African allies for their cause. Two African states may not hesitate to enter into conflict with each other (and two having a common fight with a third may pursue their cause jointly). But a third party, even if friendly or allied with one of the contestants, is unlikely to support the latter against its enemy. Thus, when disputes arise, diplomacy is useful to secure the neutrality of the enemy's friend or ally. 


\section{De-escalation of boundary conflicts}

Once boundary disputes have escalated to the point of deadlock, defeat for the claimant, and counterproductive expense for both sides, they tend to lose momentum and gradually de-escalate. Although the mechanism is evident in the histories of boundary disputes, there is no a priori way of telling when the crest occurs. Often efforts at settlement by third parties are patiently pressed and re-pressed until deadlock, defeat, and expense have sunk into the consciousness of both parties. It is clear from the escalation-and-de-escalation pattern, however, that third parties are an important part of the settlement process, since, after a period of escalation and then deadlock, a face-saving means is needed to begin the detente. By the same token, détente and de-escalation do not necessarily mean rapid settlement or real settlement at all: the dispute may simply be stripped of the means of its being waged, without the basic problem being resolved. This sort of deadlock at a lower level is possible in Africa as long as boundaries remain vague and as long as the disputed areas are not regions of intense human activity that would bring the dispute back to life. In sum, boundary disputes in Africa tend to de-escalate because the means of pursuit are unavailable and the dispute proves more expensive than the possible prize, much more frequently than because the actual territorial question is resolved. A truce is more likely than a treaty. ${ }^{14}$

One means of de-escalation, then, is mediation. In line with the general norm-embodied in state policy statements and in OAU resolutions-that African problems should be settled by Africans as well as by peaceful means, Africans are ready mediators. Haile Selassie and Modibo Keita brought about a truce between fighting Moroccans and Algerians, and Habib Bourguiba brought the parties a step closer thereafter. Ibrahim Abboud, Julius Nyerere, and Kenneth Kaunda all gradually moved Somalia toward a truce with Kenya and Ethiopia. Hamani Diori and Jean-Bedel Bokassa actively mediated the border dispute between the Sudan and Chad. Not enough is known of the actual negotiations to permit analysis of the appeals used by the mediator, but one common characteristic 
of the crises is that both parties were worn out-in one or several senses-by the dispute and ready for mediation. There are, of course, cases of unsuccessful mediation-Senegal between Mauritania and Morocco, Tanzania between Somalia and Ethiopia, Ivory Coast between Dahomey and Niger-when the dispute had not yet "run its course" and the parties were not yet exhausted.

A correlated means of de-escalation is the use of an international organization. In general, such bodies have worked more effectively as a "place" than as a "thing" in de-escalating boundary disputes, that is, they have served as a natural and neutral meeting ground for the disputants and a forum where fellow African states can exert pressure for reconciliation, but they do not serve in any corporate capacity as a mediator themselves. Thus, the OAU had no direct role in ending the two irredentist wars; it only provided pressure for meeting with mediators or for investigating the problem afterward.15 Similarly, the UAM, the UAMCE and the OCAM have helped to solve disputes by bringing together disputants, not by intervening directly.

There are also occasions of direct bilateral negotiation and settlement, cases which are rare but which are notable for having provided resolution of the issue and not merely truces in the dispute. The unique case of direct negotiations, mutual concessions and a new boundary is provided by the Mali-Mauritanian settlement of 1963 . Liberia also gave up territory it did not possess, along with claims to it, in bilateral meetings with representatives of Guinea and Ivory Coast, as Ghana did-finally, after long and inconclusive OAU pressure-in favor of Upper Volta. There are a number of other cases in which states have met bilaterally to settle border problems not involving territorial claims. The Sudan has made agreements with at least three neighbors, either to refuse entry to dissatisfied minorities or to settle them away from the borders. There are also a few cases of agreements between states to demarcate an uncertain boundary before thorny problems and touchy relations could arise. ${ }^{16}$ When negotiations do reach the point of final settlement, technical geographic surveys are the ultimate recourse, often coupled with a bilateral commission to 
review problems periodically. ${ }^{17}$ Curiously, perhaps, the referendum has only been used twice, in British Cameroons and Togoland, and then only before independence. Various national votes have had the effect of territorial referenda in Mauritania and Algeria, but nowhere else in the continent have popular consultations been employed. Morocco rejected its proposal of a referendum in its irredenta, on the grounds that one does not hold referenda in one's "own" provinces. There are many reasons for questioning a final, unappealable but unappealing verdict: nomadic populations, unclear national identity, too clear national identity. To be sure, there is much that is sound in these reasons, but they do again point to the somewhat ironic conclusion that, in the continent of national self-determination par excellence, state policy and state determination are the active agents in boundary problems.

\section{Future prospects}

This review has attempted to discern and evaluate the means of raising, pursuing and settling boundary problems in Africa, drawing some conclusions along the way concerning the nature of these means. As a final conclusion, based on these lessons, it is worthwhile assaying the future possibilities of boundary problems. An extension of the above points strongly suggests that old irredenta will continue to decline in the future and new ones will fail to develop. The starting-point for projecting the future failure of African irredentist movements is their past and present failure. In the two major irredentist movements of eastern and western Africa, a crest has clearly been reached and de-escalation has begun. This fact alone is by no means sufficient to predict continued decline in the problem (a simple enumeration of the Moroccan-Algerian conciliation meetings under the auspices of the OAU since 1963 suffices to make this clear). But it is sufficient to indicate that a new series of incidents, new policy decisions, and a reversal of the present level and trend of events are necessary for the problem to come alive again. The propaganda threshold has clearly not been left behind in Moroccan-Algerian relations, and blasts are aimed from one capital to the other at 
short notice. But this level of dispute serves both as a warning and a substitute for real action: it allows failure without admitting it, not an unacceptable state of affairs from any point of view. In the Somali case, the Prime Minister has made deescalation a principal plank of his policy. A vaguer case of irredentism, in Ghana, has also lost its fire with the deposition of Nkrumah, and here the chapter has been brought to an end.

Even though the parties, the means, and the stakes are all being exhausted by these disputes, the two major irredenta still do have significant potential for revival. Spanish Sahara, actually separating Morocco from Mauritania, and Afar and Issa Territory (formerly Djibouti or French Somaliland), between Ethiopia and Somali, will remain bones of contention as long as the question of their final disposition is open. Colonial rule forms an acceptable alternative to conflict for the present, as long as one side does not see the other gaining decisive advantage: these territories are thus buffer states, with all the instability that this status implies. The former is gradually moving toward independence, while Spain conducts skillful, secret, parallel negotiations with both Morocco and Mauritania, who have both posed their claims. Final determination is to be by referendum, although the sharp UN debate in 1966 on the conditions of the vote suggest that results may be contested. The referendum of 1967 in Djibouti reaffirmed French intention to remain, so that disposition of this territory is postponed. The fact that the Addis Ababa port and railhead is located on this Somali-inhabited territory promises to revive the dispute at a later date, no matter how firm the reconciliation.

These two exceptional opportunities for dispute in the future must be seen in the light of other factors, however, such as the availability of means to pursue boundary problems. One is military. We have seen that the general pattern is one of border incidents leading to military action, leading to exhaustion, leading to mediation. Is there anything that allows the suggestion that this pattern will change? In general, African armies are becoming better organized and better equipped; it is impossible to claim-particularly in the light of the long and 
inconclusive Biafran war-that there is any decisive improvement in the military capability of the armies themselves, particularly in using the weapons at hand. Furthermore, there is no area where one army has so significantly improved its military capability in relation to its neighbors, and the economic machinery to back a decisive military venture has not significantly improved in any African state. War has been catastrophic to the Nigerian (and Biafran) economies, as it was exhaustive to Morocco and Algeria, even though they were much more developed than African states south of the Sahara. There is therefore no prospect of a blitz such as the Israelis carried out. Of all the contested territories, only Tindouf offers an area where a sudden seizure might be possible, and the exposed nature of Figuig provides a region where Algeria could effect a counter-seizure that would result in the same sort of stalemate already noted. Thus, any rational calculation of military prospects would deter an attack of conquest, and, if an irrational miscalculation were made, the results would still be likely to be stalemate and exhaustion.

The diplomatic means are also limited. Boundary disputes no longer appear to be attractive reasons for firm political alliances. In the early years of independence, legitimacy and security were so fragile and isolation so much feared that an alliance race was endemic. The OAU, and the failure of territorial challenges, have helped to assuage this need. An inchoate Kautilyan pattern of relations began to appear in eastern Africa after $196_{5}$, but it never attained the degree of commitment or intensity of the interlocking alliances of West Africa in the $195^{8-63}$ period or of the dual ideological blocs preceding the formation of the $\mathrm{OAU}$ in the latter half of those five years. Neither the second Congo nor the Chad-Sudan crises broke the mobile concert system under the OAU. This is not to contradict the point that allies are still the major means of increasing power in Africa; I merely state that the intensity and commitment of alliance required for a concerted territorial campaign is unlikely to appear. Again, a rational decision to pursue boundary claims with the support of allies is unlikely, and an irrational miscalculation is likely to reveal that allies quickly develop cold feet. 
By extension, the OAU is also most unlikely to give support to boundary claims, both because it has already and repeatedly gone on record against them and also because it is generally unable to take a strong stand against the status quo concerning one of its members, such as would be required to support a border claim. The OAU provides a forum where norms are proclaimed, a weak alliance for coordinating liberation policies, a locus where conditions and pressure for reconciliation can be provided, and a source for finding mediators (either in the persons of individual members, ad hoc committees, or the newly established Mediation, Arbitration and Conciliation Committee). None of these functions lends itself to supporting boundary claims, and all of these functions appear to be about the maximum that the Organization can provide in the near future. The shift in norms from the revisionist stand on boundaries proclaimed by the All-African Peoples Organization in 1958 to the status quo position decreed by the OAU, notably in 1963 and 1964 , indicates that Africaindividually and collectively-is getting used to its condition.

Finally, boundary problems are unlikely to incite outside support. The general trend in Africa appears to be leading toward the diminution and probably withdrawal of the European police function of keeping order among Africans. In view of Africa's limited means for carrying out disputes, this is a stabilizing factor. Reference to foreign support in recent years has diminished. Great Britain discussed with the Nigerian government the advisability of intervening in the Biafran war and both parties decided against it. Houphouet-Boigny publicly told Sekou Toure's allegedly poised armies that Ivory Coast had allies, both in Africa and outside, but the proposition was never put to a test. A French parachute company's arrival in the Central African Republic raised unconfirmed suggestions that border problems with the Congo were somehow involved. France did intervene in 1968 to help calm the restive Chadian north, but after the problem had ceased to be international. Perhaps most significantly, Morocco and Algeria, two important states with a number of close extra-African ties, were unable to raise a significant commitment from outside the continent during their border war. Again, a rational deci- 
sion would recognize this, and a mistake would feel its effects.

Throughout this review, an implicit distinction has been made between border difficulties and boundary problems. The former refers to the inevitable hazards of trying to draw and enforce a line that divides neighbors; the latter refers to claims made on neighboring territory. Border disputes will certainly continue to arise, invalidating agreements, embittering relations, arousing populations, and requiring new rounds of reconciliation and agreement. Problems of refugees, subversives, pursuing border guards and unclear boundaries will gain importance with the context of broader political or ideological differences, starting an escalation process that will spiral upward until the parties realize that the real cost exceeds the potential gain. Then they will de-escalate again. But both a history of past problems and an evaluation of future means indicates that boundary problems involving large areas and large-scale attempts to recover them are likely to decline among African states. 


\section{The Sources of Status Quo and Irredentist Policies}

The record of inter-state relations in Africa shows that there were only four states which embarked upon irredentist policies: the Somali Republic, Morocco, Ghana and Togo. Their irredentisms, challenging the legitimacy of existing boundaries and of the corresponding territorial apportionments, have caused five major conflicts: between Somalia and Ethiopia, between Somalia and Kenya, between Morocco and Algeria, between Morocco and Mauritania, and between Ghana and Togo. 1

All other African states, with the exception of the four listed above, accepted in principle the existing boundaries. Nevertheless, a number of border disputes have troubled the relations between states which accept in principle the status quo. These disputes concerned disagreements about the interpretation of documents delimiting the border and the exact location of the border on the ground. Such disputes erupted from time to time. A few were resolved, some were simply discontinued without a solution being devised, and some continue to disturb relations between neighbors.

This record raises the question why some states adopted irredentist policies, and why other states advocated adherence to the status quo? The argument that irredentism was caused by nationalism still leaves unanswered the question why are some states more nationalistic than others? The advocacy of the status quo cannot be explained merely by the states' inclina-

The research on which this paper is based was made possible by grants from the Social Science Research Council (in 1966) and the Center for International Affairs, Harvard University (1967). 
tion to preserve what they have. There is another side to the advocacy of the status quo, namely, that states refrain from claiming territory from their neighbor. The explanation that the majority of states are "satisfied" and therefore accept the status quo is also not sufficient. There remains the question why are they "satisfied"? Their boundaries have been imposed like other African boundaries, and they cut across tribes and ethnic groups like most African boundaries do. Nor is it clear what prompts two states to engage in a border dispute, and then after a period of bickering to resolve the issue by a compromise that they could have reached long ago, or to drop the matter as if it had never existed.

Answers to these questions can be sought by a number of approaches. One is to consider the influence of the domestic and international environments upon state behavior. Another approach would emphasize personalities and the decision-making process. The discussion which follows is based mainly upon an assessment of the environmental factors. Fully satisfactory answers to the questions posed above would probably require more extensive consideration of personalities and of the decision-making process, but unfortunately the information available on these two factors is incomplete and uneven. I hope that nevertheless the answers suggested here will go some way toward explaining the main policy trends on boundary and territorial problems. They also provide illustrations of the links between the domestic and international political systems.

The use of the terms "status quo" and "revisionism" in describing states' attitudes calls to mind numerous examples of states which have adopted one attitude or another to the political settlement emerging from a war or conflict. In such cases, support for the status quo was associated with the desire of the victors to protect the fruits of their victory, and revisionism reflected the desire of the losers to avenge the injury to the national "self". The status quo and revisionist attitudes examined in this study occurred in an entirely different context. Our study concerns the attitudes of newly established states to the territorial framework which gave them life as states. It involves interaction among heterogeneous states. Few of these possess a national identity which has deep roots; in the 
majority of these states an image of self-identity is only beginning to form. Unlike the revisionism of old-established states, which often fed on a long record of enmity and rivalry, and took the form of direct collision between neighbors, the resentment of the revisionist African states was directed in part against the former colonial master, and was tempered by an ideology of solidarity with African neighbors. Revisionism among older-established states was often associated with a competition for power and influence between the parties, whereas, in Africa, the issue was usually a more narrowly territorial one.

In the search for clues or answers, it is tempting to attribute revisionist policies to states which have adopted a radical ideology, and status quo policies to conservative states. However, no such correspondence existed in fact. Among the revisionist states we find Morocco, which was generally regarded as pursuing a conservative policy both domestically and internationally. Somalia and Togo were also not known for their revolutionary radicalism. Algeria, on the other hand, which prided herself on her radicalism in both domestic and international affairs, was among the staunchest advocates of the territorial status quo and of the sanctity of the boundaries imposed by the colonial powers. Ghana under Nkrumah was the only example of radicalism and territorial revisionism coinciding. Since generally no such coincidence existed, explanations for the conduct of states should be sought in other directions. ${ }^{2}$

One obvious course of inquiry would be to consider the boundaries themselves. Can the presence or absence of conflict be explained by the "artificial and arbitrary" nature of the boundaries? To what extent can we attribute state policies to the boundaries cutting across ethnic groups and communication lines, and interfering with economic activity?

Implicit in the argument that it is the boundaries which cause conflict is the assumption that the location of borders in relation to the facts of economic or human geography is by itself a major factor in international politics. In other words, the boundaries themselves can be "good' or 'bad', conducive to peace or to conflict. This approach was very common 
in the literature on international politics in Europe during the first half of this century. It was expressed eloquently by Lord Curzon, who said that borders are the "razor's edge on which hang suspended the modern issues of war or peace", and that borders had an "overwhelming influence" in the history of the modern world. ${ }^{3}$ This is essentially a geopolitical approach to international politics and, as such, is deterministic in character.

Without denying the influence of the "objective" factor of the location of the border, it should not be ascribed too great a weight as compared to other factors influencing the behaviour of states. No doubt, the Somali tribes' need to cross annually the border from Somalia into Ethiopia for grazing, and friction between these tribesmen and the Ethiopian authorities, have contributed much to the conflict between the two states. But arrangements for grazing for the tribes could have been made without the issue becoming a major territorial dispute. Somalia, however, chose to pursue irredentism, and did not seek a solution through arrangements to facilitate transfrontier grazing. Similarly, the dispute between Mali and Mauritania cannot be explained solely by reference to the location of the border, which was inconvenient to the nomadic tribes which had to cross it in pursuit of their livelihood, and clashed in the process with the inhabitants and authorities on the other side.

More basic reasons, from the realm of politics rather than geography, should be sought to explain these and other border disputes. This is not to deny the influence of the geographic factor. The existence of a border which imposes hardships on the population probably influences the formation of ideas and concepts which determine state behaviour. But this is only one factor among many, and by no means the most important.

\section{The status quo and the quest for legitimacy}

What are the internal sources of status quo attitudes? The most outstanding feature of the internal structure of most African states is their lack of a cohesive integrated society. In 
most cases, the state was not built by the national society. The state was antecedent to the nation, and the state's framework, both territorial and administrative, was formed during the colonial period. The national society, through the nationalist movement which sprang from it, won independence and took over the pre-existing state. The colonial boundaries were part of the framework which defined the state and which holds it together.

Thus, in a sense, the state was defined by its boundaries, and the self-image of the state became associated with the colonial borders. The association between the states' definition of the "self" with the colonial boundaries is exemplified by the disputes concerning boundaries which had been altered during the colonial period. Both Togo's irredentism and Cameroun's claims aimed at the restoration of the boundaries as they were during the German period. Boundary changes during the colonial period contributed to the Somali disputes and the MaliMauritania dispute, and inspired claims by Egypt against the Sudan, and by the Congo (Brazzaville) against Gabon. Tanzania's demand for the alteration of her boundary with Malawi was preceded by the spread of a myth among Tanzanians, according to which Britain had moved the border after the first World War from the middle of Lake Nyasa to the Tanzanian shore. 4 To be sure, not all boundaries which were altered during the colonial period became subject to dispute, but boundary changes led in several cases to uncertainty about the "self".

The boundaries could be likened to the external shell of the state. Since the majority of states had not yet attained internal cohesion, it was in their interest to preserve this shell intact. In many cases, the maintenance of the status quo came to be associated with the self-preservation of the state. It was feared that, were the right to secede granted to any group or region, it could stimulate secessionist demands from additional regions or groups, and could threaten the disintegration of the state. Secessionist movements of varying importance had sprung up in many states: the Congo (Katanga and Bakongo), Ethiopia (Somalis and Eritrea), Ghana (the Ewes), Ivory Coast (Sanwi), Kenya (Somalis and the Coast), Mali (the Touareg), 
the Sudan (the negro south), Uganda (Buganda and Ruwenzururu), and perhaps others. The current war between Nigeria and Biafra is another tragic illustration of such problems.

The interest of states in preserving the status quo is reflected also in the qualms many states have about annexing regions or tribes from neighboring states. The annexation of a population could increase the weight of a tribe or group inside the country, and could thus upset the existing political relationships inside the state. The "tribal balance" is often a matter of concern to the political leaders, and any change in the composition of the state could lead to internal conflict. Thus, internal political considerations were an important factor behind the Nigerian government's opposition to proposals of some Action Group politicians for the annexation of the Yoruba-populated area of Dahomey. Similarly, the cautious policies of Gabon and Cameroun regarding the future of Rio Muni are partly motivated by their reluctance to incorporate additional Fang into their respective states.

Since any boundary change could undermine their precarious internal structure, and perhaps even threaten their existence as states, it is understandable that most states consider it to be in their interest to preserve the status quo.

Yet this interest of states in the preservation of the status quo was inconsistent with the anti-colonial nationalist ideology current in Africa. The prevailing ideas and values among nationalist leaders at the time of independence predisposed them to a critical attitude toward the international borders which their states inherited. Their anti-colonial nationalism led them to resent the arbitrary impositions of colonial rule, and the borders were among these. For those who wished to abolish the entire colonial legacy, a logical corollary would have been to reject also the colonial borders. The myth of precolonial unity, and the pan-Africanist aspiration for unity, also pointed to the rejection of colonial borders.

Advocacy of the right of self-determination (a corollary of anti-colonial nationalism) could also have led to the rejection of colonial borders. It is very significant, therefore, that most African interpretations of the right of self-determination, and in particular who is entitled to it, differed markedly from 
some interpretations held in Europe about the right of "nations" to self-determination. As Rupert Emerson has pointed out, most African leaders, like most colonial nationalists, chose to interpret this right as applicable to the colonial territory as a whole, within the inherited boundaries. No section of the population, however defined, was entitled to this right, ${ }^{5}$ But, despite this interpretation of self-determination, the prevailing ideological climate in Africa was revisionist.

The immanent fragility of the new states was thus accompanied by the added weakness of a revisionist ideology. In order to lessen their vulnerability, states were therefore impelled to seek new ways to establish their legitimacy or, to borrow Rousseau's oft-quoted phrase, to transform "strength into law, and obedience into duty".

In Europe legitimacy was for a long time derived from the dynasty ruling the state. In the nineteenth century, nationhood began to be accepted as the legitimizing principle, and is still widely regarded as being so today. Yet African states are neither nation-states nor dynastic-states: most of them cannot avail themselves of nationhood as a legitimizing principle, nor are they legitimized by the dynastic principle.

In the insecure and precarious situation of the new states the absence of a legitimizing principle was an added weakness. It rendered insecure not only the government but also the existence of the state. But, whereas the government could justify in the short run its position and authority by its having come into power through the efforts of the nationalist movement, the existence of the state and its territorial extent could not be legitimized in the long run by this device.

The need of states to define themselves by colonial boundaries led the majority of them to the realization that they had a mutual interest in establishing respect for the status quo. Since most states are vulnerable to external incitement for secession, it was obvious to the majority of states that reciprocal respect for the boundaries, and abstinence from irredentism, would be to their advantage. This principle, which at first was accepted by tacit agreement, calls to mind the formula of the Peace of Augsburg in 1555, except that, in contemporary Africa, nationality and not religion was at issue: cuius 
regio, eius natio, or whose the region, his the nation. The subsequent transformation of this tacit agreement into an established norm raised a number of problems.

Since most newly independent states in Africa were successor states, a possible way to legitimize the state and the extent of its territories was by recourse to the principle of state succession as recognized by classic international law. Traditionally, boundary treaties and territorial agreements were regarded as being "dispositive" and, as such, were unaffected by changes in sovereignty, regardless of whether the new state entered into a devolution agreement formally accepting the treaties concluded by its predecessor.

However, classic international law was regarded by the new states as a tool used by the imperialist powers to defend their predominant position, and the law of succession did not accord well with nationalist ideology. Many influential Africans considered it distasteful and ill-fitting to invoke the status of successors and inheritors of the colonial government in justification of the existence of states and their rights over territory.

Legitimization by classic international law or merely by the principle of "succession" being unpalatable, the new states sought to establish the principle of the preservation of the territorial status quo through a new system of international law, constructed by the new states themselves. The process of constructing a new system of international law was, naturally, accompanied by sharp controversies between differing viewpoints, the clash between status quo and revisionism often occupying the center of the stage. Its crowning achievement was the resolution of the OAU Heads of State Conference in July 1963, pledging the member states "to respect the borders existing on their achievement of national independence". 6 Thus, the relative security to be found in the preservation of the status quo and the search for a legitimizing principle to consolidate the existence of states converged in the legitimization of the status quo. 


\section{Revisionism, internal structure and ideology}

From the above analysis, attributing the support for the status quo to the precarious internal structure of states and their quest for legitimacy, it follows that the revisionist states were under no such compulsion. As we shall see, revisionism was justified by resort to other legitimizing principles-ethnic nationhood, history and anti-colonial ideology.

Somali irredentism is based on an ethnic-cultural nationalism resembling. European nationalism. Somalia is a somewhat exceptional case among African states, because it is a nationstate. There is a much stronger sense of national consciousness, and Somalia is much less threatened by disintegration than the majority of African states. Not being as fragile or open to disruptive challenges as the other states, she is not open to the same inducement or pressure to accept the norm that colonial boundaries must be respected. The legitimizing principle of the Somali state is Somali nationhood, and not the norm of reciprocal respect for the status quo.

Another irredentist state, Morocco, claimed territory from Algeria and wished to annex Mauritania on the grounds of historic rights. Morocco argued that her historic borders were violated by French colonialism, which usurped part of her national territory. Moroccan irredentism, like Somalia's, can be explained by the fact that she too can afford to ignore the norm of respect for existing borders. The existence of the Moroccan state is legitimized by the principle of the continuity of the historic Moroccan state, rather than by colonial boundaries or a nationalist movement. In this sense, Morocco too is an exception among African states, possessing a legitimizing principle which others do not have.

It is perhaps fortunate that only a few of the contemporary African states can trace their statehood to pre-colonial times. Streaks of irredentism can be discerned in other historic states as well, although it did not develop to the same extent as in Morocco. Egypt has displayed ambitions toward the Sudan. These can be seen in the light of the historical fluctuation of Egypt's southern border, reflecting the millennia-old urge to control the upper Nile. Tunisia's territorial claims are some- 
times justified by reference to Tunisia's historical boundaries.

Liberia and Ethiopia, perhaps because of their heterogeneity, have become ardent advocates of the status quo. Until $195^{8}$ Liberia demanded the restoration of territories which, she claimed, had been usurped by Britain and France. Ethiopia's claim to Eritrea and to Somalia after the Second World War were justified on historic grounds. But since the early $19^{60}$ 's, Ethiopia has been amongst the most ardent advocates of the status quo. Ethiopia's conversion to the status quo was facilitated by the absence of grievances depicting Ethiopia's borders as imposed and unjust. The proud tradition of the Ethiopians, who were taught that the boundaries established in the nineteenth and early twentieth century should be regarded as an achievement of Ethiopian diplomacy in its struggle against colonial encroachments, also contributed. But another explanation of Ethiopia's adherence to the status quo is that, although a historic state, Ethiopia lacks cohesion, and is far more heterogeneous and fragile than Morocco. Ethiopia benefits from the reciprocal observance of the status quo, and would only expose herself to greater dangers by rejecting it. Liberia's policy was probably motivated by similar considerations.

The Ghana-Togo dispute is more complex. At its origin was the ethnic nationalism of the Ewe, divided between the British and French jurisdictions, and demanding the unification of the Ewe people. When it became doubtful that the ethnic justification could advance their case in the United Nations, the Ewe leaders redefined their aspirations as the re-unification of the two Togolands. The main vehicle for this became the Togo Republic, and its irredentism came to be justified by a historic argument, the restoration of the boundaries as they had been during the period of German rule.

Togolese irredentism boomeranged, as it helped to provoke a Ghanaian counter-claim. Ghanaian irredentism can be viewed as a defensive reflex against Togolese claims, and also as an expression of the Ghanaian government's commitment to an anti-colonial pan-Africanist ideology. The Ewe and Togolese claims were, of course, a serious threat to Ghana's territorial integrity, and her desire to integrate the former 
British Togoland into the Ghanaian state. Given the intensity of the Ghanaian commitment to the pan-African ideology, Ghana could not respond to the Togolese challenge by proclaiming the sanctity of colonial borders. Instead, Ghana chose to counterattack, arguing that the best means of achieving Ewe and Togolese unity was by their joining Ghana and becoming part of it. The annexation of the Togo Republic by Ghana had in Ghanaian eyes the double advantage of removing the threat of a Togolese irredenta, and of being in accord with pan-African ideology. As Ghana saw it, this would have been a step toward the abolition of the colonial legacy, and toward the greater unity of Africa.

There remains the question how to explain Ghanaian irredentism toward the south-east corner of the Ivory Coast, and the absence of claims along the rest of Ghana's borders. It seems plausible to attribute this to a combination of factors. One was the availability of the Sanwi separatist movement in the Ivory Coast, which offered itself to exploitation. Another was Nkrumah's Nzima origin, and the ethnic links between the Nzima and Sanwi.7 The third factor was the fundamental political antagonism between Nkrumah and Houphouet-Boigny. And finally, pan-African ideology provided justification for altering the colonialist boundaries, and thus "reuniting brothers separated by colonialism".

The dual source of Ghanaian revisionism, in pan-African ideology and Ghanaian state interest, is reflected in a White Paper explaining the 1960 constitution. According to the White Paper, the constitutional provision for surrender of sovereignty was intended to facilitate "the entry of Ghana into a union of African states ..." and also "to enable peoples who are at present outside Ghana but who are linked by racial, family and historical connections with Ghanaian peoples to join them in one integrated state". ${ }^{8}$

\section{Inconsistencies: Regimes and personalities}

Pressures and constraints imposed by the internal structure of states help to explain some general attitudes of states bo boundaries. But they do not suffice to explain numerous actions 
and events which deviate from apparent patterns or established principles. States do not always act on principle. They may pursue contradictory goals or may be tempted into actions which run contrary to the principles they espouse. Furthermore, policies are not pursued at an even pace; irredentism may rise or subside. States which in principle accept the status quo may become involved in a bitter border dispute with a neighbor. Or they may lend assistance to secessionist movements, despite their being aware that such acts tend to disrupt confidence and may boomerang to damage their own security. Wherever men act, such inconsistencies are to be expected.

It is doubtful whether a meaningful general theory to explain such inconsistencies can be devised. But we can examine a few factors which have influenced policies, and which provide a partial explanation of the variety of acts which seem to deviate from established patterns and principles.

A number of border disputes may have stemmed from wide and deep political antagonism between governments. Such antagonism usually had its origin in reasons unrelated to the common border. But, once relations deteriorated, and governments viewed each other with hostility and suspicion, sesondary disputes, including boundary disputes, developed. The primary conflict between the governments may have been caused by a variety of reasons: personal antagonism between leaders, competition in the African arena, support for opposition groups, and a chain of mutual suspicions and subversion against each other. The border disputes to which such relations sometimes led could have been inadvertent, merely one episode caused by a combination of suspicion, ill-will, and misunderstanding. Such disputes can be considered as mere symptoms of the relations. But, at the same time, the same dispute could also stem from a deliberate attempt by one side to exert pressure, and extract concessions in other matters. A few examples will illustrate the process.

Egypt's territorial claims on the Sudan in 1958 can be interpreted in two ways. One is to regard them mainly as a symptom of the fundamental tensions between the two countries, stemming from Egypt's age-long drive for influence over the upper reaches of the Nile, and her disappointment at the Su- 
dan's having opted for independence rather than union with Egypt. Another interpretation is that the Egyptian claims were intended as a lever to extract concessions from the Sudan on two matters on which negotiations were being conducted at the time. These were the compensation to be paid to the Sudan for the flooding of the Wadi Halfa region and for the resettlement of the local population made necessary by the construction of the Aswan dam, and the Sudan's request for a revision of the 1929 Nile Waters Agreement. Negotiations on the latter question had reached a deadlock in January 1958, a few weeks before the border dispute erupted. Of course, the dispute may have been at the same time both a symptom of underlying tensions and a move in the bargaining process.

The cause of the border dispute between Ghana and Upper Volta $(1969-1966)$ was ostensibly a disagreement over the interpretation of documents and maps defining the border. But its deeper cause should be sought in the growing antagonism between the two governments. Ghana was disappointed at Upper Volta's reversal of her rapprochement with Ghana, initiated in 1961, and at the close links Upper Volta established with the Ivory Coast. Upper Volta, for her part, suspected the Ghana government of supporting subversion against her. Within this atmosphere the two governments apparently developed a genuine difference over the interpretation of documents. This became subsequently aggravated, as Ghana tried to use the problem to demonstrate to Upper Volta her capacity to cause trouble, whereas Upper Volta used the dispute to embarrass Nkrumah by portraying Ghana as expansionist.

The Dahomey-Niger dispute over Lété island illustrates the influence of a number of factors. First, the importance of personalities. Ownership of Lété island was contested between the two sides for a number of years. But, as long as Hubert Maga was President of Dahomey, the excellent personal relations between him and Hamani Diori, President of Niger, assured close collaboration and harmony between the two states. A number of minor incidents stemming from the disputed ownership of the island did not mar the friendly relations. The fall of President Maga disrupted this harmonious relationship. Niger began to suspect the new Dahomey regime 
of aiding the subversive Sawaba party. In these circumstances, long-standing tensions over the presence and prominence of Dahomans in the civil service and in the employ of private firms in Niger, and over Dahomey's position astride Niger's communications with the world, began to embitter relations between the two states. The vehemence of the dispute over Lété island was merely a symptom of the antagonism which developed between the two governments.

The dispute between Tanzania and Malawi also seemed to be a symptom of the political antagonism between the two governments. The location of the Tanzania-Malawi border on the Tanzanian shore of Lake Nyasa was long resented by Tanzania. Yet Tanzania accepted the border. In fact, the 1964 $\mathrm{OAU}$ summit resolution pledging respect for existing boundaries was introduced by President Nyerere. The demand formally raised by Tanzania in 1967 to move the boundary to the middle of the lake can be regarded as merely another expression of the antagonism which had been developing between the two governments since 1964 . Had relations been better, it is possible that Tanzania would not have demanded the modification of the border. Instead, it would probably have been possible for the two governments to agree on practical measures to enable the inhabitants of the Tanzanian shore to use the lake.

To the extent that relations between states depend upon the sympathy or antipathy which regimes harbor toward each other, these relations can change with the changes of regimes. As we have seen, the Dahomey-Niger dispute erupted following the overthrow of President Maga in Dahomey. But, once confidence between the two governments was restored, and Niger ceased suspecting the new Dahomey regime of aiding the Sawaba, Lété island lost its importance. A vague formula about joint ownership of the island was agreed upon, which made no advance toward solving the basic question of the ownership of the island and the location of the boundary. But nevertheless, the issue was dropped and forgotten.

A more radical change in policies occurred in Ghana, where the overthrow of President Nkrumah was followed by the renunciation of his policies by the National Liberation Council. 
The new government made special efforts to normalize relations with neighboring states, and to reassure them that Ghana harbored no territorial ambitions. ${ }^{\vartheta}$ A notable gesture was the extradition to the Ivory Coast of the leaders of the Sanwi separatist movement, who were brought to Abidjan by a Ghanaian good-will mission.

The Sudan's increased friction with Ethiopia and Chad can also be attributed to the change in the regime. During the tenure of the military regime of General Abboud, the Sudan's relations with Ethiopia and Chad were relatively smooth. But, following the revolution of October 1964, Sudanese policy changed. The Sudan's toleration on her territory of bases of the Eritrean separatist movement led to conflict with Ethiopia, and the permission for a Chad government in exile to be formed in the Sudan produced friction with Chad.

In general, changes in the regime of a state influenced attitudes to borders and the course of disputes in two ways. First, as in the case of Ghana, the change in the regime brought about a change in the ideology of the state, its norms, and the concepts of legitimacy which it sought to advance. This opened the way toward a solution of the disputes. Theoretically, the reverse could also happen: the installation of a new regime may be followed by the adoption of an ideology inimical to the status quo, and lead to the eruption of border disputes. Secondly, changes of regime produced antagonisms and suspicions among neighboring states, and thus brought about the eruption of border disputes. The reverse, a change of regime leading to the restoration of confidence, produced an atmosphere conducive to the disappearance of disputes, either by their solution or by their being simply removed from the agenda.

Pressures of domestic politics must also be considered. Pressure groups expressing African economic interests are not much developed. Yet tribal interests are often of primary im portance in African politics. The delicate balancing of tribal interests in each state has apparently exercised a moderating influence, restraining governments from embarking upon irredentist policies which might upset the existing tribal balance or which might expose the government to charges of tribalism. 
Nevertheless, in some instances it is possible to discern tribal influence upon boundary policies. In the Somali case, the Darod tribe has occasionally criticised the government for not pursuing Somali territorial claims vigorously enough. The Darod's special interest in these claims can be explained by the dependence of sections of the tribe upon grazing and water in Ethiopia, and by the fact that the annexation of the Somali-inhabited portions of Ethiopia would increase the numbers and weight of the Darod in the Somali Republic. Darod criticism of the government was usually expressed in the context of the continuous rivalry between the Darod and the Hawiya tribes over their share in the government, and was only one of several issues raised in the controversy. ${ }^{10}$ The effect and influence of such criticism upon government policies is difficult to gauge.

As I. W. Zartman observed, tribal interest may have played a role in a few other cases as well. In the Mali-Mauritanian dispute the grievances of Malian frontier tribes might have been a factor influencing Mali's policy; Nkrumah, a Nzima, supported the movement of the related Sanwi people aiming to secede from the Ivory Coast, and Olympio, an Ewe, espoused the reunification of Togoland.11

It is common to attribute aggressive foreign policies and external involvement of states to the desire of governments to divert attention from their shortcomings, and to discipline public opinion in the face of an "enemy". It seems that such considerations contributed to a few border disputes.

In Morocco, pressure from the Istiqlal can be regarded as a factor that influenced King Mohammed $V$ to adopt irredentism as a state policy. When Alal el Fassi launched his irredentist propaganda in $195^{6}$, the King at first ignored it. Only with the growth of domestic opposition did the King embrace irrendentism, perhaps as a diversion or a device to unite the nation in the face of an external enemy and to diminish internal dissension. ${ }^{12}$ Later, the antagonism between King Hassan II and radical political groups, and the King's consequent political difficulties, may have been one of the factors which influenced the Moroccan government to pursue vigorously her territorial claims against Algeria in 1963. Such 
considerations may have influenced some actions of Somali governments. According to A. A. Castagno, when the Somali government was threatened by a no-confidence vote in the National Assembly in April 1962, it was saved in part by "the mounting acrimony between Ethiopia and the Republic, to which the Premier responded vigorously".13 Similarly, the exuption of serious fighting along the Somali-Ethiopian border in January and February 1964 has been attributed by commentators to the proximity of the general elections in Somalia. Domestic politics may have played a role in the occasional spurts of Tunisian boundary claims. The vehemence of the Dahoman position in the dispute with Niger in $196_{3}$ was apparently linked with the need to suppress discontent over the overthrow of President Maga, which flared up in the north of the country.

Yet, in view of the internal difficulties which African governments often face, it is interesting that border and territorial disputes were not more frequently initiated or aggravated for domestic political reasons. There are two explanations for this.

One is ideological. The sentiments of pan-African solidarity exert a moderating influence upon inter-African relations. On the other hand, the role of an external enemy to which attention can be diverted from internal problems is performed by "imperialism" and "neo-colonialism". It is significant that in some territorial disputes, African governments blamed the former colonial power, and emphasized the colonial origin of the problem, rather than accuse the neighboring African state of responsibility. Both Morocco and Tunisia initially blamed France for usurping and dismembering their territories. Somalia blamed Britain. Only subsequently were accusations levelled at the neighboring African government, but they remained tempered by references to the primary responsibility of the colonial power. Such an apportionment of blame accorded with pan-African ideology, and helped maintain ideological consistency.

Without underestimating the effect of the ideology, it seems reasonable to add a second explanation for the fact that African states seldom resont to border disputes as a diversion 
from domestic difficulties. This is one of expediency. Experience has indicated that quarrels with neighbors can be dangerous, because the territory of the neighboring state can become a base for the opposition and for organizing subversive activities against the government. Thus, instead of diminishing internal pressures, border conflict with a neighbor may stimulate external support for the domestic opposition, and thus strengthen them. For this reason too, neighbors are better left in peace.

The main conclusion from the foregoing discussion is somewhat paradoxical. It seems that domestic fragility and the resulting latent political instability of most African states has been a factor conducive to caution in their relations with neighboring states. On the other hand, relative cohesion, ethnic, traditional or ideological, has enabled states to pursue irredentist policies. Thus, paradoxically, domestic instability was a factor promoting stability in inter-state relations, whereas relative domestic stability has enabled states to pursue policies which had a de-stabilizing effect on the international scene. 


\section{Kenneth W. Grundy}

\section{The "Southern Border" of Africa}

There is no question that there is a significant division between independent black' Africa to the north and colonial and white-dominated Africa to the south. But to locate that division precisely and graphically, and to describe it accurately with regard to its nature, importance, and stability is open to a great deal more debate.

The concept of "border" in this paper will not be treated in characteristic geographical terms, for the "border" with which we are dealing is not strictly a geographical phenomenon. Although we are concerned about "natural frontiers" and topography, and although we are interested in the ethnic patterns over which political boundaries have been superimposed, the existence and character of the border we shall describe will emerge residually, i.e. as a by-product of our primary concern with the growth and analysis of two separate groups of states in the southern portion of Africa.

Because the sets of relationships we shall describe are fluid, embryonic, and incomplete, the border dividing them is amorphous, permeable, and analytically elusive. In fact, some observers might argue that it is incorrect to view the division between black-dominated and white-dominated Africa as a border at all. This problem shall be dealt with after we have had an opportunity to survey that division in more detail. Likewise, the inter-state relationships we are dealing with may not

The author is grateful for research funds made available by the Rockefeller Foundation of New York and by the Department of Political Science and Public Administration, Makerere University College, University of East Africa. Neither group is in any way responsible for the opinions that follow. 
appear to possess all the criteria necessary to merit the title of "system". A system, in the analytical and descriptive sense, implies a measure of completeness, independence of other systems, and internal inter-dependence among the components. Rather, the terms "subsystem" or "subordinate system" might be more accurate. The difficulties of this terminology as applied to Africa are easily apparent.

Since systems, in the inter-state sense, are comprised of nation-states, naturally the systemic divisions we shall describe will coincide with state boundaries. But the matter is not so simple, particularly when one seeks to categorize each state along the frontier into one or the other set of relationships. First, some states might conceivably wish to avoid commitment or involvement in either system, and thus might seek to play the role of an independent actor, or even of a buffer or mediator (either by choice, by necessity, or by imposition through perceived limitations of alternatives). Between two systems or embryonic systems might be found a state or states which seek to travel alone, or others which may travel, so to speak, in both systemic orbits.

A second way that analysis may be complicated is because of the obvious fact that the systems we are examining are, in fact, incomplete, and thus not fully or even fundamentally separate and independent units. A component effectively identified with one system, largely on the basis of one or a few criteria, may also be identified with another, perhaps even a rival system, if different criteria are used. For example, a state may be economically within one system and yet politically or diplomatically integrated into another system. Or a state may be geographically surrounded by states which are members of system A, and yet feel ideologically devoted to principles espoused by members of system $B$. One could imagine that this would be a rather common occurrence in inter-state relations and one that particularly emerges in the relations between the new states.

Another problem of analysis emerges from the very fluidity of state behaviour. How much should the shift in trade directions or diplomatic behaviour be regarded as a movement away from one system towards another? In a situation as plastic as 
inter-state relations in southern Africa, it would be wise to look for long-term trends and even short-term fluctuations as well as to search for the catalytic factors precipitating change.

The collective political boundaries we shall hereafter refer to as the "southern border" of Africa need to be viewed from many angles. The analyst is expected to be something of an economist, political scientist, geographer, sociologist, and military strategist. He must also combine the skills of an academician, journalist, and, alas, detective. The data will be drawn from a multitude of sources-the press, government reports, interviews, and scholarly analyses. It is hoped that by drawing several threads together in a single paper, the pattern of the fabric will be more discernible.

Eleven territories enter into the succeeding discussion: the Congo (Kinshasa), Zambia, Malawi, Tanzania, Angola, Rhodesia, Mozambique, Botswana, Lesotho, Swaziland, and South Africa. To all intents and purposes, South West Africa is part of the Republic of South Africa, since it is governed from Pretoria by decisions taken by Republic officials and executed by a bureaucracy in the employ of the Republic. However, we shall especially concentrate on relationships involving states and territories along the "border". To be sure it is somewhat artificial to restrict our analysis to intra-African relationships and to omit consideration of broader, international influences. But limits of time and space necessitate some parameters that may be at once arbitrary, yet defensible.

\section{The diplomatic border}

With whom do the states in the region (hereafter to be regarded as including all states south of the Congo-Tanzania band across the continent) have diplomatic contact, and what is the nature of these contacts? Are they oriented away from neighboring states across the divide or do diplomatic relations bridge the divide? In what diplomatic institutions do the various states share common membership? Answers to these questions, although relatively easy to obtain, contribute to an understanding of the broader political picture.

All of the independent states in the region are members of 
the United Nations. Rhodesia, whose Unilateral Declaration of Independence (UDI) has not been formally recognized by even a single state, naturally is not a member. Swaziland and South West Africa are not independent, and Angola and Mozambique are ostensibly represented by Portugal. The United Nations and some of its subsidiary agencies and organs are the only important interstate institutions in which the Republic of South Africa comes into regular contact with black African states. 1

All of the independent states with territorial interests in the region are members of the British Commonwealth with three exceptions-the Congo (Kinshasa), Portugal, and the Republic of South Africa. The latter, under pressure from the African and Asian members of the Commonwealth, did not apply for re-entry when it changed from dominion to republican status in May 1961 .

Membership in the Organization of African Unity (OAU) is common to all independent states in the region, except for Portugal and the Republic of South Africa. To be sure, all are not determined and active participants in every OAU activity, but nonetheless the channels for regular contact with fellow black African states exist there and can be exploited

In terms of international organizational affiliations, it would appear that, if a "border" were to be drawn dividing white and black Africa, Angola, Mozambique, Rhodesia, and South West Africa alone would be included in the orbit of the Republic of South Africa. Botswana and Lesotho, although south of the "border", by virtue of their membership in a multiracial Commonwealth and more importantly the multiracial OAU, could be regarded as outposts of black Africa in a white-dominated South. Malawi and Zambia consequently would appear to be geographically and institutionally north of the "border".

But institutional memberships alone do not determine international alignments and systemic patterns. More reliable gauges are the various political and economic relationships that have been developing. One crude reflection of these patterns is the policy of diplomatic recognition and representation pursued by independent states. When these policies are char- 
ted, certain patterns become evident. The statuses of Botswana, Lesotho, and Malawi seem to be far more ambiguous. Figure 1 represents diplomatic relations and contacts in 19671968.

Too much should not be read into this configuration. Decisions to establish relations with other states do not always reflect the political and ideological orientation of a state. Rather they are a function of many factors, some of which are largely deterministic. First, initial diplomatic relations are largely historically determined. Newly independent states have been inclined to establish relations with the former metropole first, and then to seek other ties afterward. Second, the question of geographical location limits the range of choice. Since states usually have more economic and consular dealings with neighboring states than they do with countries farther away, it stands to reason that one would generally establish relations with neighboring states first, given limited resources. Third, it is also a matter of economics. An embassy abroad is an expensive proposition. Unless there is an absolute and recognizable need for permanent representation, why should a poor state undertake such an expenditure? However, a decision may also be reached because of certain economic advantages that may accrue to the weaker partner, either in the form of a reward for the establishment of relations in the first place or as opportunities for financial and technical assistance and trade relations open up more readily to the state with on-thespot representation. Finally, it can be a function of preference, too. A state may seek to exchange diplomatic representatives with another state as a gesture of goodwill and in an effort to improve and expand relations between the two countries. Particularly since the states of black southern Africa are so economically wanting, it would not be wise to assume that decisions regarding diplomatic representation are solely expressions of ideological and political preference.

Even bearing in mind these reservations, the "border" begins to take definitive shape. Diplomatically, two separate constellations of states exist in southern Africa. One finds expression in the Congo-Tanzania-Zambia loose combination with its growing ties to East African economic and political struc- 
Data have been secured from a number of sources, including diplomatic directories, government directories, Europa Yearbook, 1967, and Africa Annual, 1967. An effort has been made to give expression to the political "distances" between states by locating them nearer or farther from one another on the diagram, largely on the basis of a subjective appraisal of the degree of formal diplomatic friendship or hostility between them.

The numbers alongside the lines indicate the number of other countries in black Africa who have exchanged permanent diplomatic representatives with the states under examination.

Official diplomatic relations with exchange of permanent representatives

Official state mission without permanent exchange $--\rightarrow$

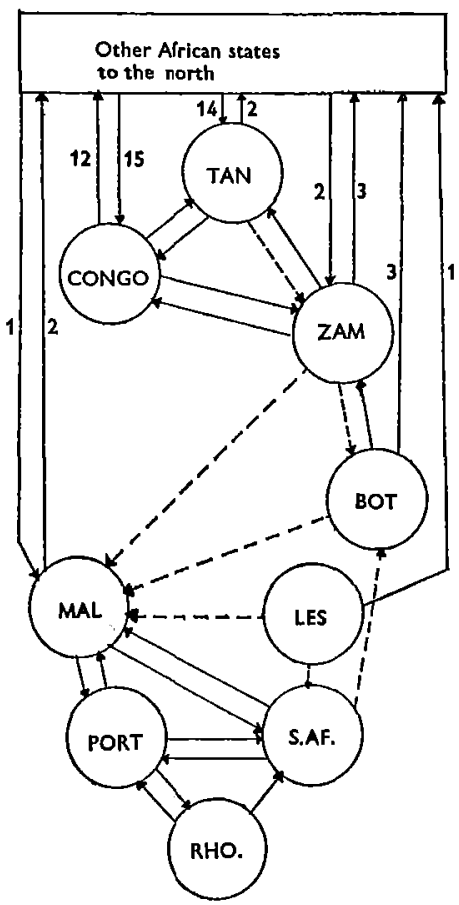

Fig. r. Diplomatic relations, $1967-1968$. 


\section{Continued from page $\mathrm{Ia}_{3}$}

tures. The other is essentially a South Africa-Portugal pole serving to attract Rhodesia, Malawi and Lesotho and to a slightly lesser extent Botswana. Figure 1 shows that in two cases states to the south of the divide (Malawi and Lesotho) have sent or received ambassadors from other black African states to the north, thereby leaping the border diplomatically. But the extent of these relations (a total of four permanent missions sent and received) does not compare with the total of 27 for the Congo, 16 for Tanzania or 5 for Zambia. Lesotho and Malwi appear to be oriented southward.

Botswana's position is more difficult to analyze, for it may well be seeking to serve as a bridge between both worlds. Botswana alone among the border states to the south has formalized diplomatic relations with a state on the border to the north. ${ }^{2}$ In fact, diplomatically, it might even be argued that Botswana is more in the northern tier than in the southern, particularly in light of its OAU and Commonwealth memberships. Moreover, Botswana has sent ambassadors to three black African states-Ethiopia, Kenya, and Somalia-reflecting a genuine desire to establish its credentials as an independent black African state. It has also been moving closer to Zambia lately. In August 1967, Sir Seretse Khama, Botswana's President, paid an official visit to Zambia, after which President Kenneth Kaunda, of Zambia, announced that his country had decided in principle to establish a diplomatic mission in Gaberones, its first south of the Zambezi. Later that month Kaunda optimistically predicted that Zambia, Tanzania, Kenya, Uganda, and Botswana might unite to become the nucleus for a United States of Africa. ${ }^{3}$

But, in other respects, Botswana seems to be unable to break out of the South African orbit. It gives every indication that it intends to establish ambassadorial level relations with the Republic.4 Its precarious economic condition grows out of an almost complete dependence upon the white-dominated states and territories that surround it. Consequently its diplomatic overtures northward at best are cautious ones, taking care not to precipitate a crisis with the Republic of South African and thereby jeopardize Botswana's economic survival, if not its very existence. The resultant foreign policy is awkward; but one 
that places Botswana more accurately in a pivotal role. This is the role its leaders envision for it, too. Sir Seretse has said that he would like nothing more than to move to bring about a rapprochement between Africa's "white south" and "black north".5 Given the economic vulnerability of Botswana, this appears to be about the best he could hope to achieve.

Both President Hastings Kamazu Banda, of Malawi, and Chief Leabua Jonathan, of Lesotho, have publicly sought to perform similar dual roles. Both have stressed the need for "peaceful co-existence" between black and white Africa, and both have called for greater economic and cultural links between the two camps. But largely because of Malawi's behaviour toward its black neighbors, and Banda's open criticism of African states that refuse to deal with South Africa and Portugal and prefer to verbally assault white Africa, Malawi has managed to alienate states to the north, thereby negating its desired role. Lesotho likewise has been ineffective in this guise. It is far more economically dependent on South Africa than Botswana and thereby has even less independence in its policies. Although many black African states have expressed sympathy for Lesotho's strategic and economic vulnerability, it seems unlikely that it can break out of the bond, even given a black government in Pretoria.

Curiously, there was a time when Kenneth Kaunda felt Zambia could maintain friendly relations with both camps. Before Zambian independence and the Rhodesian UDI, Prime Minister Kaunda at least twice suggested that an independent Zambia would be prepared to establish diplomatic relations with South Africa, provided a black Zambian diplomat were accorded the same treatment in South Africa as other ministers from abroad. 6 The UDI seems to have put an end to this line of thought, particularly as regards relations with white-minority governments. In 1968 , however, Zambia's fairly consistent position vis-à-vis the two camps was somewhat complicated when the Zambian Government sent a ministerial delegation to Malawi which called for improved relations between the two countries. The final communiqué growing out of these talks noted that Malawi would establish a High Commission in Zambia "as soon as practicable".7 


\section{Malawi's isolation from the black north}

Malawi seeks to be acceptable to both camps, but finds that its policies meet rebuff from its neighbors to the north and west. A strange combination of its economic dependence on Mozambique, South Africa, and Rhodesia, the fact of its black leadership, and its geographical situation on the "border" affords Malawi a unique position between the competing subsystems. In many respects Zambia was similarly situated, but its leaders chose to attempt to nullify Zambia's economic dependence on the south. In the space of a few years they have managed to pull Zambia out of the southern sphere of influence, even though economic patterns may still limit their maneuverability. But Malawi's economy is even more vulnerable than Zambia's and its leadership less inclined to take risks. The result has been that Malawi has taken a different approach, among black African states, in dealing with the white south, and this has served to alienate Malawi even more from the black north.

It is not easy to isolate all of the variables, or even to assign cause and effect, but one thing seems certain: Malawi's international position reflects its internal political difficulties as well as its economic dependence on the south. Zambia and Tanzania, for ideological reasons, are inclined to be critical of the regime of President Banda. So when President Banda has problems within his regime, Tanzania and Zambia have no objections to giving asylum to Banda's political enemies. This in turn strains relations with Malawi's neighbors even more, and pushes Banda further in the direction of the white-dominated areas on which he is already economically dependent. The pattern has a whirlpool effect, with each additional conflict and crisis tending to reinforce the last.

There has been a measure of conflict between President Nyerere and President Banda since their pre-independence contacts in the Pan-African Freedom Movement of East, Central and South Africa (PAFMECSA) in 1959. However, the clash became most virulent after 1964, when a number of Malawian Cabinet Ministers who had either resigned or been 
sacked by Banda were given asylum in Tanzania. This in itself would not be sufficient to strain relations between the two neighbours. However, President Banda became convinced that Tanzania went too far in its hospitality to the former Ministers Chipembere, Chirwa, and Chisiza. Banda attacked Tanzania by means of an editorial in the ruling Malawi Congress Party newspaper, the Malawi News. The editorial, headed "Tanzania Involved in Invasion of Malawi", went on to accuse Tanzania of training and financially assisting exiled Malawians who were intent on overthrowing Banda. 8

Throughout the intervening years Banda sought to document his case and in each instance Nyerere and others denied the charges. 9 Later Zambia was brought into the exchanges (although never so deeply), when Banda asserted that there had been collusion between Tanzania and Zambia.10

Relations with Tanzania were further strained in October 1965 at the OAU Heads of State Conference in Accra. A proposal by the Council of Ministers that Malawi should be a member of the OAU's Liberation Committee was blocked by President Nyerere when he bluntly stated:

Malawi is in collusion with the Portuguese in Mozambique to sabotage the work of the Liberation Committee and if it were admitted to membership, Tanzania would find it difficult to continue as a member of that Committee, knowing, as she does, that Malawi, in collaboration with Portugal, is sabotaging the work of liberation.11

Eventually Malawi withdrew its application, but the effect of this public humiliation was to push President Banda further out of the operations of the $O A U$ and in the direction of greater co-operation with his southern neighbors.

In May 1967 President Nyerere further enraged President Banda by declaring that Tanzania did not recognize the "artificial" boundary between Tanzania and Malawi which was marked along the shores of Lake Malawi. The Tanzanian Government informed the Malawian Government of its attitude and stated it would continue to recognize the original boundary which passes through the middle of the Lake. The British had changed it during the declaration of the now- 
defunct Federation of Rhodesia and Nyasaland. But it is Nyerere's position that, since Tanzania was a UN trust territory, the British had no right to do this without the permission of the Trusteeship Council. Banda flatly rejected the claim and the matter thus stands today. ${ }^{12}$

But the crucial fact is that there are three major issues dividing Tanzania and Malawi: (1) Banda's continuing diplomatic, political, and economic co-operation with the white south and his unwillingness to co-operate with the liberation movement from the north; (2) Tanzania's boundary claim on Malawian territory; and (3) Tanzania's asylum and possible assistance to Banda's chief political enemies.

There have been occasional gestures in the direction of goodwill between the two states and Malawi, but invariably they were rendered futile because of Banda's consuming fear of internal rebellion and his conviction that his most dangerous enemies were not only organizing against him from the sanctuaries in Tanzania and Zambia, but with the co-operation, assistance, and encouragement of these powers. For their part, Tanzania and Zambia could not bring themselves to be magnanimous to a man they regarded as a traitor to black Africa.

To join the majority condemning the white south would be out of character for President Banda. In his estimation, most African leaders have been "unrealistic" in their attitudes and policies toward the south. This has been reflected in Malawi's diplomatic estrangement from the north. For example, in 1966 Malawi declared the United Arab Republic Ambassador in Blantyre and his staff persona non grata, and Ghana was asked to close its High Commission in Malawi when Banda ordered the withdrawal of the Malawian High Commission in Accra. ${ }^{13}$ Banda has repeatedly called for closer economic and cultural links between white and black Africa. ${ }^{14}$ But by taking this position he knows full well that he will be regarded as "the most unpopular man in Africa".15

The resultant policies, however, follow logically from his public pronouncements. Malawi has been drifting ever closer to complete identification with the external policies of the southern subsystem. Malawi has been among the very few states 
that have opposed expelling Portugal and South Africa from various UN organs. It has abstained on questions involving mandatory sanctions against South Africa. Diplomatic relations with Portugal have been cordial. Diplomatic representatives were recently exchanged with South Africa. Agreements covering expanded trade and labor relations between Malawi and South Africa have been signed. In defence of these arrangements Banda has vigorously criticized his black neighbors and the OAU, and this has angered them even more.16

The recent call for improved relations between Zambia and Malawi, and the latter's announcement that it intended to send a High Commissioner to Lusaka, however, is not entirely inexplicable. First, Malawi has been fairly successful of late in dealing with anti-government rebels infiltrating from abroad. Zambia has repeatedly sought to assure Banda that it was not assisting Malawian rebels. Second, because of its massive transport problems growing out of the UDI, Zambia has been forced to expand its use of Malawi's facilities. Thus, the apparent understanding reached in Blantyre does not necessarily remove Malawi from the southern orbit or even indicate that Malawi is likely to diminish its warm and expanding relations with the south.

\section{The military border}

Spatial and ideological polarization along the border becomes more obvious when one considers the degree of political tensions between border states. The fundamental determinants of such hostile relations are black Africa's intention to end colonial rule and/or white minority government in the south as soon as possible, white Africa's refusal to relinquish control or retreat, and the resultant internal strife fanned by external support. This is further manifested by the mobilization and growing force levels, as states prepare to defend their territory and to forward their claims. The military hostilities discussed in the following sections are not presented to describe the wars themselves or to examine the political infighting within and among various liberation movements. Rather, our goal 
is to shed light on the international ramifications of those wars, and particularly their effects upon relations between neighboring states.

Guerrilla war in Angola. The Angolan guerrilla war has been in progress since March 15, 1961.17 But preparations for that initial uprising preceded the actual fighting by many months, and brought the revolutionary movement into con. tact with the Congolese Government as well as the Congolese Government into conflict with Portugal. Since $195^{8}$ the Uniāo das Populacoes de Angola (UPA), under the leadership of Holden Roberto, set up headquarters in the Congo and began to organize a political underground capable of functioning inside Angola. By mid-196o the UPA had established offices in Matadi, Leopoldville, and Elizabethville in the Congo as well as in the interior of Angola. Military training was first provided by a Tunisian officer serving in the Congo.

After the initial outbreak of hostilities in Luanda the theater of battle was largely confined to an area of northern Angola approximately 150 miles wide and 200 miles deep. It was to be a war of attrition. The chief task of the nationalists was to secure help from outside of Angola and to build up a military force capable of combating the Portuguese offensive as well as a political cadre able to mobilize the populace in the countryside.

It was only natural that they should turn to the Congo. Angolan nationalism first expressed itself among the Bakongo, a people that numbers some 1,000,000 in the Congo and 500,000 in Angola. During the first five years of the rebellion the bulk of the fighting was confined to north-west Angola, where the Bakongo are concentrated. And the Portuguese, although they could not hope to wipe out the rebels completely because of the latter's easy passage into and out of the Congo, were able to concentrate their forces in the region and to contain the war (see Figure 2).

One year after the opening of hostilities, Radio Lisbon was forced to admit that Portuguese forces were unable "to completely close the frontier".18 Indeed so thoroughly had they failed that by 1967 well over 400,000 Angolan refugees were to 


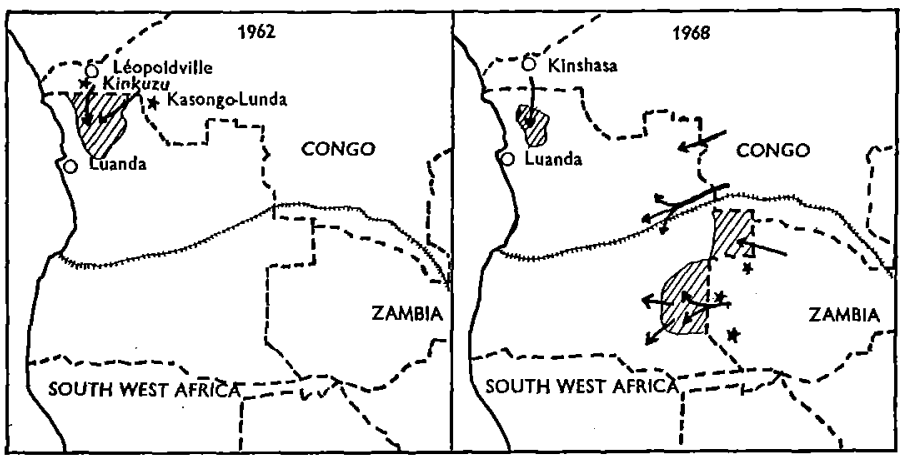

Fig. 2. Areas of fighting and infiltration, Angola, 1962 and 1968. Suspected training bases $\star$; areas of intense fighting $/ I I I I /$.

cross that frontier on their way to asylum in the Congo. Congolese assistance to the nationalists added to Portuguese counter-insurgency problems. As if to rub salt in Portugal's wounds, the Congolese blatantly announced in August 1962 that they were giving aid to the Angolan rebels, and what is more that they had "donated" a guerrilla training base at Kinkuzu near Thysville to the insurgents. The recruits were even wearing hand-me-down ANC uniforms and using weapons supplied by the Adoula Government.19 Angolan officers returning from incombat training with Algerian nationalists (sent via Tunisia) were to train recruits. 20

For a while it looked as if Portugal might move to break off diplomatic relations with the Congo. The Congolese brusquely rejected a formal Portuguese request for an explanation by frankly admitting collaboration with the rebels. Portugal's Overseas Minister, acting as if his alternatives were limited, merely responded by criticizing the "privileged sanctuary" in the Congo and by hinting that Portugal might ask its military forces to pursue fleeing raiders into the Congo and destroy their bases. 21

It was not long, however, before the Portuguese secured the means by which they could put pressure on the Congolese Government. As the Congolese secessionist province of Katanga fell to UN and Central Government forces early in 1963, 
hundreds of Katangese gendarmes and a few mercenaries in the employ of Moise Tshombe fled into Angola, where the Portuguese provided them with shelter and food. Despite repeated Congolese protests, one high Portuguese official reasoned: "The Congo is openly providing a military base for operations against us. Morally we are certainly justified in maintaining mercenaries and gendarmes on our soil." 22 By the summer of 1964, over 2,000 Katangese gendarmes were encamped in Angola. Although the Portuguese repeatedly assured the world that the gendarmes and mercenaries were unarmed and would not be permitted to return to the Congo, Colonel Jean Schramm, who headed the small group of mercenaries there (as he did at Bukavu in 1967 and later in Rwanda) promised his men that they could march on Katanga when the UN forces left.

In 1963 the Congolese Government and the OAU granted de jure recognition to the Government of the Angolan Republic in Exile (GRAE), an act that under international law Portugal could interpret as hostile. It became quite clear that Congolese assistance to the rebels kept the war smoldering.

The year ${ }_{1964}$ marked a turning-point in the rebellion. In July, Moise Tshombe came to power in Léopoldville and almost immediately the GRAE found it more difficult to conduct business in Léopoldville. Tshombe did not attempt to suppress Angolan revolutionaries. Rather he sought to suffocate them. The GRAE received less co-operation from the authorities, its military activities on the border were more constricted, and this in turn led to greater political struggle within and among the nationalist movements. Personal, ideological, and tribal differences became more pronounced and this took its toll on the fighting effectiveness of the insurgents.

This was just as well for Tshombe, for he wanted to make his peace with the Portuguese without losing too much influence in his own country and among his fellow Africans. 23 It was not until Tshombe's removal in October 1965 that the rebellion regained its momentum, and this section of the "southern border" became easily penetrable once more.

The rebellion had become immobilized by the internal unrest in the Congo, coupled with the sheer weight and concen- 
tration of Portuguese military power. A new effort and perhaps a new front were needed. In 1966 and 1967 they were supplied. A raiding party from Agostinho Neto's Movimenta Popular de Libertação de Angola (MPLA) attacked Portuguese forces in Cabinda, north of the Congo River. Holden Roberto's forces revitalized the war in the north-west. Then Angola was invaded across the Zambian and Katangese frontiers. There was even a lively flare-up around Luanda itself. The border, once more, thanks to sympathetic Congolese and Zambian Governments, had been allowed to become an instrument for guerrilla warfare, and for the first time, Portugal was forced to disperse its troops.

Vigorous pursuit of insurgents across Zambian and Congolese borders has been a tactic more frequently employed by the Portuguese of late. ${ }^{24}$ In 1967 two additional charges levelled against the Portuguese by the Congolese Government reflected tensions along the border. In June, the Portuguese and Spanish were accused of a plot to sabotage the Congolese economy by destroying the electrical lines and railway line running through Katanga. The unsuccessful saboteurs allegedly entered Katanga through Angola. ${ }^{25}$ A more bizarre report was made public in November, when two groups of armed white mercenaries (from 100 to 200 in all) allegedly entered Katanga near the railway line. They stole lorries, drove to a railway station, where they commandeered a train, and headed toward Lubumbashi. About 150 miles along the line they came into contact with ANC forces, and although no fighting apparently occurred, the mercenaries retreated back' into Angola. ${ }^{26}$ Portugal stoutly denied that these mercenaries had come from Angola. But it did concede that 75 of them had taken refuge in Angola after leaving the Congo.

The flare-ups of the past two years have led to a break in diplomatic relations between Portugal and the Congo (October 1966), and to Congolese complaints being filed against Portugal in the UN Security Council on two separate occasions (September-October 1966 and November 1967 ). The war is by no means faltering. It has increased in intensity and expanded territorially along the border.

Although the chief desire of Angolan nationalists is to end 
colonial rule in Angola, there is no evidence that the new attacks have been orchestrated by a co-ordinated leadership. On the contrary, at least three different organizations are involved. The GRAE carries the brunt of the fighting in the northwest. The MPLA is responsible for the new fronts in Cabinda and along the eastern frontier with Katanga and Zambia. UNITA, led by Jonathan Savimbi and based in Zambia and the eastern Congo, has been successful along the rail line to Lobito. Perhaps this may just be a contributory factor in keeping the Angolan segment of the "southern border" markedly unstable for many years to come.

However, the success of UNITA guerrillas in temporarily cutting the Benguela railway in March 1967 led to a crisis in Zambian-UNITA relations. Zambia, under pressure to export its copper, felt compelled to refuse to renew Savimbi's residence permit and that forced him to move to Cairo. Likewise the Kinshasa Government has sought to persuade guerrillas (mostly the GRAE) to leave the railway open. So relationships of groups and states along the sensitive border are subject to economic pressure and rapid change.

Guerrilla war in Mozambique. The Mozambican rebellion officially commenced on September 25, 1964, when guerrilla units that had crossed the Ruvuma River between Tanzania and Mozambique attacked Portuguese military installations. ${ }^{27}$ However, actual military operations were preceded by years of planning and organization by the Frente de Libertação de Moçambique (FRELIMO), a coalition of nationalist parties in exile, put together in 1962. Dr. Eduardo Mondlane, its leader, worked hard to secure unity in the movement (still not totally unified today) and was able to gain the support of the $\mathrm{OAU}$ at its Addis Ababa meeting in May 1969. Then began the difficult task of political and military organization inside Mozambique as well as training and financing operations from outside. But careful preparations paid handsome dividends. Although the Portuguese had since 1961 expected an assault from Mozambican nationalists in Tanzania, they were unable to uncover FRELIMO's military cadres in the Cabo Delgado, Niassa, and Tete provinces. Unaware of the details of FRELIMO's military preparations, the Portuguese decided to 


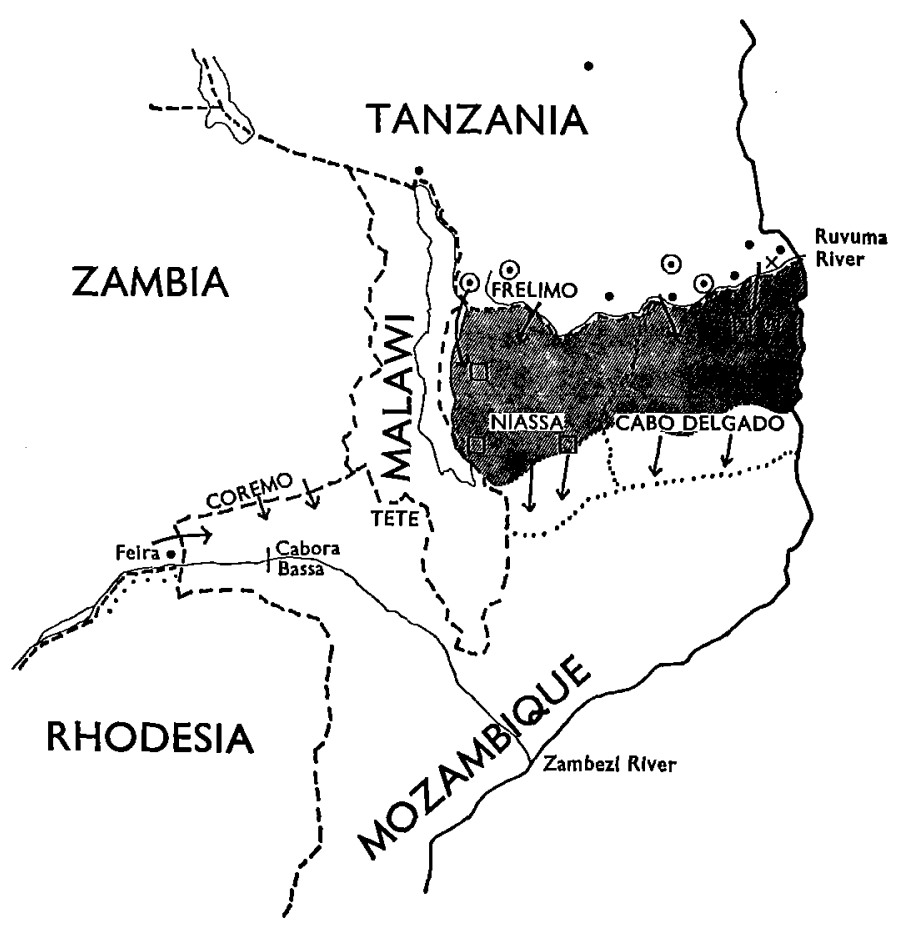

Fig. 3. Areas of fighting, infiltration and training, Mozambique. Rebel training camps $\bullet$; rebel training camps allegedly with Chinese instructors $\odot$; isolated Portuguese garrisons $\square$; rebeldominated areas $/ \mid I / I I I / I$; $1966-1967$ mining incidents $\times$; rebel raids

defend the 500-mile Ruvuma River frontier, a physically demanding assignment. They concentrated on training volunteers, constructing landing strips, new roads, and modernizing their armed forces in the region. But still the initiation of hostilities caught them off guard.

After more than three years of fighting the war is going well for the rebels (see Figure 3). FRELIMO is reasonably united. About $80 \%$ of its military training is carried out in Mozambique. ${ }^{28}$ In 1966 the guerrilla general staff moved part of its headquarters from Tanzania to Mozambique. Its field 
operations have been widened and it has been forced to retreat only in Tete province which borders on Rhodesia and Malawi. Even there, however, COREMO (a rival nationalist body) makes its presence felt by periodic probing operations. An estimated $3,500-7,000$ guerrillas have managed to engage and harass at least 50,000 Portuguese troops. In this context we can consider the boundary between Mozambique and Tanzania a potential catalyst for hostilities between Tanzania and Portugal.

The first Portuguese reaction to the outbreak of fighting in 1964 was to retaliate with full fury. They razed rebel-held villages, burned crops, and sought to isolate the rebels from the populace. Eventually, the Portuguese actually attempted to create a no-man's-land between the two territories, by clearing out villagers along the frontier (some 250,000 were moved), burning their dwellings and fields, and relocating them into 150 fortified villages. ${ }^{29}$ The result was to precipitate an exodus to Tanzania, mostly of the Makonde people who inhabit both sides of the Ruvuma (about 120,000 in Tanzania and 80,000 in Mozambique). In the first few weeks over 7,000 refugees crossed into Tanzania. ${ }^{30}$ By 1967 totals had risen to 19,000 in Tanzania and 1,800 in Zambia. ${ }^{31}$

It is small wonder that Portugal and Tanzania have been brought to the brink of hostilities over the mutual boundary. It seems as if Tanzania has not sought to avoid a clash. ${ }^{32}$ Accusations and counter-accusations have come from top government officials on both sides, ${ }^{33}$

The Tanzanian Government went even further. It allowed military training camps for guerrillas to be constructed in the southern frontier area. No less than nine separate training bases have been reported in southern Tanzania. The Portuguese claim they have evidence that instructors from the Chinese People's Republic are operating at four of them. ${ }^{34}$

This sort of policy led the Portuguese Foreign Minister Nogueira to suggest that the Portuguese might begin "legitimate retaliation" against countries like Tanzania, which have allowed "terrorist" bases to be established along their frontiers. "There is now a new doctrine of legitimate retaliation", he said cryptically. "We are taking a very good note of this new 
doctrine."35 A few incidents within Tanzanian territory in late 1966 and early 1967 appeared to lend substance to his warning. But the Portuguese troops have resorted to nothing so blatant as outright violation of clearly demarcated frontiers. 36

Tanzania has also asserted on numerous occasions that Portuguese military and civilian reconnaissance aircraft are violating Tanzanian airspace. Some of the planes apparently drop leaflets urging refugees in southern Tanzania to return home.37 Occasionally anti-aircraft guns fire on the violators, but no hits have been scored. ${ }^{38}$ If the war continues to go badly for the Portuguese, there is some likelihood that they may strike out in desperation to neutralize or destroy the privileged sanctuary beyond the Ruvuma. Dr. Mondlane has stated that FRELIMO takes a long-range view of the war, perhaps as long as ten years. Since Portugal is itself a poor country, there is reason to believe that it will not be able to sustain the present military effort (variously estimated at between 20 and $40 \%$ of the annual budget) for an extended period. 39 Needless to say, again the porosity of the Mozambique portion of the "southern border" of Africa contributes to the overall instability of the subsystems, and to the likelihood of clashes between units of each.

The Rhodesian liberation activities. The Rhodesian UDI found the nationalist liberation movements of RhodesiaZimbabwe African Peoples Union (ZAPU) and Zimbabwe African National Union (ZANU)-in serious and open conflict with one another.40 This situation has changed little in the intervening three years. Although open and violent internal resistance to the Smith regime has not been wanting, by and large African opposition lacks organization and co-ordination.41 It has essentially taken the form of spontaneous and sporadic outbursts with little long-range effect.

Likewise, the effectiveness of the ZANU and ZAPU forces operating outside Rhodesia has been marginal. They have managed to infiltrate a few hundred guerrillas into Rhodesia, but they have not been an insuperable challenge to the Rhodesian forces (reinforced by South African soldiers and police). The guerrilla campaigns began in August 1967 and were renewed 


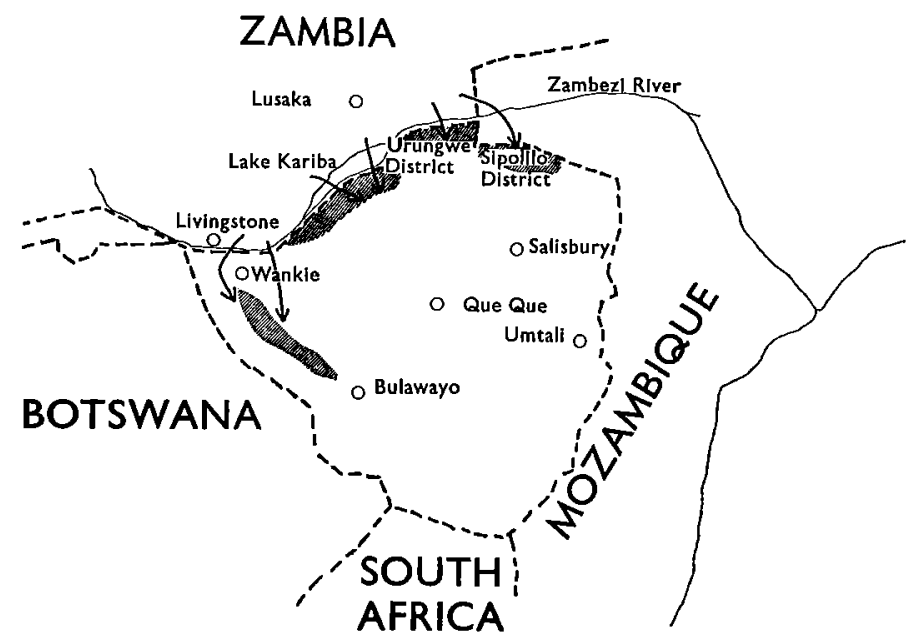

Fig. 4. Areas of reported fighting, Rhodesia, 1967-1968.

in March 1968. Apparently joint forces composed of ANC (South African) and ZAPU fighters crossed into Rhodesia from Zambia in a mass and then split into several units fighting in three separate areas. They were engaged by Rhodesian and South African forces, and most were killed, captured or fled into Botswana, where many were apprehended and imprisoned (see Figure 4). The 1968 infiltrations in March have not been markedly more successful and have largely followed the same pattern, although the nationalists appear to be better armed and trained than in the past. What is so noteworthy, however, is that the scale of the fighting is so small compared to the Portuguese territories, where thousands of rebels are in the field.

But why has the "southern border" along the Zambezi been so impenetrable, so far as guerrillas from the north are concerned? By far the most important reason has been the internecine struggle going on within and among various Rhodesian nationalist movements. This competition has made it virtually impossible to organize within Rhodesia, an indispensable ingredient for effective warfare. Contributing to this organizational difficulty, of course, has been the efficient information 
network built up by the Rhodesian police (working in both Rhodesia and Zambia), which has taken full advantage of ZANU-ZAPU competition. Another explanation can be found in the nature of the boundary itself. Rhodesia is safely surrounded on three sides by Botswana, South Africa, and Mozambique. Its most vulnerable flank is the 495 -mile border with Zambia. Thus, the Rhodesian security forces can be relatively concentrated. Moreover, running the length of this boundary is the Zambezi River (and in part, Lake Kariba), a formidable barrier in its own right. Even so, military analysts question whether the border-patrol system devised by Rhodesian security officials can prevent infiltration. ${ }^{42}$ Then here is the dilemma facing Zambia in dealing with nationalists from Rhodesia. Zambia is doubtless sympathetic to the aims of the Rhodesian nationalists. Both ZANU and ZAPU have offices in Lusaka (as well as in Dar es Salaam). Both use the Zambian radio to whip up support, although the broadcasts are jammed by Rhodesian authorities. But President Kaunda, fearful that the Smith regime may retaliate economically and unwilling to have Zambia turned into another Congo, had for some months denied the rebels permission to establish training camps in Zambian territory. However, a court case in 1967 brought to light the existence of a ZAPU training base in Zambia.43 Officially, Zambia denies harboring Rhodesian rebels. It serves primarily as a transmission belt and jumpingoff place for guerrillas coming from training in Tanzania and bound for Rhodesia.

This in itself is enough to give alarm to the Rhodesian authorities. The Minister for Law and Order has said that "If we relaxed our guard for a moment, gangs would again cross the Zambezi to continue their acts of murder and violence and sabotage".44 And more concrete measures in strengthening the Rhodesian security forces and increasing co-operation with South African forces is an obvious response. These steps will be treated more carefully in the following section. The overall effect of the incipient guerrilla war in Rhodesia, in terms of the "southern border", has been to orient Rhodesia southward and to force Zambia to search out alternative economic patterns and military support, while giving assistance, 
albeit cautious assistance, to the nationalists from Zimbabwe.

Conclusions. Patterns of rising border tensions along the various segments of the "southern border" discussed above have been similar. A group of political exiles, realizing that legitimate channels for dissent and for removing an unpopular government from power are closed to them, seeks support to overthrow the established regime. Naturally they gravitate to a neighboring country that sympathizes with their aims and that has already afforded asylum to refugees from the target territory. In the case of the Portuguese territories, the Congo and Tanzania seemed logical locations for rebel headquarters. Zambia had not as yet achieved independence. Malawi felt itself to be in too precarious a position and too dependent on Portuguese co-operation to risk upsetting its neighbor. Using Dar es Salaam and Léopoldville as organizational centers, the next step was to secure financial and military assistance from abroad. This was accomplished with the help and approval of the host governments and the OAU. The rebels also needed to organize military and political structures within the target territories, and to train a military cadre. Training facilities in both cases were supplied by host governments and the movements were on their way.

The wars erupted, either by pre-arranged co-ordination or as part of a follow-up to spontaneous rioting. In each instance, however, the security forces of the target government responded vigorously and repressively, forcing the rebels to adopt hit-and-run tactics. The emergent pattern was one of wars of attrition, with each skide building up its forces for a protracted guerrilla war. This placed a heavier burden on the host governments, since it strained relations with a neighboring state, demanded increased expenditures for the host government's armed forces (to defend its borders against possible retaliation and incursion and to neutralize the domestic conflict potential growing out of the presence of armed nationalists from another country on its soil), and drained precious resources by the influx of refugees. 45 .

The border during this long period displayed a dual and ostensibly paradoxical character. On the one hand, it appeared to become more rigid or firm. Troop concentrations in border 
areas served to formalize the boundary in a way in which it had not been formalized in the past. Portuguese and Rhodesian force levels rose sharply and were redeployed for defensive and counter-guerrilla activity. In Mozambique, Portugal actually attempted to cordon off an area by creating a noman's land between the two territories.

Refugees who fled the two colonies settled near the borders and guerrilla-training operations conducted by the rebel movements with the assistance of the host governments were not too far removed from the international divide. The border, in other words, took on the artificial appearance of two hostile forces separated by an often unclear line (especially in Angola). Such a situation generally means that clashes are to be expected, because the imprecision of the demarcated boundary augments a tendency to interpret the imprecision to one's own advantage.

But in another respect the border became a bridge between two separate lands. The boundaries are more porous than impenetrable, as the movement of people and material grows in volume. Despite efforts by the target government to prevent the flow, the physical task of doing this demands massive efforts that have been too difficult to mount. Into the Congo, Tanzania, and Zambia from Angola and Mozambique move four classes of people: (1) refugees fleeing from the fighting zones; (2) guerrillas using the host countries as sanctuaries and operational headquarters; (e) Portuguese troops in pursuit; and (4) in the case of the Congo, Katangese gendarmes and mercenaries, who on at least two occasions "invaded" or infiltrated into the Congo after being sheltered by the Portuguese. Moving into the Portuguese territories from independent black African states we find three kinds of people: (1) guerrillas infiltrating; (2) gendarmes and mercenaries fleeing the UN occupation of Katanga and later ANC retaliation; and (3) some refugees who have decided to return home after fighting has subsided. In addition, there is a diminished volume of normal, traditional, ethnic, and economic intercourse, except along the Benguela railway. With this sort of traffic, the boundary as an effective, policeable and defensible boundary is virtually non-existent. 
Table I. Military forces in southern Africa, rg66-rg68.

Unless otherwise noted, the data are from David Wood, The Armed Forces of African States, Adelphi Papers No. 27 (London: Institute of Strategic Studies, April, 1966).

\begin{tabular}{|c|c|c|c|c|c|c|c|}
\hline & $\begin{array}{l}\text { Regular } \\
\text { army }\end{array}$ & $\begin{array}{l}\text { Fully- } \\
\text { trained } \\
\text { reserves }\end{array}$ & $\begin{array}{l}\text { Air } \\
\text { force }\end{array}$ & Navy & Police & $\begin{array}{l}\text { Police } \\
\text { reserves }\end{array}$ & $\begin{array}{l}\text { Militia } \\
\text { or } \\
\text { guerrilla } \\
\text { forces }\end{array}$ \\
\hline Congo (Kinshasa) & 30,000 & n.i. & 2,000 & 一 & 21,000 & n.i. & n.i. \\
\hline Tanzania & 1,700 & n.i. & IOo & 一 & $I, 350$ & n.i. & n.i. \\
\hline Zambia & 3,000 & n.i. & 300 & - & 6,000 & n.i. & n.i. \\
\hline Rhodesia & $\begin{array}{l}3,400 \\
4,500\end{array}$ & $12,500^{a}$ & 9oo & & 6,400 & 28,500 & n.i. \\
\hline Port. Angola & $\begin{array}{l}50,000 \\
25,000^{a}\end{array}$ & n.i. & 3,000 & n.i. & 5,000 & n.i. & n.i. \\
\hline Port. Mozambique & $\begin{array}{l}3^{0,000} \\
5^{0,000^{a}}\end{array}$ & n.i. & n.i. & n.i. & 3,000 & n.i. & n.i. \\
\hline South Africa & $\begin{array}{l}16,200 \\
21,700^{b}\end{array}$ & 44,500 & 3,000 & 2,500 & 28,600 & 15,000 & 51,000 \\
\hline Malawi & 850 & n.i. & 一 & - & 3,000 & n.i. & n.i. \\
\hline Mozambique & 一 & $一$ & 一 & - & 一 & - & $8,500^{a}$ \\
\hline Angola & - & - & - & 一 & 一 & 一 & $\begin{array}{l}3,000- \\
8,000^{a}\end{array}$ \\
\hline Rhodesia & 一 & - & 一 & 一 & - & - & $\begin{array}{l}200^{a}- \\
500\end{array}$ \\
\hline
\end{tabular}

${ }^{a}$ Legassik, op. cit.

${ }^{b}$ McKay, op. cit.

Suppose a nationalist liberation movement should be successful and secure independence and the removal of a southern-directed government in a territory. The boundary formerly dividing independent from white-dominated Africa would most likely revert to its colonial-era status, i.e. a basically stable division between essentially distinct but not necessarily hostile political entities. The character of a border naturally depends upon the relationships between and the character of the regimes it separates. But the "southern border" itself, as a formalized wall separating two fundamentally hostile 
sociopolitical structures, would probably be relocated southward, and the process described in this section repeated anew.

Two other logical possibilities should be mentioned. The effective border could be moved northward or it could be solidified in its present location. It is conceivable that an existing African regime could be overthrown by forces more sympathetic to the southern regimes, and this new black government could opt to collaborate more closely with the southern states. Another possibility is the stabilization of the border. It has been suggested that a liberation movement may succeed in displacing a white regime, but given the economic conditions in its country, it may decide to continue close economic and perhaps other relationships with the south. In this way a friendly black regime in Mozambique, Angola, or Rhodesia could be more of a protective buffer from the revolutionary north than a friendly, but vulnerable and insecure white regime.

The balance of military power. It is quite clear from a comparative line-up of the military forces available to the principal participants on both sides of the border that the whitedominated south has a considerable advantage in regular force levels (see Table 1).

What is more, the imbalance is growing. To take just a single example, the case of South Africa is instructive. South Africa's defense estimates have been multiplied almost six times since 1960.46

$$
\begin{array}{rr}
1960-61 & 43,591,000 \\
196 \mathrm{f}-62 & 71,550,000 \\
1962-63 & 119,775,000 \\
1963-64 & 157,111,000 \\
1964-65 & 210,000,000 \\
1965-66 & 290,000,000 \\
1966-67 & 255,850,000
\end{array}
$$

The Permanent Force has risen from only 9,019 men in $1960-61$ to 21,700 in $1965-66$. Similar increases have been recorded in practically every branch of the security forces.

Moreover, available information indicates that South Africa is consciously trying to make its military forces self-sufficient 
by developing the economic infrastructure and the defense industries to maintain them, even under siege conditions. There have been rapid increases in budget provisions for the manufacture of munitions and weapons. 47 FN rifles, small planes, small ammunitions, radio and service equipment, and armoured cars are now being manufactured in the Republic.48 Oil-refining and steel production in the Republic have been expanded tremendously since 1960 . In contrast, the staggering economic problems related to development make such an augmentation of force levels almost impossible for states to the north.

In addition, the overall imbalance is compounded by the inexperience of northern soldiers and officers, their immense problems of communications, logistics, and supply, and their lack of combat aircraft and naval vessels. Against this, the southern forces boast modern equipment and weapons, plus a generally mobilizable reserve force (with the exception of the Portuguese territories) that would, perhaps, multiply their field forces four or five times.

In general, however, there is little point in detailing the military distribution of power along the "southern border". A classical military confrontation involving the armed forces of state $A$ against state $X$ is not likely, nor is a frontal clash between two sets of formal or informal allies, A-B-C against $\mathrm{X}-\mathrm{Y}-\mathrm{Z}$. There are a number of supplementary factors which naturally would affect if not determine the balance, among them (1) the problems of national integration, (2) the vulnerability of most national economies in the region, (3) the likelihood of external, non-African intervention, and (4) the overall lack of experience on both sides in dealing with guerrilla warfare. What good, for example, is the knowledge that state $A$ can field 30,000 well-armed and reasonably well-trained soldiers, 35 jet fighters, 15 helicopters, backed by 15,000 police, if, at the outbreak of hostilities, its social and economic fabric will collapse because of a lack of popular support for the government or the war? Since most of the states in the southern quadrant of Africa cannot be sure of all-out support for a military undertaking of a general magnitude, this is one factor which would require a'more complete country-by- 
country survey. Most discussions of military-force levels generally assume the essential stability of the political and economic systems necessary to sustain forces in the field. In the context of the African states we are dealing with, this assumption should not go unquestioned. Likewise, although it seems certain that non-African actors will participate in any general conflict between the two sides, no one is quite sure what the alignments will be and the extent of various external involvements. Thus, again, the unknowns leave too much to conjecture. Finally, and most important of all, experience since World War II shows that vast numbers of troops, concentrated fire-power, and sophisticated equipment are not alone adequate to defeat a well-organized and determined liberation movement, particularly if the latter uses guerrilla tactics. Traditional components of military power are not to be minimized entirely, for they serve as useful deterrents to potential rebels or to outside forces considering the prospects of intervention. Still, modern theories of guerrilla warfare clearly indicate that to the traditional factors of warfare must be added other factors-time, space, and political ideology-which are far less quantifiable and yet may well work to the advantage of insurgent elements.

Quite clearly the various nationalist liberation movements are aware of the possibilities open to them through protracted guerrilla wars. And some of the military thinkers and planners in the southern sphere are equally concerned about it. Not only have Portugal, Rhodesia, and South Africa concentrated on training and equipping their forces for counter-insurgency operations, but they have-gone even further. Commandant Neil Orpen, of South Africa, in his book' Total Defense, advocates that South Africa should begin to build up her irregulars and train them in commando resistance, a tactic that was used with great success by the Boers.49

Virtually all participants seem convinced that guerrilla warfare and behind-the-lines para-military activity will be crucial, particularly for the cause of black Africa. But we are unable to estimate with any certainty how Africans residing in the white-dominated states will respond to calls for support or to organizational efforts. We have little to go on regarding the 
ability of security forces to penetrate rebel movements in wartime or their ability to deal with wholesale sabotage. And how would each side react if the war began to go badly for it?

Within the southern grouping there seems to be evidence of a good deal more military co-operation between partners than in the north. Despite the entreaties of men like Kwame Nkru. mah that Africa or the OAU should establish a unified military force, nothing of this sort has emerged. There is some measure of OAU support for various liberation movements operating in the south, but even so it has not expanded co-ordination and co-operation between groups or among states. The ZAPU-ANC joint venture into Rhodesia in the summer of ${ }^{26} 7$ was unusual in this respect, but it merely served to give South Africa a perfect rationale for open collaboration with Rhodesian security forces. Aside from bilateral assistance by northern host governments for rebel nationalists from the south, little material inter-state co-operation has taken place.

Contrast this with the picture in the south. Speaking in January 1968, a South African official said that it was time South Africans realized that, if the soldiers which Portugal had in Angola and Mozambique were to be withdrawn, South Africa could become involved in a terrorist war within weeks. He went on to say that the Portuguese territories and Rhodesia have become South Africa's first line of defense.50 This is but the most recent expression of a philosophy that has been recognized for some time. After overcoming initial misgivings that Portugal might be an unreliable ally, South African officials have sought to put together a military alliance, first with Portugal and the old Central African Federation, and now involving the Smith Government of Rhodesia. Claims of a so-called "unholy alliance" have been in the news since about 1961. South Africa's Foreign Minister has even stated at the United Nations that a "mutual security arrangement" exists among the white regimes of southern Africa and the black governments of Botswana, Lesotho, and Malawi.51

After the eruption of the war in Angola, the South African Minister of Defense visited Lisbon, and although no formal treaty was announced, increased collaboration soon became evident and speculation about secret arrangements grew.52 
There was a time when the co-operation extended into black Africa itself. Up until 1969 , both the Central African Federation and the Katangese Government of Moise Tshombe were brought into some of the arrangements. ${ }^{53}$ The Katangese secessionists were materially assisted by the Portuguese and the South Africans, in return for which the Portuguese were assisted in surveillance of the Katanga-Angola frontier, the UPA offices in Elisabethwille were closed and its leaders claim that its officials were turned over to the Portuguese authorities.

The most recent and obvious manifestations of co-operation surfaced during the nationalist infiltrations into Rhodesia in August 1967 and March 1968. According to Colin Legum, this was the first open sign of the under-cover defense arrangements between the Smith Government and South Africa which had been concluded between their military chiefs.54 Prime Minister Vorster officially confirmed reports that South African "police" were assisting the Rhodesian security forces. Actually, however, the assistance was far more significant than simply "police" units. South African military forces had been training Rhodesian anti-guerrilla patrols in the Zambezi Valley, and these units, which included helicopters, are believed to have been pressed into service in August. ${ }^{55}$ There were also reports that special police were flown in to interrogate prisoners, that an additional "police" unit joined the Rhodesian forces in the Wankie area, and that an armored car unit of "police" arrived in September. ZAPU estimated that approximately 5oo South African men were in the field with the Rhodesian forces. There is also some indication that South Africa attempted to disguise the extent of their involvement by painting their helicopters in Rhodesian colors and by equipping some of their troops with police uniforms. 56

It is not easy to appraise the nature or prospects for a military confrontation in southern Africa. Many are convinced that the struggle will be a long and bloody one. Others, such as the Prime Minister of Lesotho and the Malawian President, are convinced the southern forces would win easily and quickly. 57 The problem is that, no matter how precise our data on force levels and trends in military preparedness, there are far too many variables to manipulate, some of which have no data 
available at all. Thus the "southern border", although it divides two hostile armed camps, will not necessarily be altered in the near future. We cannot say with any assurance when, where, and in what ways it will first be revised.

\section{Economic and transport relationships along the border}

The economic realities of the states along the "border" set the tone for the political character of it. That is to say, states that are economically dependent on the co-operation of other states are less likely to strike an independent course in foreign policy. Granted this is a generalization subject to a good many reservations, and in the context of southern Africa there are states that have managed to show a good deal of flexibility and independence in foreign affairs in spite of their economic weaknesses. This maneuverability may in turn help to extricate them further from a disadvantageous economic position. But unless one weighs in the balance the inordinate economic influence of South Africa and the prime geographical location of the Portuguese territories, it would be difficult to explain their magnetism to states such as Malawi, Botswana, and Lesotho, states which certainly, all things being economically equal, would share few affinities with the white-dominated south.58

The most imposing structural characteristic of southern African affairs is the unchallenged economic domination of the Republic of South Africa.59 This more than any single fact has led to the economic, military, and diplomatic spider web that is being constructed in the region. It is not our task to provide a detailed compilation of the data on the subject. In general, it has been well researched and information is plentiful. But it would be useful to summarize some of the data, especially as they shed light on economic interrelationships in the region.

First, South Africa has an economic stranglehold on the three former High Commission Territories. Botswana, Lesotho, and Swaziland, which, because of their geographical location, 
their lack of exploitable resources, and their history of sending labor to the Republic, are virtually economic prisoners of South Africa. ${ }^{\circ 0}$ The resulting foreign policy reflects this insecurity and dependence. Regardless of the policies of the government in Pretoria, indeed even if it became a black government, Botswana, Lesotho, and Swaziland would still be dependent on the goodwill and favor of South Africa's leaders. It is in this regard that Bowman calls the three territories and the Republic a "mini-Southern African system under any foreseeable circumstances". ${ }^{01}$

Cohesion among the southern states and political influence for certain of them also grows out of the transport networks that have been developed. For example, the railway network in the region has tended for years to orient Zambian, Malawian, and Katangese shipments through the white-dominated territories, thereby ensuring a modicum of good relations between countries sharing the same transport and port facilities. What we are interested in here is to what extent these patterns have been altered since UDI and how this effects relations across the "border".

The most important economic link between the Republic of South Africa and Mozambique has been codified in the Portuguese-South African convention of 1909 (as amended). Under the terms of this convention, the Witwatersrand Native Labour Association (WNLA) may recruit up to 100,000 Africans annually in Mozambique (south of $22^{\circ} \mathrm{S}$.) for work in the mines. In return, the South African Government guarantees, inter alia, that $47.5 \%$ of the shipping traffic of a defined area of the Transvaal will pass through the port of Lourenço Marques. Actually, this minimum requirement is regularly exceeded because of congestion in the Republic's rail system and because this port is closer to the Transvaal than any South African port.

The Republic has extended its influence into Mozambique in other ways. A natural-gas pipeline is being laid between Moamba, 6o miles north of Lourenço Marques, and the Transvaal. It is largely being financed in South Africa. An even more impressive co-operative project is the proposed hydro-electric scheme at Cabora Bassa on the Zambezi. Again 
a good part of the estimated costs of $\$ 365$ million is to come from South Africa. When completed, this will supply about $8 \%$ of South Africa's projected electricity requirements, as well as being integrated into the power grids of Malawi, Rhodesia, and, the Portuguese hope, Zambia.

Mozambique also stands in a preferred position vis-à-vis Malawian and Rhodesian transport. Until 1966, when the Limpopo line to Lourenço Marques was completed, the port of Beira handled the vast bulk of traffic for Malawi, Rhodesia, and Zambia. It still is the prime outlet for Malawi and Rhodesia. In 1966 and 1967 Beira lost traffic as a result of the sanctions imposed on Rhodesia. The crude-oil pipeline from Beira to Umtali in Rhodesia was closed early in 1966, so Portugal lost this source of transit charges. Rail traffic from Rhodesia also declined when Zambia sought to open alternative routes not passing through Rhodesia.62 Rhodesia in fact has re-oriented its supply routes to South Africa by road and by rail to Mozambique from Lourenço Marques.

But Mozambique losses due to sanctions are being offset to some degree by a closer economic association with Malawi. As soon as a 120-mile section of track is complete, the port of Nacala will have an international rail connection with Malawi. At least part of this will be financed in South Africa. There are further plans for extending the Nacala line to Lake Nyasa and for building a new port at the mouth of the Zambesi. To some extent Malawi's increased traffic with Mozambique grows out of Rhodesian efforts to evade sanctions. It is a co-operative President Banda who has permitted the use of Malawian facilities (for a consideration) for transshipment of Rhodesian products. ${ }^{63}$

On the western side of the continent Angola stands in a similarly profitable position. Although Angola has had no important transport links with South Africa, the Benguela railway has been a lucrative source of funds and political leverage for the Portuguese authorities. Before UDI a large majority of the imports and exports of Katanga passed along the Benguela railway and through its port of Lobito. But recently the Congolese Government has sought to diminish its dependence on this route. In December 1966 the Congo curtailed 
shipments of refined copper through Lobito and rerouted them to its own route nationale. Because of the high expenses of the route nationale, however, it continued to rely upon the Benguela railway to export manganese ore. But the overall effects were important. At present only about $45 \%$ of Katangese exports move out via Benguela.

But where Katangese dependence has declined, Zambia has taken up the slack. ${ }^{64}$ Zambia traditionally had two rail links with the outside world; one via Rhodesia to Beira or Lourenço Marques, about 1450 miles long, and the other via the Congo and Angola to Lobito, some 1474 miles away. Before UDI virtually all of Zambia's copper was exported through Rhodesia, and practically all of its petroleum came by way of Rhodesia. At present none of Zambia's oil comes via Rhodesia and about $60 \%$ of the copper exports have found alternative, albeit more expensive, routes. Tanganyika Concessions Limited, an essentially British-owned holding company, owns go\% of the Benguela Railway and about $14 \%$ of Union Minière. So they, along with the Portuguese Government, are anxious to see expanded use of this route and its continued availability. Thus, when guerrillas cut the line temporarily in mid-1967, Tanganyika Concessions put pressure on the Portuguese Government to demand that Zambia clamp down on Angolan nationalists operating out of Zambia. Both the Zambian and Congolese Governments had a chance to see what the consequences would be if Portugal carried out its threats to close the line. The Zambians responded by refusing to renew UNITA leader Jonas Savimbi's residence permit. Curiously, in an effort to extricate itself from dependence on one whitedominated territory (Rhodesia), Zambia has had to rely on another (Angola).

The Rhodesian UDI was also the event that turned Zambia northward in other aspects of its economy. A pipeline linking Ndola with Dar es Salaam has been completed on schedule in September 1968, and the Great North Road to Dar es Salaam is to be improved once the pipeline is in operation. ${ }^{65}$ But even with the re-routing of copper and oil, Zambia will still be dependent on Rhodesia for the transport of about three-quarters of its imports and a high percentage of its ex- 
ports. An alternative and reliable rail link seems to be the only long-range solution. This appears to be some time off. ${ }^{\theta 6}$

The railway system run jointly with Rhodesia is still nominally a unitary organization, but only because Rhodesian and Zambian officials have not been able to reach agreement on an equitable distribution of its assets. ${ }^{97}$ Meanwhile, Zambia is creating its own rail system and has purchased new rolling stock to replace that which was confiscated by Rhodesia. In July 1967 Zambian Airways was set up out of the Zambian portion of the now-defunct, jointly owned, Central African Airways. Zambia now controls its own airspace and telecommunications are no longer wholly dependent on the link with Salisbury. A new trucking firm, Zambia-Tanzania Road Services, has been set up by the two governments largely to haul oil to Zambia until the pipeline is completed.

Zambia has also made efforts to increase trade and transport links (as well as political ones) with the other East African states. Zambia has formally applied for association with the signatories of the East African Treaty of Co-operation, and it has sent vigorous trade delegations to each of the East African countries. In general, Zambia has not been especially successful in finding new markets and sources of supplies to the north. But it has been surprisingly successful in cutting its direct trade with Rhodesia. In 1965 Zambian imports from Rhodesia topped $£_{35}$ million (over $33 \%$ of its total imports). In 1966 this was reduced by $£ \_1$ million to less than $20 \%$ of its total imports. In 1967 a further decline was expected, since only $£ 19.1$ million worth of goods were imported in the first nine months, slightly over $11 \%$ of the total. ${ }^{68}$ Most of the remaining imports are of coal and Kariba power for the copper smelters. Efforts are being made to find replacements for these two commodities, too. Still the alteration in import patterns is significant. In less than two years since UDI Zambia has been able to reduce imports from Rhodesia by $5^{0 \%}{ }^{.99}$ Even so, Zambia remains Rhodesia's most important single market and about $75 \%$. by weight of all Zambia's imports still pass through Rhodesia. Exports to Rhodesia from Zambia have been even more drastically curtailed-from $£ 5,470,225$ (1965) to a 1967 figure of approximately one-quarter of that. 
But a curious trade pattern is developing, one that was not fully expected at UDI. Ironically, although it appears to belie Zambia's efforts to cut trade with "racist Rhodesia", the Republic of South Africa is reaping the profits of Zambia's disengagement from Rhodesia. Not only has Rhodesian trade with South Africa increased but by April 1966 South Africa had filled Rhodesia's place as Zambia's principal supplier. Thus, Zambia has not been fully able to free itself from the south and especially Rhodesian economic influence. Though projects to supplant existing linkages are in advanced stages, this pattern will prevail for several more years.

Rhodesia has moved even further under South Africa's economic influence.70 Prior to UDI, Rhodesia traded heavily with South Africa, but could not be regarded as economically dependent on it. This is no longer the case. ${ }^{71}$ South Africa has become Rhodesia's principal supplier of petroleum products, and it has permitted unlimited exchange of the Rhodesian pound for the South African rand. These two policies have kept the Rhodesian economy afloat. In 1965, some $8 \%$ of Rhodesian imports came from South Africa. By 1966 this was estimated to be about $13 \%$, and by 1967 estimates have ranged as high as $33 \% .^{72}$

South Africa and Rhodesia continue to use migratory labor as a powerful political lever. It is estimated that the following numbers of laborers have emigrated to South Africa and Rhodesia from black Africa. ${ }^{73}$

\begin{tabular}{lrr}
\hline From & To South Africa & To Rhodesia \\
\hline South West Africa & 6,000 & \\
Lesotho & 280,000 & \\
Swaziland & 66,000 & \\
Botswana & 85,000 & \\
Rhodesia & 75,000 & 200,000 \\
Malawi & 73,000 & 118,000 \\
Mozambique & 220,000 & 70,000 \\
Zambia & 16,200 & \\
Others & 15,000 & \\
\hline
\end{tabular}


It is Rhodesia's threat to repatriate this labor force that can be used to put pressure on its neighbors.

Conclusion. In general, we have an intricate set of economic relationships across the "southern border". Despite the apparent confusion, certain key relationships can be easily seen.

Among these configurations are Angola's anomolous economic independence of the south and its more important dealings with Zambia and the Congo. But Portugal's intention to remain in Africa has driven it to strengthen its military and political links with the white south. Angola is one of the examples in the region (Zambia is another) where political and ideological considerations outweigh economic ones. In Angola's case, however, potentially fruitful economic relationships with the Republic of South Africa may be a long-term contributory factor.

We can also see that Zambia's efforts to escape the southern African economic orbit have been fairly successful, although not yet complete. If plans progress according to schedule and desire, Zambia's remaining ties with Rhodesia and South Africa will be severed, and those with Angola and Malawi will become mere vestiges of what were really intended to be only short-term substitute arrangements. Likewise, the Congo appears to be intent on discontinuing its use of the Benguela railway. On the other hand, Rhodesia, Malawi, Botswana, Lesotho, and Swaziland are inextricably linked with the southern economic system and increasingly so. In these ways, then, the economic dealings across the border have been and still are far more significant and difficult to alter than the diplomatic and political relationships. Even so, changes have been made and the border does show tendencies to become a more rigid dividing line between two separate economic systems as well as between two hostile social systems.

\section{Conclusions}

Inter-state relationships in southern Africa have been treated differently in two recent papers. ${ }^{74}$ Zartman regards continental Africa as possessing the necessary components of a subordinate state system. First, as a geographic region it serves both 
as a territorial base and as an identification area. Second, in the OAU it has an international organization. Third, it has intra-relatedness or autonomy, i.e. intra-system actions and responses predominate over external influences.75 This does not mean that the system is independent or free of outside influences and relations. In this framework, then, Zartman deals with white-dominated southern Africa as a "fringe area", an unfulfilled segment of the geographic entity Africa, the existence of which serves to keep the "inner limits of the system" together.

Bowman, on the other hand, posits that the states of southern Africa constitute a subordinate state system in their own right. In other words, implicitly he would divide Africa (for analytical purposes) into at least two subordinate state systems. ${ }^{76}$ The evidence assembled in this paper suggests that in the past few years, particularly since UDI, the white-dominated states of southern Africa and their black-governed economic client states have become more organizationally cohesive and intra-related, and in some degree increasingly autonomous. The states to the north have not exhibited such a marked trend.

There is another possible approach to the issue of interstate relations in southern Africa. Perhaps the word "system", even if modified as "subordinate system", may be too strong. What we might be observing is a simple "sphere of influence" arrangement based on the inordinate economic strength and geographic proximity of the Republic of South Africa. In many respects relationships between actors within the white-dominated region, especially those of the black-governed states, reflect the traditional behaviour of states that are economically dependent. They perceive constraints upon their political independence and their foreign policies reflect this. Economic relationships within the region are growing. And non-economic co-operation seems to be more of a reality in the south than in the north. But for this hypothesis to be defensible we would have to deal frontally with the cases of Zambia and Angola. The former has been economically within the white-dominated sphere but managed, for political and ideological reasons, to extricate itself, if not completely, at least convincingly, 
given the short time involved. Angola is not economically enveloped in the vortex of South African economic power. Yet Portugal has, by choice and for obvious reasons, opted to be part of the southern system. Although the sphere-of-influence hypothesis may explain certain aspects of behaviour, it may overlook others.

Could we, perhaps, look at the division across Africa as a kind of ideological curtain? The countries to the south are dedicated to the principle of white or European rule, and those to the north to the destruction of this philosophy in Africa. This is a particularly popular framework for statesmen and journalists. But it leaves vague the status of Malawi, Botswana, and Lesotho, nominally independent states but not particularly interested in perpetuating white rule. Simple expediency might dictate that they co-operate for defensive reasons with the white states that surround them; otherwise, as blackgoverned states they would be the first to suffer in a white offensive. This approach, however, is far too simplistic to be sustained. Yet, undeniably, the component of ideological and racial cohesion in the south as well as in the north must not be ignored.

Whatever analytic technique is employed to deal with the relationships between groups of states in the region, it is still necessary to locate the "southern border". It seems clear that the "border" must be regarded as extremely plastic. In the course of the past seven or eight years several major locational changes have been recorded. This reinforces the difficulties of dealing with systems in a formalistic sense. As Zartman states:

The recognition of overlapping systems in interpreting foreign policy alternatives and possibilities for states with dual membership is both a more helpful and a more realistic way of looking at foreign policies than is the attempt to force such states exclusively into one area or the other."

For the black-governed states along the "border" or geographically within the white orbit, there is a range of alternatives and possibilities in foreign policy that could make the intra-group relationships extremely fluid.

But historical experience indicates that the range of alterna- 
tives is only drawn upon when a significant change of government occurs. In only one instance have we had an apparent reversal of policy by a state in which there was no change of government. This was the case of Malawi's drift into the South African orbit, although this has been offset somewhat by the continued efforts by some states (Zambia and Tanzania among them) to open doors to Malawi to the north.

There was a time when the Congo was regarded as the battleground between the two systems. Particularly during the period of Katangese secession, the "border" might actually have been drawn along the line of Central Congolese-Katangese hostilities. When Katanga was brought within the nominal control of the Central Government, the "border" was moved southward. Then again from June Ig64, when Tshombe took control of the Central Government, until his removal in October 1965 , there were some who once more either regarded the Congo as a battleground or actually included it in the southern orbit. ${ }^{8}$ Once General Mobutu had established his credentials as an African nationalist, the Congo once again became part of the northern system and its border with Angola represented a component of the "southern border".

With the break-up of the Federation of Rhodesia and Nyasaland, further complications appeared. At first analysts readily drew the line at the Zambezi, with Zambia and Malawi to the north and Rhodesia to the south.79 After a while, however, this clear-cut division became more difficult to sustain. Obviously, after UDI Zambia attempted to cut its ties with the south and to join the black north. But President Banda, of Malawi, hedged his position, finally opting for the south because of his perception of Malawi's economic vulnerability. At least this is the impression advanced by Bowman and others. ${ }^{80}$ But given a change of government in Malawi, this situation could be altered overnight, as it was with Zambia's response to UDI.

It has been shown elsewhere that, by and large, the borders between black African states are historically and ethnically irrelevant, but that with a few exceptions they do not contain the seeds of major conflict between African states. ${ }^{81}$ The data presented herein lead to the conclusion that, with respect to 
the borders that make up the division between white and black Africa, it is not the boundaries per se that possess conflict potential but rather the policies pursued by the governments on either side. Thus, the border is an uneasy one, not because of the nature of demarcation and/or delimitation of the boundaries, but because there are far more serious issues at stake. The "southern border" is a critical and unstable one, because of neighboring governments. These governments are not struggling for a few hundred square miles of territory here or there, but for principles and for whole states whose futures are bound up in those principles.

Governments to the north of the border have used all the techniques at their disposal, short of conventional warfare, in their attempts to dislodge white governments from the south. Formal diplomatic, paradiplomatic, and economic techniques to isolate and weaken, propaganda to discredit and mobilize, conspiracy and subversion as well as encouragement to help political exiles from the south, and aid and sanctuary to assist terrorists and guerrilla forces seeking to destroy minority regimes are being employed in varying combinations by the Congo, Tanzania, and Zambia. Given the adverse balance of military forces in favor of the white south, there is little wonder that rational policy-makers in the north will eschew a frontal conventional war for some time, if at all possible, unless they are inadvertently drawn into a war by the political exiles and organizers they are harboring. 82 Thus, host governments are placed in an awkward position. The southern liberation movements are at once the most promising instruments for carrying out policy on behalf of the states to the north (in their desire to remove white regimes) and the most dangerous for precipitating a full-scale confrontation which they would be unable to win, barring massive outside intervention or else a widespread uprising of Africans in the southern territories.

So the picture is one of a fluid border that tends to shift location with revolutionary shifts of government-by and large (except for the case of Katanga) by whole states at a time. The "southern border" has been effectively a residual border, reflecting the creation of two admittedly fluid sets of relation- 
ships dividing the continent. Should these groupings become crystallized, the border would assume a firm character of its own, tending to reinforce rather than reflect patterns of relationships. There are signs that this is increasingly the case. For how long and in what ways it is defensible, it is hard to say. The evidence presented herein offers no conclusive answers. But merely to observe and document this fluidity and the insecurity of the two groupings suggests further fields for study. 


\section{Hadži-Vasileva}

\section{Inter-African Economic Co-operation}

To resolve, to some extent at least, the problem of resources, which would mitigate economic difficulties and create more favourable conditions for the promotion of their economic development, the African countries have embarked on the road of closer economic co-operation. Trade relations between the African countries are still extremely undeveloped. The reason for this should be sought primarily in the prevailing international division of labour, and the concurrent specialization of the exports of African countries, which consist mostly of raw materials. In fact, the characteristic trait in the pattern of these exports is the absence of industrial products. The fact that many African countries belong to different closed currency and preferential zones largely accounts for this state of affairs.

According to the data published by the Nigerian paper $A f$ rican Pilot, inter-African trade in 1965 accounted for a mere 3.5 per cent of Africa's overall foreign trade. The bulk of Africa's trade is still primarily oriented towards the markets of the industrially developed countries, which absorb nine-tenths of the total trade of the continent.

In their endeavours to create an independent economy, the African countries attach great importance to mutual economic co-operation and devote particular attention to the establishment of a common African market. After a number of different proposals on the formation of a common African market -which encountered serious obstacles, because of the insufficiently diversified economies of the African countries-greater attention was given to the joint examination of different plans of development and their various disparities, as the best 
way of averting rivalry in the acquisition of foreign aid, as well as investment in identical projects.

Considerable efforts are being made towards the achievement of monetary unity (there are 26 different currencies in Africa), i.e. the creation of a kind of monetary union which would make it possible to attain unity. The African monetary union should be formed along such lines as would not deprive the African states of those markets in which they enjoy a privileged position, i.e. where they can market their goods under the optimal conditions and mobilize the necessary capital. The world-renowned expert on monetary matters, Professor Triffine, of Yale University, who is engaged in studying the problems involved in the establishment of the African union, has proposed (in one of his reports) the formation of an African monetary council, an institutional mechanism within whose framework future development could be put into effect. But, this is not a complete solution, for without a common fund whose reserves would be sufficient for a general "clearing" of all African payments, it would be hard to expect any tangible results in this sphere.

The United Nations Economic Commission for Africa (at its session in Addis Ababa in 1964) endorsed in principle the project of a common African market. However, in view of the fact that the Commission expressed the opinion that all the necessary conditions for the establishment of a common African market had not yet matured (these conditions refer to political willingness, economic need and qualified personnel), its implementation was postponed. Bearing in mind the difficulties. involved in the creation of a common market, the UN Economic Commission for Africa turned to the targets that can be more rapidly reached but that ultimately lead to the creation of a common market which would include all the African countries.

Outside the UN Economic Commission for Africa, there are also numerous initiatives for the establishment of various groups designed to facilitate mutual economic co-operation. In West Africa, plans for the creation of new customs unions are now being considered. In this area there are several customs unions, dating back to earlier periods, which exclusively 
encompass the countries of the French-speaking area (the Western Customs Union and the Equatorial Customs Union).

The economic integration of the African states would have a number of advantages. In the sphere of foreign trade, the economic union would help to eliminate the causes of competition and establish more profitable mutual trade. It would lower the costs of industrial products and improve the conditions of their sale, both on the internal and foreign markets. Economic integration is of particular significance for the countries with a small population which cannot industrialize without the support of a broader market. The economic union would have an increasingly broader base in regard to raw materials and power. Conditions in the field of hydro-electric power are most favourable (on the Volta River, a complete system of dams could be built; the Niger River joins a number of states together (Niger, Cameroon, Gabon, Chad, the Congo, etc)).

The developing industry of the African countries would not be in a position to sustain the competition of the developed countries, unless previously protected by a common customs tariff. Hence, the striving for a customs union, as one of the initial steps towards economic integration. The creation of a common infrastructure would, beyond any doubt, facilitate and accelerate the development of the poor and small African countries. Co-ordination of developmental programmes could lead to the specialization of agricultural products, according to the conditions of each individual country.

Considerations of principle and discussions on the conceptions and ways of achieving economic unity have shown that this unity would have a number of advantages over fragmented and divided action. However, in practice things often take their own course, contrary to that envisaged in considerations of principle and intentions of unity. Many obstacles stand in the way of all-African economic integration, not the least significant of which is foreign interference, aimed at breaking up African unity in all its aspects, and primarily in the economic area. However, there are also a number of objective difficulties which obstruct the process of a more rapid economic integration. These are chiefly the following. 
Economic integration, as it is envisaged, implies the integration of poor countries. Projects are then undertaken which most often exceed the potentials of those who wish to realize them.

The economies of the African countries have been developed as complementary to the economies of the metropolitan countries, which means that they are incomplete economies. And several incomplete, non-complementary economies can hardly, at the outset at least, yield any major results, for successful economic integration requires at least a minimum of specialized production.

Another impediment to economic integration (no less so than to political integration) is the language barrier (the French-speaking and English-speaking areas, as well as the numerous different African languages).

The unsettled border relations between many countries also constitute a grave obstacle, of which the most serious aspect is no doubt the differences in political systems and orientations of social development. When unity on matters of social and political development is lacking, it is not always easy to find a common language in regard to economic co-operation, yet the primary factor which stands in the way of economic integration is the low level of development of the productive forces, for integration implies specialization, which is an expression of developed productive forces. Hence, the prospect of broader economic integration is distant, though closer than political integration, i.e. it represents the first step towards political integration. 
Anat. A. Gromyko

\section{Colonialism and Territorial Conflicts in Africa: Some Comments}

In order to understand any problem, one has to explore its background, especially if the problem has its roots in history. Such is the problem I propose to discuss now. The territorial problems of Africa have been brought into being by history, in which different forces are known to have been at work. In this connection I would say that Africa's territorial problems have a father, whose name is colonialism. So it seems to me that we should bear this historical fact in mind.

Let me emphasize that one of the basic reasons for current territorial conflicts in Africa is the fact that state frontiers are at variance with the boundaries of national settlement. This is a grim heritage of colonialism, a heritage which is known to give rise to tension in relations among the independent African states.

Newly independent African states have emerged as a result of the disintegration of the colonial system of imperialism, within the borders drawn by European powers on the map of Africa, after they divided the continent. It is well known that Africa was finally divided by the imperialist powers in the 1880's. This division took place in the course of a bitter struggle among Britain, France, Germany, Portugal, Belgium, Spain and Italy. African peoples resisted the invaders rather stubbornly, but their forces were no match for those of the Europeans.

The colonial division of Africa by the western European powers reflected their balance of power in the last quarter of the 19th century. This balance of power was secured in corresponding treaties and conventions concluded by them. As a 
result of this struggle for raw-material resources, markets and fields of investment, a struggle that minced Africa, today 44 per cent of the frontiers of the continent's states and territories run along parallels and meridians, 30 per cent along direct lines, arcs or curves, and only 26 per cent along natural geographical boundaries, such as rivers, lakes, mountains and valleys.

But, of course, not only did colonialism mince Africa, but in the process tried to prevent the formation of large ethnic communities in the colonies. It was not by chance that the ideologue of British imperialism, Field-Marshal Smuts, in an attempt to aggrandize the idea of indirect government in colonies, was at pains to emphasize the need to preserve various types of tribal institutions for colonialism to lean on in Africa. Lecturing to colonial officers at Oxford University, Smuts put it bluntly when he said that the collapse of the tribal system must be prevented by every possible means. He tried to scare colonialists by saying that, should the tribal system disappear, Africa would fall into chaos. All this is to be found in his book Africa and Some World Problems (Oxford, 1930).

It stands to reason that colonialists cannot be held solely responsible for the presence in Africa of motley and isolated ethnic groups. They existed well before the advent of colonialism. But the fact remains than colonialists deliberately used tribalism to cause damage to African peoples. Profiteering from tribalism was made government policy.

Late in the $19^{\text {th }}$ century such views were in ample supply, some of them not only being proclaimed but also put into practice. This largely explains why even by the mid-fifties of this century a major part of Africa remained at a low stage of social and economic development. In general, it may be said that the slave trade, which began in Africa in the $15^{\text {th }}$ century, the subsequent division of the continent by the imperialists, the preservation of old social institutions and the establishment of colonial regimes there have hampered the development of African society and its economic integration for many years.

Thus, the father of the child-the problem before us-is well known. It is colonialism. However, no matter how right we 
may be in identifying this historical fact, it nevertheless fails to solve the territorial problems of Africa today. As newly independent states emerged in Africa, the problem of terri. torial problems also came up. For some time it was fashionable among African states to speedily eliminate or revise the old frontiers.

At present, I believe, it may be said without fear of contradiction that this trend is on the wane, being gradually replaced by the tendency to preserve the existing frontiers. It is heartening to see that now the desire of African states to settle their territorial disputes through the Organisation of African Unity has grown stronger.

Soviet Africanists believe that this positive trend is favourable for Africa. Without underrating in the least the specific nature of African territorial problems, we believe that, no matter what the occasions or causes of territorial and border disputes may be, they should be settled peacefully. Faced with gigantic social and economic problems, Africa would undoubtedly benefit, if the use of force were finally renounced in international affairs in relations between the African countries themselves. Thus, it may be said that, although the territorial problems of Africa have been brought into being by colonialism and that their solutions are far from being easy; it is nevertheless clear that all these disputes must be settled through negotiations.

The concept of Soviet Africanists that territorial disputes in Africa must be settled by peaceful means to be chosen by the parties concerned does not at all apply to the relations of African peoples with colonial powers, such as Portugal, for instance. We think that, if the colonialists balk at vacating the territory they grabbed in the past and at granting independence to the oppressed peoples, freedom-fighters in the countries concerned have a full moral and legal right to expel by force of arms the colonialists from their territory, such as Angola and Mozambique; "Portuguese" Guinea and South West Africa. The return of territories to their legitimate owners, the native inhabitants, is not the only acceptable way of settling such problems but the only way possible when colonialists do not wish to withdraw from foreign territories. 


\section{Carl Gösta Widstrand}

\section{Some African Boundary Problems: A Discussion}

One of the aims of the discussion that followed the papers presented in this volume was that only border disputes should be discussed and that anything relating to broader policy questions-political, economical or sociological-should be omitted. This, however, proved to be impossible. It is difficult to discuss boundary problems without going extensively into all the other related spheres, to discuss border regimes without going into law, to discuss constitutionalism and the very broad area of international relations without going into politics, to discuss ethnic relations without going into sociology, etc.

Mainly because of lack of time, the discussion was concentrated on the following topics: legal problems, categories of boundary conflicts, the concept of nationalism, the constellation of economic interests around borders, South Africa and the "southern border", some future boundary problems and some research projects or subjects of high priority.

\section{Legal problems}

What seems to emerge on the international legal plane is that there are relatively few binding rules of international law that one can confidently cite or apply in a given instance. Thus, it is reasonable to say that every boundary problem is unique and can only be solved to a certain extent by analogy. Other problems in the legal field concern technical issues, such as finding out where the borders really are. There are the difficulties of physical demarcation, both as a legal exercise and 
as a survey, and there are the problems of physically preserving the demarcated boundary on the ground.

Another question which was taken up several times was the difference between borders and their related problems in Europe and in Africa. Boundaries in Africa are in part irrelevant for the performance of governmental functions, such as movement control. Most frontiers do not function like the Berlin Wall and many of the functions that we are familiar with are not in operation. Nevertheless, if we discuss boundaries in Africa, we must keep, in mind a "multifunctional concept" of the boundary. The absence of control of movement of people does not indicate that the boundary still functions in other respects. People may move freely, but they are treated differently on each side of the border. We should have a wider concept of control and ask: How well do the national governments on each side of the boundary control their local territories? How well developed is local administration, local taxation systems, etc.?

\section{Gategories of boundary conflicts}

Several authors have categorized boundary conflicts into (a) boundary disputes, $(b)$ territorial claims or irredentism and (c) minority problems and secessionist tendencies. To a certain extent such categories are helpful and logical, as long as we do not forget that they are unreal. We can understand boundary disputes and territorial disputes as being different in a commonsense way: a boundary dispute is about a line, a territorial dispute about a territory, minority problems are about people. But these problems or categories may all be transformed into each other. The most constructive view would be to regard the categories mentioned as working categories, for use when we want to investigate one specific aspect of the problem.

\section{The concept of "state" and "nationality"}

The discussion on this point opened with a remark in Professor Allot's paper, in which he distinguished between a po- 
sitive and a negative definition of nationality-one admitting certain individuals and giving them the status of nationality and the other more concentrated on excluding other individuals. There is no empirical evidence that there exists anything that we could call nationality, which is rather a kind of conceptual construct which may be a part of an ideology.

Two notions of nationality were then discussed simultaneously:

(a) "Nationality" in the legal or administrative sense. Nationality is a theoretical quality ascribed by a particular legal system to a particular individual or set of individuals. It is obviously an abstract concept and does not necessarily correspond to any real fact. That fact is, however, recognized by a particular legal system as qualifying that particular individual for that particular nationality. In the modern state system with its notion of closed frontiers, nationality is one of the most important attributes of legal personality, as far as the individual in the western world is concerned. It is important in so far as the national legal systems adopt birth in a particular territory as a basis for qualifying for nationality.

(b) "Nationality" operating on a psychological level. In Africa, where the national communities in the nation-state sense are not as strong as in Europe, the concept of nationality operating on the psychological level, (the sense of belonging to a nation) may not be relevant yet. Identification is still along other lines, such as "cultural nationality", traditional nations, substate nations or ethnic groupings. Many boundary problems dexive from the tension between these two frameworks, the one being precise in the legal sense and the other imprecise. The question of having a nationality is not so important to the individual in Africa, except in cases of restrictions on labour migration, but it is important to the governments, who can use it as an always available tool for achieving some end or other.

But giving people a nationality is only one way of creating nations. Another necessary prerequisite is various types of cohesion, such as religious, administrative, social or economic (resource utilization). When these overlap to a certain extent, then we can expect boundaries to be stronger than when they 
do not strengthen each other. Thus, conflicts of a secessionist type occur when there is incompatibility between the administrative cohesion and all the other types of cohesion.

\section{Constellations of economic interests around boundaries}

The problem of constellations of interests around boundaries has often been discussed in terms of boundary conflicts. There are also similar constellations of interests around the economic functions of boundaries. The need for economic co-operation is being realized more and more in Africa and among the external powers involved in Africa, such as the EEC. The presence of the EEC in Africa has been of a disintegrative nature. Those of us who work in the non-associate countries and also in the ECA in Addis Ababa feel the disintegrative effect of the presence of the EEC in Africa. But on the part of the EEC one may also note some kind of change, especially in the rather old-fashioned concept of "Eurafrique", implying some kind of division of labour, with Europe as an industrial base and Africa as the provider of raw material. Under the pressure of economic circumstances this idea is now on the retreat and the EEC has carried out more thorough studies of the problems of industrialization in West and Central Africa than the ECA.

There is also a perceptible change in approach. Business and economic interests in Europe must push forward the creation of larger units in Africa, because without the creation of these units there will not be any great opportunity for selling industrial goods to Africa. However, the EEC has studied industrialization in Africa only in relation to its associate members, not taking into consideration the overall problem of the integration of the anglophone countries into some system of economic co-operation.

This may anyway be a realistic approach, because of the size of the group, maybe more realistic than the approach of the ECA, which prefers to start with smaller groupings. One point must be stressed: the size of these groupings must be properly understood. The purchasing power of some of the 
smaller groupings is inconsiderable, and they will probably have to be regrouped again, one way or another, in the not too distant future.

While many African states follow a policy of co-operation -and Tanzania was taken as a salient example-there is also a tendency to promote a policy of economic nationalism, an attempt to close the borders and to dismantle some previous forms of economic co-operation in order to push ahead with certain national development projects. Are these policies contradictory? In view of the long-term aims, can they be reconciled with the idea of reducing the importance of borders? That such economic measures have political repercussions in the short run is clear, but what will happen in the long run?

The two ideas are not contradictory. Some of the efforts made immediately after independence, for example, in Tanzania, to restrict economic trade with Kenya, were political moves to obtain the best possible terms in the new form of economic co-operation. Any country entering into economic co-operation with another will do this on the ground of its own interests and will assess the different forms of economic co-operation according to these interests. There may also be almost free trade (with some obstacles in the form of transit taxes) without having a completely free movement of capital or persons. This is not an ambivalent situation but a situation which corresponds at that particular moment to the interests of that particular state.

In discussing the advantages of integration, political scientists must discuss these advantages in a less ideal but more rational economic way and they will have to ask: Advantages to whom? Not only to which state but also to which groups inside these states and even to which external force outside these states. Different groups in a society look upon economic co-operation in different ways and we would also have to ask who stands to benefit from participating in different sorts of economic intergration, who loses, and what is the political leverage of each of these groups-government officials, trade unionists, military leaders, school-leavers, etc.? It may also be found that there is a greater cohesion among segments of so- 
ciety and groups of various kinds across state boundaries than, for example, between the government officials in one country.

They will have to ask these questions about advantages, because over the next five or six years any ruling group-good or bad, according to the system of values we apply-will be forced to enter into some type of co-operation. They may do it reluctantly, but they will have to do it. African politicians have now left the age of romantic dreaming and have arrived at a stage where they must start calculating the long-term advantages which, however obvious in a theoretical argument, are difficult to show empirically in the short run. Africa is slowly learning that.

In this context boundaries will have a very positive effect, because, whatever political ideology one adheres to, the role of the state in African development is very strong and important.

Paradoxically, what some would have called the hardening of the boundaries in Africa has contributed to the creation of more unity in a real sense, not a vague unity between small social units but a new and strong unity between states. We should, however, not entertain the possibility of large-scale political federation in Africa; even in East Africa it will be very difficult for a long time. There are still conflicting economic interests; most states still have internal problems of national integration and will be absorbed in home affairs for a long time. Maybe the economic realities will teach the politicians that the political preconditions for a federation, for example, in East Africa, are not now present.

The way to integration may therefore be through higher boundaries, tactically for the purpose of bargaining, not only for integration but for economic benefits in general. This brings out a growing awareness of national interests, of the component realities of economic and political life which the states are operating under, and of the use of these realities in a tactical sense towards bargaining for greater benefits. Raise the boundaries first and you can lower them afterwards and buy something with the consession. 


\section{South Africa and the "southern border"}

The problem of the "southern border" is not quite a boundary problem, but something far greater than that. It is an issue of fundamental politics and one could, of course, ask whether it is right to deal with this issue as a boundary problem in the "traditional" sense. On the other hand, the discussion of Professor Grundy's paper was concentrated on two issues, both of relevance to the question of economic co-operation and of nationality: external influences in the "southern-border" problems and South African expansionist policy towards Mozambique, Angola and Rhodesia.

Professor Benedict Mtshali was invited to comment on Professor Grundy's paper and he made the following comments:

Professor Grundy's approach is a sound one. $\mathrm{He}$ is not married to systems analysis, and uses only those aspects which can be validly applied. My main criticism of this tool, when rigorously applied to southern Africa, is that it runs up against this difficulty. The interaction of states is such that an input into one of them does not affect all of them, as would happen in a true system. The fact, of course, is that this happens only if South Africa is affected. Systems analysis, then, has a limited use, and to his credit Professor Grundy has realized this.

My major criticism of this paper is that, while realizing the dominant position of South Africa, it uses very few South African sources, especially the Afrikaans ones. As a result, many issues are untouched. I shall indicate some of them:

(1) How does South Africa view the "southern border"? An examination of South African Parliamentary Debates, Die Transvaaler, Die Burger, and two books by G. D. Scholtz would have shown that, from early in this century, South Africa has viewed the neighbouring territories as buffers against a world, potentially or actually, hostile to her. It is in this context that we should regard General Smuts's efforts to incorporate Rhodesia into South Africa in 1922.

(2) Following from the above, we have the fact that South Africa helps her neighbours only to the extent that they can 
maintain the integrity of their own borders. On their ability to do this depends South Africa's sense of security. It is in this sense that we must view South Africa's military presence in Rhodesia, which may well extend to Mozambique. If they are unable to maintain their borders, South Africa will feel obliged to help in Rhodesia and in Mozambique and Angola.

This is how one must interpret the South African intervention in Rhodesia. This is why there are moves already in South Africa to send troops both to Angola and Mozambique. These moves have been noted in Parliament ever since last year and are quite clear as far as Mozambique is concerned. Certain portions of territory are under the effective occupation of FRELIMO now and a month or two ago FRELIMO was reported to have opened up activities in the Tete area, which includes the Cabora Bassa dam. There are doubts in South Africa as to the ability of Portugal to fight on the fronts in the Tete area and in other parts of Mozambique. The Cabora Bassa dam will be very important in the near future to South Africa and Rhodesia. So there are moves to help Portugal to keep its boundaries intact, not because of any love of the Portuguese but because this is in South Africa's own interests.

(3) South Africa regards herself as being in a border-conflict situation. Thus, Zambia is described as fulfilling the same role as Jordan, i.e. harbouring terrorists (Die Burger, Cape Town, April 4 and 6,1968 ). Interestingly, the analogy of Jordan is used far more extensively. in Afrikaans than in English writings.

(4) The paper has little on the reaction of the liberation movements to the conflict between the southern regimes-the "white redoubt", to use Professor Carter's term-and the African border states, their hosts. Do these movements feel threatened and unsafe? Do they think they are embarrassing or even threatening the security of their hosts? Understandably, the aim of the "redoubt" is to destroy these movements before their forces infiltrate.

In this regard, interesting speculation can be made on the coup potential of Zambia or any other host country on the border. The redoubt countries, especially Rhodesia and South Africa, have threatened Zambia. But I think they would rather 
help to change present Zambian policy than intervene militarily. I think they would first encourage dissident elements and even put them in power, either through the ballot or through the bullet, i.e. by a military coup. Only if these means fail would they seriously contemplate their own military action.

(5) I also miss any mention of irredentist claims made in the South African border situation by Lesotho against South Africa and, interestingly, by the Transkei against the Republic, on a domestic boundary which has potential international implications. These claims are embarrassing to Pretoria, especially Matanzima's, which uses the apartheid argument against the creators of apartheid.

(6) I am unhappy about the treatment of South West Africa as an integral part of South Africa. South African sources regard this area as "the soft underside of the crocodile", because of the possibility that the outside world may use it to effect some change on the "southern border". They note with concern Zambia's role in this as a spring-board for UN action. More attention should also have been given to the role of the major world powers in maintaining or changing the "southern border".

(7) Finally, this paper leads to the question: What is the nature of the relationship among the southern African states? Could it be imperial? For academic research and political action, this question must still be answered.

Professor Mtshali's last point raised the very important and puzzling question, to what extent is South African policy turning into an aggressive policy and trying to push the "southern border" northwards? It is quite clear that there is a kind of South African economic offensive, for example, an increase in trade between South Africa and Mozambique and a diplomatic offensive in establishing diplomatic relationships with African states, such as Malawi. Although it may be true that South Africa has the skills to push the South African case a good deal more strongly in the rest of Africa, the current opinion in South Africa that the Republic will have some kind 
of relation with most of the other states in Africa before long may be questioned.

It is also a moot question whether South African policy will be aggressive, for a number of reasons. When South African police went into the Zambesi Valley in August 1967, they went in against ANC groups on their way back to South Africa. The question whether they would go in against ZAPU or ZANU fighting in Rhodesia would depend on events elsewhere. Events are rather important and "events" have been on South Africa's side recently: (a) The International Court decision deprived the opposition to the South African regime of the legal basis it had hoped for for further action, (b) the ArabIsraeli war and the closing of the Suez Canal emphasized the importance of Simonstown as a naval base, $(c)$ the failure of the sanctions on Rhodesia so far has been a big boost to South Africa, $(d)$ the recent immigration crisis in the United Kingdom gives the Vorster regime an opportunity to say "we told you so", (e) race riots and the assassination of Martin Luther King were indirectly and in the short run quite helpful to South Africa, $(f)$ Britain's economic crisis and the devaluation of the pound, and $(g)$ the inability of the British economy to withstand the kind of action that would be needed to change things in South Africa.

South Africa has benefited from many lucky breaks and today there is a great aura of confidence. It is a question, however, whether this aura envelops the South African Government, when it is considering its problems. They would weigh very carefully whether it would be wise to jeopardize the successes they have had by too expansionist a policy in Angola, Mozambique and Rhodesia. Verwoerd contemplated or was willing to contemplate the prospect of Rhodesia becoming a Bantustan under African majority rule and there are others in South Africa who say that they had better keep white rule as long as they can but that events would influence the ultimate decision. But the South African Cabinet has been so successful thus far that it would be very cautious about taking an aggressive step, for example, about going into Angola and Mozambique if Portuguese control began to collapse after the death of Salazar or if FRELIMO was about to encroach on vital econo- 
mic interests, such as the Cabora Bassa dam. To cross international frontiers in this way might destroy the successes they have had and bring about international intervention. As far as we know there are no defence agreements or treaties between Portugal or Rhodesia and South Africa which they could fall back on.

One cannot understand the problem of the "southern border" without looking at the external influence and the basis of external support for South Africa. The difficulty that Tanzania and Zambia had in financing the Tanzam railroad was used as an example. It was impossible to find money without turning to the Chinese. Why was that so? The Tanzam railroad may be a very simple case. Although it is very difficult to prove the political motives of the World Bank-as bankers, they are also clever in concealing their motives-it is clear that the application was turned down for very weak reasons. There was no real survey and only three or four cost estimates that differed very much. Even though some people as late as the beginning of 1967 thought that the Chinese were being used to persuade the western powers to finance the railroad, Tanzania later felt that, for political reasons, there was no way of getting the World Bank to support the railway, and therefore accepted the Chinese offer. This example of the railroad which illustrates the hard facts in the balance of power, also shows that a very unfavourable international constellation of interests exists in this part of Africa-unfavourable also to the African liberation movement. The liberation movement could not realistically expect economic sanctions to have an effect on South Africa, bearing in mind the extensive economic interests of the U.K. and the U.S.A.

In a Machiavellian way one should not blame the western powers for being such a system and constellation of interests. What one should blame them for is for having combined this position with a great hesitation in supporting the other part of the balance (the liberation movement). This is an operational answer. They may reply in legalistic terms that a foreign power cannot support intervention but that there are other ways of supporting it than by military intervention. The fact is that this hesitation, whatever its motives may be, has 
opened up this part of Africa for the Chinese involvement and it is now just beginning to be realized how deep this Chinese involvement way be. It is only recently that the present rulers of Zambia have started to see that this is helpful for them. They had hoped very much not to have to draw on this assistance, but suddenly found that very little else was available.

\section{Future border problems}

It would now seem that the really big boundary disputes and the big territorial claims, with some execeptions, are likely to disappear, but border incidents, difficulties in controlling population movements and debates on the nature and functions of borders can be expected to continue. We can expect occasional positional disputes concerning border rectification in cases in which it becomes evident, owing to more efficient administration of the border areas, that the delimitation was inaccurate or very unreasonable and has an effect which tends to disturb the local life. It may have been overlooked during a long period, because the administration was not effective.

Border rectification and other problems of this nature may also arise out of other differences between governments. We have seen that some border disputes have arisen and then subsided in relation to government changes.

It is conceivable that some larger territorial claims may arise as a result of the discovery of important resources near the border region. We do not know exactly what the relationship is between the political claim, the historical claims and the location of resources along the border, but it is still very relevant to remember that in many of the cases of border conflict there was some coincidence between the location of important resources along the frontier line and the border disputes. This has been mentioned in connection with the Morocco-Algeria dispute and it was an important fact in the dispute between the Congo and Gabon. In the case of the secession of Biafra from Nigeria one can point to the location of very important oil resources in the east. Even at the lower level of local subsistence economy, disputes involve grazing 
areas and wells, as was the case both in the Somali-Ethiopian dispute and the Mali-Mauritania dispute. Location or discovery of resources may affect the attitudes of governmenst towards their borders. Secession could also be affected by the processes of national integration. If national integration proceeds smoothly and most of the important groups and regions have the feeling that they are part of the nation, such problems can be overcome, but if in any unfortunate turn of events some section or group of people feels that they are not getting their fair share of the available resources or that they are being discriminated against, they may remember that they are different and may wish to secede, or they may wish to link $u_{p}$ with some other group on the other side of the border.

\section{Priorities for further research}

The discussion on this point was not at all conclusive but, as usual in conferences, it was generally felt that much more research was needed, in order to get to know more about boundary problems and in order to be able to make predictions and projections into the future. The participants in the seminar felt that the following lists of research ideas or projects had some priority:

(1) The problem of border regimes. We know very little about what the actual border regimes are and no research at all has been done on them.

(2) A similar research project would be to investigate the problems of border populations. As we look at various aspects of the evolution into nationhood of developing African countries, it would be worth looking into the effect of the border on border populations in this respect especially.

(3) The implications of the effects of borders on the growing tendencies towards economic regionalism. The discussion on this point has been referred to above. In this context it was also mentioned that this type of economic development has implications for, for example, the US aid policy to Africa, in which today something that "has the word regional in it is bound to get a better hearing in terms of AID policy than something that does not". 
(4) Someone, preferably a Scandinavian scholar, should look into the concept of "regionalism" in the American aid programme and investigate whether this is an excuse for cutting down that programme and to what extent it goes beyond an excuse into being a philosophical doctrine with practical results in really helping and promoting regionalism in Africa. One part of the study would be to examine the new regional projects, if any, that the U.S.A. is now supporting and compare them with those they were supporting five years ago.

(5) Someone should look into the problem of whether it is recommendable for a great power to try to influence African leaders to move towards regionalism or whether that is the kind of thing that an international body like the UN of its specialized agencies ought to try to induce African countries to undertake. The great powers might then give more aid to international agencies for this kind of project.

(6) It was also stressed in this connection that the problem of regionalism as a whole is very difficult, because the capacity of regional organizations to come forward with properly prepared aid projects is, at the moment, very limited everywhere in Africa. To further regionalism one cannot wait for multilateral applications from several states or through their common organizations. If any power outside Africa pursues a "regionalist" policy, it will have to find another formula for its support than the existing regional institutions. It will have to analyse the possible regions and then give a form of bila. teral assistance which will further the integration of larger regions, as has been the case with the present negotiations to form some kind of agricultural region of the northern parts of the Ivory Coast, and Ghana with Upper Volta. The same is true of Central Africa. One would have to reduce the support for the industrial development of the coastal region and, if one wants regional development, increase the support for the interior. In East Africa regionalism will have to look to a fairly even development of the three states. There is a problem concerning the land-locked states. In September 1966, when a UN resolution to give Lesotho a corridor to the sea to diminish its dependence on South Africa was discussed, all the Latin American delegates voted against it. A comparison 
with Latin American experience and the problems of the landlocked states there may have some interest or relevance in comparison with Africa today.

(7) The boundary zone (the shutter zone or the boundary depth) is one of the characteristics of traditional African boundaries. Africa may learn to experiment by bringing back a notion that its own traditional history has evolved. African states are experimenting with new forms of political relations and institutions and we may be able to see in the idea of the boundary in depth, as in some other ideas, a useful kind of new experimentation in fields in which the rest of the world has run out of ideas.

(8) Policy-oriented research on the questions of the "southern border": a study of the possibilities of multilateral development of the former High Commission territories (Lesotho, Botswana and Swaziland) as a means of helping them to maintain their influence and to avoid becoming economic backwaters. It is hoped that multilateral involvement in a big way here might have an influence on the South Africans and give them a feeling or a sense of pressure which may be more important than sanctions that do not work.

(9) Which factors determine the dynamics in a situation which might draw South Africa into an expansionist foreign policy, not in the sense of taking territory but in establishing a South African sphere of influence? Which are the factors which would tend to hold it back from going too far? Such an inquiry would lead to a conclusion which would measure to what extent the reality of a threat is there.

(10) Details on the operation of foreign interests in Africa which have a general bearing on boundary problems. 


\section{Robert Waters}

\section{Inter-African Boundary Disputes}

\begin{tabular}{|c|c|c|c|}
\hline States & Area & Miles (approx.) & Dates \\
\hline I. Morocco-Algeria & $\begin{array}{l}\text { The "confins" between Colomb } \\
\text { Béchar and the western Tarfaya } \\
\text { boundary }\end{array}$ & 350,000 sq.m. & $1956-$ \\
\hline 2. Morocco-Mauritania & Spanish Sahara & 102,703 sq.m. & I956- \\
\hline 3. Morocco-Mauritania & State of Mauritania & 4 19,000 sq.m. & $1956-$ \\
\hline 4. Morocco-Mali & Northeastern Mali & I 50,000 sq.m. & I $95^{6-61}$ \\
\hline 5. Tunisia-Algeria & $\begin{array}{l}\text { Triangle of the Great Eastern } \\
\text { Erg, south of Tunisia }\end{array}$ & I5,000 sq.m. & $\begin{array}{l}195^{6-64} \\
1966\end{array}$ \\
\hline 6. Ghana-Togo & Former German Togo & 28,000 sq.m. & $\times 956-66$ \\
\hline 7. Ghana-Ivory Coast & $\begin{array}{l}\text { "Sanwi State" in southeastern } \\
\text { corner of Ivory Coast }\end{array}$ & $250 \mathrm{sq} . \mathrm{m}$. & $1959-66$ \\
\hline 8. Ghana-Upper Volta & Parts of border between them & 50-mile strip & $1964-66$ \\
\hline 9. Mali-Upper Volta & Marshy border strip south of Gao & 9o-mile border & I 963 \\
\hline Io. Niger-Upper Volta & $\begin{array}{l}\text { Entire border from Mali to } \\
\text { Dahomey border }\end{array}$ & 216-mile border & $1963-64$ \\
\hline \multirow{3}{*}{$\begin{array}{l}\text { I 1. Dahomey-Niger } \\
\text { 1 2. Mali-Mauritania }\end{array}$} & Island of Lete in Niger River & 5-mile border & I $963-65$ \\
\hline & $\begin{array}{l}\text { (a) Hodh desert border between } \\
\text { the two countries }\end{array}$ & $65^{\circ}$ miles long & I $95^{8-63}$ \\
\hline & $\begin{array}{l}\text { (b) Savannah region from Djel } \\
\text { Mael to Queneibe }\end{array}$ & $3,125 \mathrm{sq} . \mathrm{m}$ & $195^{8-63}$ \\
\hline 13. Liberia-Guinea & Mount Nimba Region & 300 sq.m. & 1958 \\
\hline I4. Liberia-Ivory Coast & $\begin{array}{l}\text { Area between Cess and Cavally } \\
\text { Rivers }\end{array}$ & 950 sq.m. & I96o \\
\hline $\begin{array}{l}\text { I5. United Arab Republic- } \\
\text { Sudan }\end{array}$ & $\begin{array}{l}\text { Wadi Halfa salient; the Jabel } \\
\text { Bartazuga-Korosko rectangle; } \\
\text { and the Sarra triangle }\end{array}$ & $7,500 \mathrm{sq} . \mathrm{m}$ & $195^{8}$ \\
\hline I6. Somali Rep.-Ethiopia & Haud and Ogaden Regions & $60,000 \mathrm{sq} . \mathrm{m}$. & 1955- \\
\hline I7. Somali Rep.-Ethiopia & All of French Somaliland & 8,494 sq.m. & $1960-$ \\
\hline
\end{tabular}




\section{States}

Area

Miles (approx.)

Dates

18. Somali Rep.-Kenya

Northern Frontier District of Kenya

19. Kenya-Ethiopia

Arid border region of Gadaduma wells

20. Kenya-Zanzibar

From Tanganyika line to Kidini, 2,00o-mile strip $\quad$ I 963 including Lamu Islands and

Mombasa

21. Kenya-Uganda

Border between them

22. Mozambique-Malawi

Marshy eastern shore of Lake Shirwa

23. Congo (Brazzaville)- Gold mine region south of Gabon Franceville

24. Cameroun-Gabon Rio Muni

25. Cameroun-Nigeria Former British North Cameroon

26. Cameroun-Nigeria

27. Lesotho-South Africa

28. Sudan-Chad

29. Sudan-Central

African Republic

30. Sudan-Ethiopia

Island of Fernando Po

31. Nigeria-Dahomey

Yoruba area of Dahomey

50,000 sq.m . I960-

50-mile strip $\quad 1963$

Island of Fernando Po

32. Tanzania-Malawi

The Lake Nyasa (Malawi) border

$5^{60-m i l e ~ b o r d e r ~} \quad 1962$ 90 sq.m. $\quad 1962$

100 sq.m. I964-

ro,045 sq.m. $\quad$ 1960 I $960-6$ I

785 sq.m. $\quad$ I $960-61$

845 -mile border region

725-mile border region

Parts of

I,460-m. border

1960

I 962

discussed

r 967

officially

raised 


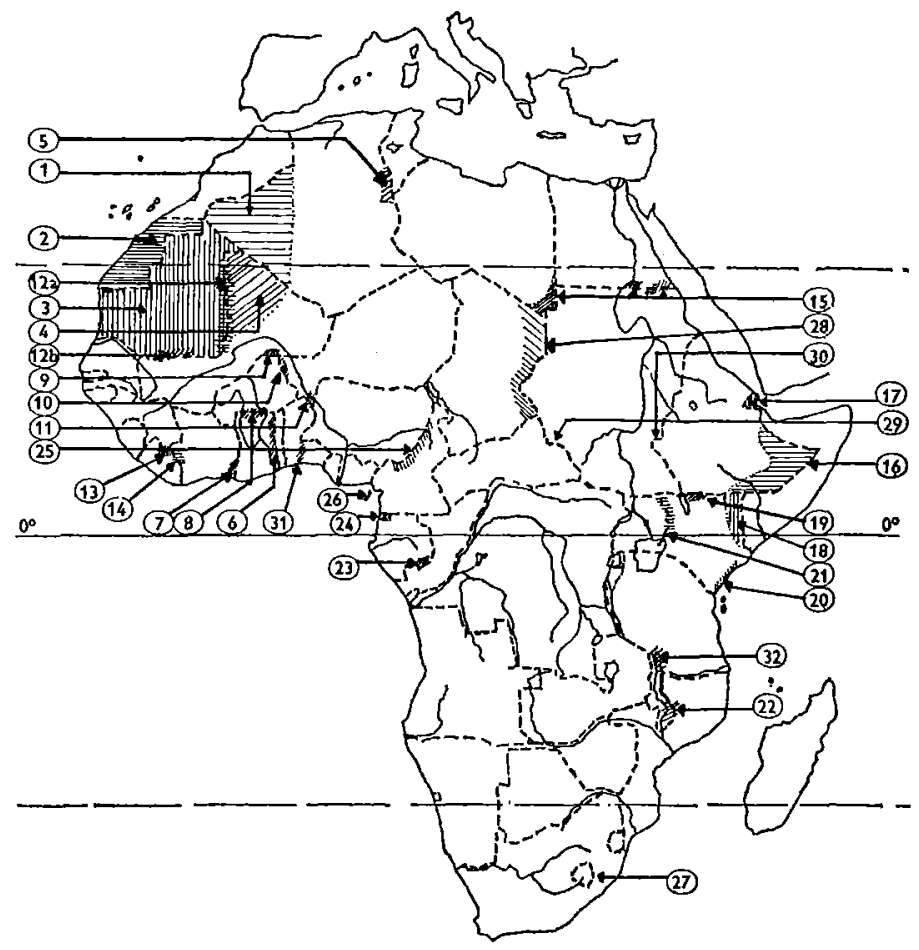

The figures on the map are those shown in the table on pp. $183-84$. 


\section{The Length and Status of International Boundaries in Africa}

\begin{tabular}{|c|c|c|}
\hline $\begin{array}{l}\text { Sovereignty } \\
\text { (on either side) }\end{array}$ & $\begin{array}{l}\text { Length } \\
\text { (miles) }\end{array}$ & Status \\
\hline Algeria-Libya & 610 & Delimited \\
\hline Algeria-Mali & 804 & Delimited \\
\hline Algeria-Mauritania & $3^{00}$ & Delimited \\
\hline Algeria-Morocco & 930 & $\begin{array}{l}\text { Inland from Mediterranean de- } \\
\text { marcated } 102 \text { miles to hill of } \\
\text { Tenict Sassi, then delimited } \\
\text { about } 200 \text { miles to Figuig, re- } \\
\text { mainder disputed }\end{array}$ \\
\hline Algeria-Niger & 600 & Delimited \\
\hline Algeria-Spanish Sahara & 20 & $\begin{array}{l}\text { Demarcated; precise location of } \\
\text { Morocco tripoint unknown }\end{array}$ \\
\hline Algeria-Tunisia & $5^{85}$ & $\begin{array}{l}\text { Inland from Mediterranean de- } \\
\text { marcated for } 404 \text { miles to Bir } \\
\text { Romane, remainder disputed }\end{array}$ \\
\hline \multicolumn{3}{|l|}{ Angola-Congo (Braz.) } \\
\hline (Cabinda) & 116 & Demarcated \\
\hline Angola-Congo (Kin.) & 1,485 & Demarcated \\
\hline Angola-South West Africa & 830 & Demarcated \\
\hline Angola-Zambia & 710 & Demarcated \\
\hline Botswana-Rhodesia & 465 & Demarcated \\
\hline Botswana-South West Africa & 845 & $\begin{array}{l}\text { Delimited and mostly demar- } \\
\text { cated }\end{array}$ \\
\hline Botswana-South Africa & 1,035 & Demarcated \\
\hline Burundi-Congo (Kin.) & 145 & Demarcated \\
\hline Burundi-Rwanda & 180 & Delimited \\
\hline Burundi-Tanzania & 280 & Demarcated \\
\hline \multicolumn{3}{|l|}{ Cameroon-Central African } \\
\hline Republic & $4^{88}$ & Delimited \\
\hline
\end{tabular}




\begin{tabular}{|c|c|c|}
\hline $\begin{array}{l}\text { Sovereignty } \\
\text { (on either side) }\end{array}$ & $\begin{array}{c}\text { Length } \\
\text { (miles) }\end{array}$ & Status \\
\hline Cameroon-Chad & 680 & Delimited \\
\hline Cameroon-Congo (Braz.) & 317 & Delimited \\
\hline Cameroon-Equatorial Guinea & 120 & Demarcated \\
\hline Cameroon-Gabon & 162 & Delimited \\
\hline Cameroon-Nigeria & 1,085 & Demarcated \\
\hline \multicolumn{3}{|l|}{ Central African Republic- } \\
\hline Chad & 695 & Delimited \\
\hline \multicolumn{3}{|l|}{ Central African Republic- } \\
\hline Congo (Braz.) & 277 & Delimited \\
\hline \multicolumn{3}{|l|}{ Central African Republic- } \\
\hline Congo (Kin.) & 892 & Demarcated \\
\hline Central African Republic- & & \\
\hline Sudan & 725 & Delimited \\
\hline Ceuta-Morocco & 4 & Demarcated \\
\hline Chad-Libya & 655 & Delimited \\
\hline Chad-Niger & 730 & Delimited \\
\hline Chad-Nigeria & 50 & Demarcated \\
\hline Chad-Sudan & 845 & Delimited \\
\hline Congo (Braz.)-Congo (Kin.) & 975 & Demarcated \\
\hline Congo (Braz.)-Gabon & 1,105 & Delimited \\
\hline Congo (Kin.)-Rwanda & 135 & Demarcated \\
\hline Congo (Kin.)-Sudan & $39^{\circ}$ & Demarcated \\
\hline Congo (Kin.)-Tanzania & 285 & Demarcated \\
\hline Congo (Kin.)-Uganda & 426 & Demarcated \\
\hline Congo (Kin.)-Zambia & $1,35^{0}$ & Demarcated \\
\hline Dahomey-Niger & 87 & Delimited \\
\hline Dahomey-Nigeria & 455 . & Demarcated \\
\hline Dahomey-Togo & 340 & Delimited \\
\hline Dahomey-Upper Volta & 182 & Delimited \\
\hline Equatorial Guinea-Gabon & 215 & Demarcated \\
\hline Ethiopia-French Somaliland & 284 & Demarcated \\
\hline Ethiopia-Kenya & 490 & $\begin{array}{l}\text { Demarcated, but Ethiopia has } \\
\text { not accepted demarcation of } \\
1947\end{array}$ \\
\hline Ethiopia-Somali Rep. & 994 & $\begin{array}{l}\text { Partially demarcated; remainder } \\
\text { disputed or delimited as pro- } \\
\text { visional administrative boun- } \\
\text { dary between Dolo and inter- } \\
\text { section of } 8^{\circ} \mathrm{N} \text {. and } 4^{\circ} \mathrm{E} \text {. }\end{array}$ \\
\hline
\end{tabular}




\begin{tabular}{|c|c|c|}
\hline $\begin{array}{l}\text { Sovereignty } \\
\text { (on either side) }\end{array}$ & $\begin{array}{l}\text { Length } \\
\text { (miles) }\end{array}$ & Status \\
\hline Ethiopia-Sudan & 1,460 & Demarcated \\
\hline \multicolumn{3}{|l|}{ French Somaliland- } \\
\hline Somali Rep. & 36 & Demarcated \\
\hline Gambia-Senegal & 459 & Demarcated \\
\hline Ghana-Ivory Coast & 430 & Demarcated \\
\hline Ghana-Togo & $5^{15}$ & Demarcated \\
\hline Ghana-Upper Volta & 355 & Demarcated \\
\hline Guinea-Ivory Coast & 351 & Demarcated \\
\hline Guinea-Liberia & 312 & Delimited \\
\hline Guinea-Mali & 534 & Delimited \\
\hline Guinea-Portuguese Guinea & 235 & Demarcated \\
\hline Guinea-Senegal & 173 & Delimited \\
\hline Guinea-Sierra Leone & 415 & Demarcated \\
\hline Ifni-Morocco & 71 & Delimited \\
\hline Ivory Coast-Liberia & 298 & $\begin{array}{l}\text { Demarcated, except delimited } \\
\text { between Noun and Cavally } \\
\text { Rivers }\end{array}$ \\
\hline Ivory Coast-Mali & 200 & Delimited \\
\hline Ivory Coast-Upper Volta & 324 & Delimited \\
\hline Kenya-Somali Rep. & 424 & Demarcated \\
\hline Kenya-Sudan & 140 & Delimited \\
\hline Kenya-Tanzania & 478 & Demarcated \\
\hline Kenya-Uganda & $5^{60}$ & $\begin{array}{l}\text { Demarcated, except in central } \\
\text { section }\end{array}$ \\
\hline Lesotho-South Africa & 500 & Delimited \\
\hline Liberia-Sierra Leone & 165 & Demarcated \\
\hline Libya-Niger & 220 & Delimited \\
\hline Libya-Sudan & 298 & Delimited \\
\hline Libya-Tunisia & 297 & Demarcated \\
\hline Libya-United Arab Republic & 693 & Part demarcated, part delimited \\
\hline Malawi-Mozambique & 868 & Demarcated \\
\hline Malawi-Tanzania & 520 & Demarcated \\
\hline Malawi-Zambia & 520 & Delimited \\
\hline Mali-Mauritania & 1,390 & Delimited \\
\hline Mali-Niger & 513 & Delimited \\
\hline Mali-Senegal & 279 & Delimited \\
\hline Mali-Upper Volta & $75^{8}$ & Delimited \\
\hline Mauritania-Senegal & 505 & Demarcated \\
\hline Mauritania-Spanish Sahara & 970 & Demarcated \\
\hline
\end{tabular}




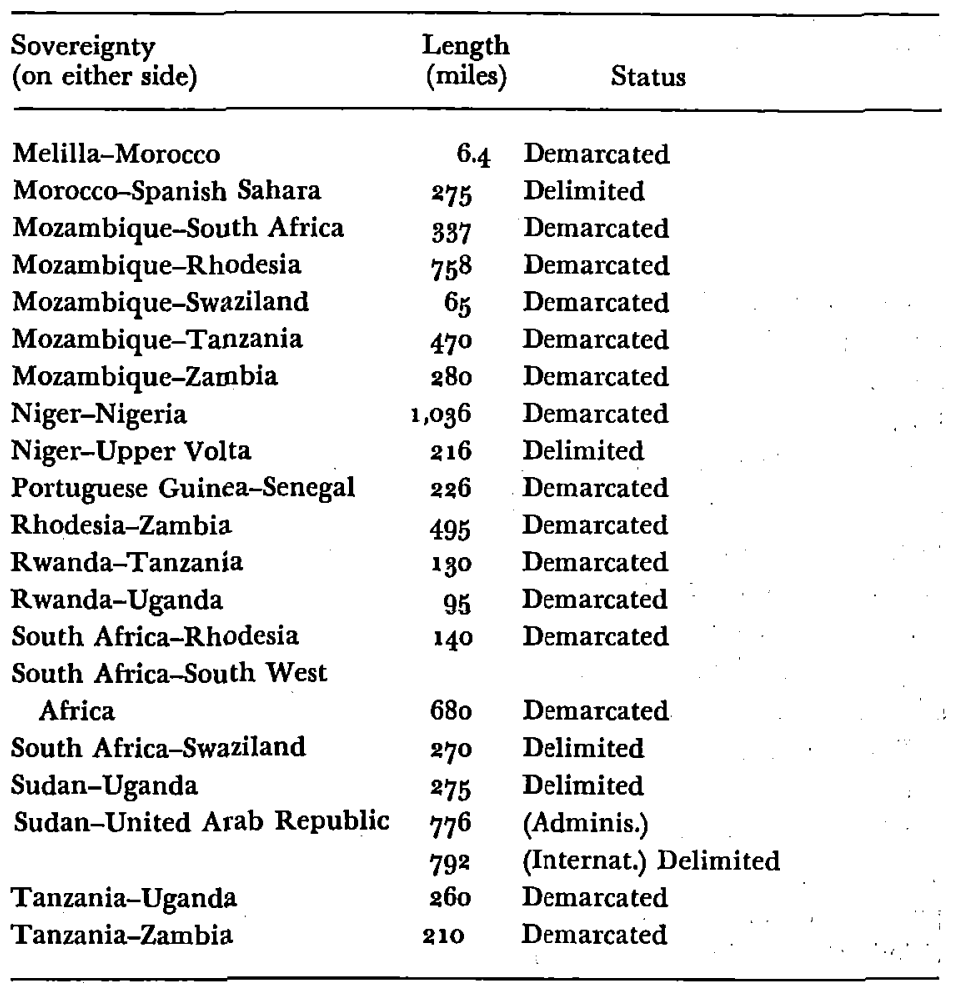

Assistance by Howard University and the Office of the Geographer, U.S. Department of State, is hereby acknowledged. Reprinted with permission from African Studies Bulletin, Vol. X: 2, September 1967. 


\section{Contributors}

Anthony Allott is Professor of African Law at the School of Oriental and African Studies, University of London, and the author of several books and articles on problems of African law.

Samuel Chime, is a research student at the University of Stockholm. Since 1966 he has been engaged on a study of the Organization of African Unity, on which subject he recently submitted a doctoral thesis.

Anatolii A. Gromyko is head of the International Problems Department of the Africa Institute of the National Academy of Sciences, Moscow.

Kenneth W. Grundy is Associate Professor of Political Science at Case Western Reserve University, Cleveland, Ohio. During the $1967-8$ academic year he was on leave, serving as Visiting Senior Lecturer at Makerere University College, Kampala, Uganda. His published work includes a monograph entitled Conflicting Images of the Military in Africa and a number of papers which have appeared in journals and books in Ganada, Japan, Kenya, the Netherlands, Uganda, the United Kingdom, and the United States.

Knud Erik Svendsen was for some years lecturer in economics at the University of Copenhagen. In 1964 he went to the University College, Dar es Salaam, Tanzania, as Professor of Economics. In 1967 he became Research Professor at the Economic Research Bureau in Dar es Salaam, working on problems of decision-making in economic policy and planning. He has written on the economic systems of the Soviet Union and Poland, on economic theory and on planning in developing countries.

Saadia Touval is Senior Lecturer in Political Science at Tel Aviv University in Israel. $\mathrm{He}$ is the author of Somali Nationalism and is now writing a book on border problems in Af- 
rica. He has travelled widely in Africa to do research on boundary problems.

Sven Tägil is Associate Professor of History in the University of Lund and is currently involved in a research programme on the theoretical issues of border problems.

Jokica Hadži-Vasileva is a member of the Institute of the Study of the Workers' Movement in Belgrade and the author of Le système du parti unique en Afrique.

I. William Zartman received his graduate education from the Johns Hopkins University, the University of Copenhagen and Yale University with a Ph.D. in 1956. He is Professor of Government and Associate Director of the Center for International Studies at New York University, and Executive Secretary of the Middle East Studies Association. His books include: Problems of New Power 1964, Destiny of a Dynasty 1964, Government and Politics in Northern Africa 1963, and International Relations in the New Africa 1966. 


\section{Notes}

Sven Tägil, pp. 27-32

1. S. W. Boggs, International Boundaries (New York 1940), pp. 2526.

2. N. Pounds, Political Geography (New York 1963), pp. 61-65.

3. J. R. V. Prescott, The Geography of Frontiers and Boundaries (London 1965), p. 109.

4. Q. Wright, $A$ Study of War (Chicago 1942), p. 998.

5. Q. Wright, op. cit., p. 999.

6. K. W. Deutsch, Nationalism and Social Communication (New York 1952), p. $7^{8}$.

7. Cf. L. H. Niléhn, "Några synpunkter på gränser och gränskonflikter" (duplicated paper, Institute of History, Lund, 1968).

8. Cf. L. H Niléhn, op. cit., p. 12.

9. E. Fischer, "On Boundaries", World Politics, Vol. 1, p. 196.

10. L. F. Richardson, Statistics of Deadly Quarrels (London 1960).

11. K. Boulding, Conflict and Defense: A General Theory (New York 1962).

12. L. H. Niléhn, op. cit., pp. 24-31.

Knud Erik Svendsen, pp. 33-64

1. The main sources of reference have been: A. T. Grove, Africa South of Sahara, London 1967; William A. Hance, The Geography of Modern Africa, New York 1964; Arthur Hazlewood (ed.), African Integration and Disintegration: Case Studies in Economic and Political Union, London 1967; Regional H. Green and Ann Seidmann, Unity or Poverty? The Economics of Pan-Africanism, London 1968. The main sources of current information have been: Le Moniteur Africain du Commerce et de l'Industrie (Dakar, weekly); Marchés Tropicaux et Mediterranéens (Paris, weekly); Nouvelle Afrique (Dakar, weekly); West Africa (London, weekly), Africa Report (New York, monthly); Bulletin de l'Afrique Noire (Paris, weekly), Translations on Africa (Washington, irregular), Banque Centrale des 
Etats de l'Afrique de l'Ouest, Notes d'Information et Statistiques (Paris, monthly); Cameroun-Afrique Equatoriale, Banque Centrale, Etudes et Statistiques (Paris, monthly); ECA, Foreign Trade Newsletter (Addis Ababa, irregular); Africa Research Bulletin (London).

2. Hilda Kuper (ed.), Urbanization and Migration in West Africa, Berkeley, ${ }^{1965}$ (articles by I. Wallerstein and Elliot J. Berg).

3. Suzanne Bozon, "Modernisation et conflicts tribaux in Afrique noire", Revue Française de Science Politique (Paris), October, 1967.

4. Secretariat of UNGTAD, Trade Expansion and Economic Integration among Developing Countries. New York 1967, TD/B/85/ Rev.1.

5. IMF, International Financial News Survey, February 10, 1967.

\section{William Zartman, pp. 79-100}

1. For basic discussions of African boundary problems, see Saadia Touval, "Africa's Frontiers: Reactions to a Colonial Legacy", International Affairs 4: 641-54 (October 1966); Ravi Kapil, "On the Conflict Potential of Inherited Boundaries in Africa", World Politics 4: 656-73 (July 1966); I. William Zartman, "The Politics of Boundaries in North and West Africa", Journal of Modern African Studies 2: $155-73$ (1965). Useful references cited in these three articles are re-cited here only when specifically relevant.

2. See Philippe Husson, La Question des Frontieres Terrestres du Maroc (CIB, 4 rue du Bouloi, Paris I, 1960), 72; I. William Zartman, "The Sahara-Bridge or Barrier?", International Conciliation 541, Jan. 1963, 42-47; Maurice Flory, "La notion du térritoire arabe et son application au problème du Sahara", Annuaire Français de Droit International 3: 73-91 (1957).

3. L'Opinion (Rabat), 12 October 1967.

4. See Saadia Touval, Somali Nationalism (Cambridge: Harvard U.P., 1963); John Drysdale, The Somali Dispute (New York: Praeger, 1964); Alexander Melamid, "The Kenya-Somalia Boundary Dispute", Geographical Review 4: 586-88 (1964); Mesfin Wolde Marian, "Background to the Ethiopia-Somalian Boundary Dispute", Journal of Modern African Studies 2:189-219 (1964); A. A. Castagno. "The Somali-Kenyan Controversy", ibid., 165-88; I. M. Lewis, "Pan-Africanism and Pan-Somalism", ibid. 2: 147-61 (1963).

5. Radio Kenya, 23 January 1967.

6. See the forthcoming proceedings of the St. Johns University (New York) Conference on African Refugees, November 1967 , Hugh Brooks (ed.), for pertinent cases and comparisons. 
7. See discussions in Claude WeIch, The Dream of Unity (Ithaca: Cornell U.P. 1965).

8. There is also the Lake Nyasa boundary of Tanzania, discussed in the paper of Professor Touval at the present conference.

9. L'Effort Camerounais, 26 October 1966.

10. Agence France-Presse, 13 June 1965, denied by the Sudan, Le Monde (Paris, 21 June 1965).

11. On the rationale of intervention in Africa, see I. William Zartman, "Intervention among Developing States", Journal of International Affairs 2: 188-197 (1968).

12. For further discussions, see I. William Zartman, International Relations in the New Africa (Englewood Cliffs: Prentice-Hall, 1966) and "Africa as a Subordinate State System in International Relations", International Organization 3: 545-64 (1967).

13. The first international support for Morocco was from the League; see Jamal Sa'd, The Problem of Mauritania (New York: Arab Information Center, 1960; Information Paper 4).

14. Thus major de-escalation agreements-Bamako 1963, Arusha 1967, Khartoum 1964-refer to the means of conflict, not to the issue at stake.

15. See the excellent article by Saadia Touval, "The Organization of African Unity and African Borders", International Organization 1: $102-27(1967)$, and the rosier study of Patricia B. Wild, "The $\mathrm{OAU}$ and the Algerian-Moroccan Border Conflict", International Organization 1: 18-36 (1966).

16. Ethiopia-Kenya, 26 September 1963; Cameroun-Nigeria, 3 April 1966; the Sudan-Ethiopia, 2 April 1966, for example. However, Ghana is one of the several states in Africa all of whose borders are demarcated, which at most raises the question "So what?" and at least suggests that such agreements can be called into question.

17. Kenya-Somalia, 27 October 1967; the Sudan-Central African Republic, 25 May 1966; Senegal-Guinea and Senegal-Mauritania; the Sudan-Ethiopia, 2 April 1966; the Sudan-Chad, 14 October 1966; among others.

\section{Saadia Touval, pp. Ior-I 18}

1. Cameroun, although formally unreconciled to the integration of British Northern Cameroon within Nigeria, has not pursued in practice irredentist policies, and is therefore not listed as an irredentist state. 
2. Cf. I. William Zartman, "Characteristics of Developing Foreign Policies", in W. H. Lewis (ed.), French-Speaking Africa. New York: Walker and Co., 1965, p. $19 \%$.

3. Lord Curzon of Kedleston, Frontiers. The Romanes Lectures, Oxford, 1907 .

4. The view that the border had been altered was denied by the Tanganyikan Prime Minister in a statement in Parliament on June 11, 1962. See Tanganyika, Parliamentary Debates, First Session, June 11, 1962, cols. 263-264.

5. R. Emerson, Self-Determination Revisited in the Era of Decolonization. Cambridge, Mass.: Harvard University, Center for International Affairs, Occasional Papers in International Affairs, No. 9. December 1964 .

6. OAU Doc. AHG/Res. 16 (I). See S. Touval, "The Organization of African Unity and African Borders", International Organization, Vol. XXI, No. 1 (1967).

7. Nkrumah's interest in the Nzima partition is reflected in his autobiography. See K. Nkrumah, The Autobiography of Kwame Nkrumah. Edinburgh: Thomas Nelson and Sons, 1957, p. 264 and map on p. $26 \mathrm{~g}$.

8. L. Rubin and P. Murray, The Constitution and Government of Ghana. London: Sweet and Maxwell Ltd., 1961, pp. 32-33.

9. Ghana Today, March 23 and April 20, 1966.

10. Cf. A. A. Castagno, "The Political Party System in the Somali Republic", in J. S. Coleman, and C. Rosberg (eds.), Political Parties and National Integration in Tropical Africa. Berkeley and Los Angeles: University of California Press, 1964, pp. 533, 539-540, 554. See also R. L. Kapil, "On the Conflict Potential of Inherited Boundaries in Africa", World Politics, Vol. 18, No. 4 (July 1966).

1x. I. William Zartman, International Relations in the New Africa. Englewood Cliffs: Prentice-Hall, 1966, p. 52.

12. D. E. Ashford, "The Irredentist Appeal in Morocco and Mauritania", Western Political Quarterly, Vol. 15 (December 1962). See also D. Thiam, The Foreign Policy of African States. London: Phoenix House, 1965, pp. xi-xii.

13. Castagno, op. cit., p. 548, See also I. M. Lewis, "Pan-Africanism and Pan-Somalism", Journal of Modern African Studies, Vol. 1, No. 2 (June 1963), pp. $156-157$. 
Kenneth W. Grundy, pp. I I9-16o

1. On the Republic at the U.N., consult J. E. Spence, Republic Under Pressure: A Study of South African Foreign Policy (London: Oxford University Press, 1965), pp. 100-18.

2. The only direct diplomatic representation between north of the border black Africa and a white southern-African state was servered in October 1966, when the Congo broke off relations with Portugal.

3. Africa Research Bulletin (hereafter cited as $A R B$ ), IV, No. 8 (August, 1967), pp. $835 \mathrm{C} \& 8 \mathrm{~g} 8 \mathrm{~B}$.

4. Ibid., IV, No. 1 (January, 1967), p. 695.

5. Ibid., IV, No. 6 (June, 1967), p. 793.

6. Ibid., I, No. 1 (January, 1964), p. 3A; and I, No. 4 (April, 1964), p. 53 A.

7. Uganda Argus (Kampala), February 10, 1968; and Reporter (Nairobi), VIII, No. 205 (February 23, 1968), pp. 12-13.

8. East African Standard (Nairobi), October 19, November 2, and December 23, 1964; and Tanganyika Standard (Dar es Salaam), December 22 \& 31, 1964. See also Africa Report, XII, No. 3 (March, 1967), p. 27 .

9. East African Standard, June 15 \& $16,1965$.

10. Malawian insurgents were allegedly recruited in Tanzania by Chisiza, taken to Zambia for training, and then sent into Malawi from the Fort Jameson district of Zambia. $A R B$, IV, No. 10 (October, 1967 ), p. $887 \mathrm{~A}-\mathrm{B}$; and IV, No. 11 (November, 1967), p. 903AB.

11. The Nationalist (Dar es Salaam), October 27, 1965 .

12. $A R B$, IV, No. 5 (May, 1967 ), p. 775 A; No. 6 (June, 1967), p. $794 \mathrm{~B}$; and No. 7 (July, 1967), p. 817A-B.

13. Africa Diary (New Delhi), VI, No. 11 (March 7-13, 1966), p. 2767; hereafter cited as $A D$.

14. For example, see ibid., VII, No. 32 (August 6-12, 1967), p. 3515 .

15. Banda's own label as quoted in $A R B$, IV, No. 5 (May, 1967), p. $773^{\mathrm{C}}$.

16. See, for instance, Dr. H. Kamazu Banda, Malawi Congress Party Convention 1967: Opening Address by President of Malawi (n.p.: Department of Information, 1967), pp. 16-20. At this Congress he announced his intention to open diplomatic relations with South Africa. He concluded his address: "Certain people in certain countries will howl and snarl against our intention to open a Legation in South Africa ... I am totally indifferent to howling and snarlings, whether by and from hyenas or jackals, leopards or lions." 
17. Information for this account was compiled from several sources, including $A D$ and $A R B$, and from several secondary accounts, among them George M, Houser, "Nationalist Organizations in Angola: Status of the Revolt", and John A. Marcum and Allard K. Lowenstein, "Force: Its Thrust and Prognosis", both in John A. Davis and James K. Baker (eds.), Southern Africa in Transition (New York: Praeger, 1966), pp. 157-79 \& 247-77 respectively; Anonymous, "Realities of Angolan Struggle", The New African, VI, No. 2 (October, 1967), pp. 10-14; Colin Legum, "Guerilla Warfare and African Liberation Movements", Africa Today, XIV, No. 4 (August, 1967), pp. 5-10; and "Drums against White Africa", The Times (London), March 11, 1968, p. 8. For a useful treatment of the applicability of the theory of guerrilla warfare to southern Africa, see Martin Legassick, "The Consequences of African Guerrilla Activity for South Africa's Relations with her Neighbors", a paper presented to the annual meeting of the African Studies Association, New York, November 3, 2967 (16 pp., mimeographed). See also John A. Marcum, "Three Revolutions", Africa Report, XII, No. 8 (November, 1967$)$, pp. 8-12, for an excellent discussion of inter- and intragroup politics.

18. As quoted in Marcum \& Lowenstein, op. cit., p. 252.

19. $A D$, II, No. 37 (September 8-14, 1962), p. $74^{1}$.

20. Who at that time numbered 1,300. The Times (London), November 26,1962 .

21. $A D$, II, No. 42 (October 13-19, 1962), p. 799 .

22. Ibid., IV, No. 24 (June 6-12, 1964), p. 1788.

23. There were even reports in June 1965 (which Tshombe promptly denied) that he had secretly met President Salazar in Lisbon. Ibid., V, No. 28 (July 3-9, 1965), p. 2399.

24. Ibid., CII, No. 3 (January 12-19, 1967), p. 3213, and $A R B$, IV, No. 2 (February, 1967), pp. $725 \mathrm{C}-726 \mathrm{~A}$.

25. $A R B$, IV, No. 6 (June, 1967 ), p. $800 A$.

26. $A D$, VII, No. 52 (December 24-31, 1967), pp. 3717-19. See also The Times (London), March 12, 1968, p. 6.

27. The data that follow were culled from the following materials: $A D, A R B$, East African Standard and The Nationalist. For the background of the struggle, see Douglas L. Wheeler, "The Portuguese and Mozambique: The Past Against the Future", in Davis \& Baker (eds.), op. cit., pp. 180-96; and in the same volume, Eduardo C. Mondlane, "The Struggle for Independence in Mozambique", pp. 197-213. See also James M. Dodson, "Dynamics of Insurgency in Mozambique", and Helen Kitchen, "Conversation with Eduardo Mondlane", both in Africa Report, XII, No. 8 (November, 
1967), pp. $5^{2-55} \& 3^{1-32} \& 49-51$, as well as several of the works mentioned in Footnote 17.

28. Legum, Africa Today, p. 7.

29. $A D$, VII, No. 5 (January 28 to February 3, 1967), p. 3238 .

3o. Tanganyika Standard, October 13, 1964.

31. These are UNHCR figures reported in Sven Hamrell (ed.), Refugee Problems in Africa (Uppsala: Scandinavian Institute of African Studies, 1967), pp. 14-15.

92. The chief concession Tanzania has made to Portugal's international sensitivities has been to request of FRELIMO that it stop bringing Portuguese prisoners over the border for detention in Tanzania. During 1966 there were fewer than 20 of these prisoners. East African Standard, December 30, 1966. See also Africa Report, XII, No. 2 (February, 1967), p. 23.

33. $A R B$, I. No. 10 (October, 1964), p. $173^{B}-\mathrm{C}$. See also the speeches by the Portuguese Foreign Minister in the East African Standard, October 23, 1964 \& May 11, 1965, and by the Tanzanian Vice-President Kawawa in the same paper, October 26, 1964.

34. $A D$, VII, No. 5 (January 28 to February 3, 1967), p. $3^{238}$. 35. The Nationalist, May 11, 1965 .

36. See East African Standard, December $1 \&$ 2, 1966, and April 15 \& 19, 1967. The Zambians have also accused the Portuguese troops of violating the border around Feira: see The Times (London), March 12, 1968, p. 6.

37. East African Standard, December 2, 1966, April 15, 1967 and September 21, 1967 .

38. The latest reports that surface-to-air missiles of Chinese manufacture and Russian "Sam" design are being installed in Tanzania are evidently not for use against Portuguese planes, which generally fly low. These missiles, which are thought to be capable of hitting aircraft at up to $5^{0,000}$ feet, are presumbly rather for use against high-altitude Rhodesian and South-African reconnaissance flights being made over Tanzania by adapted Canberra bombers. East African Standard, February 12, 1968.

39. Differing estimates appear in Colin Legum, The Observer (London), January 29, 1967; Anonymous, The New African, p. 13; and Newsweek, February 19, 1968, p. 29. This is particularly the case with over 50,000 additional Portuguese troops tied down in Portuguese Guinea.

40. For information, see Legum, Africa Today; Legum in The Observer, August 27, 1967; The Times (London), March 11, 1968.

41. Legum, Africa Today, p. 6.

42. David Devine, Sunday Times (London), October 10, 1965. 
43. The Guardian, September 6, 1967 and also The Times (London), March 11, 1968.

44. As quoted in Legum, Africa Today, p. 6.

45. A broader treatment of this subject is to be found in Hamrell (ed.), op. cit.

46. The data that follow are from Vernon McKay, "Southern Africa and Its Implications for American Foreign Policy", (processed paper, n.p., n.d.), p. 14. One rand equals ten shillings or \$ 1.40 .

47. From 368,000 rand in $1960-61$ to $51,102,000$ rand in $19^{6} 5^{-66}$; ibid., p. 17 .

48. See Legassick, op. cit., p. 6; and Colin and Margaret Legum, South Africa: Crisis for the West (London: Pall Mall, 1964), pp. 208-209.

49. $A D$, VIII, No. 1 (January 1-7, 1968), p. 3736. This book was published in 1967 in Cape Town by Nasionale Boekhandel Bpk. 5o. Ibid., VIII, No. 3 (January 14-20, 1968), p. 3753 .

51. New York Times, October 5,1967 .

52. See, for example, $A D$, II, No. 21 (May 19-25, 1962), p. 557; The Star (Johannesburg), September 29, 1962 and March 16, 1963; and Rosalynde Ainslie, The Unholy Alliance (London: The AntiApartheid Movement, 1963). The most recent discussion appeared in "The Council of Three", The Times (London, March 12, 1968.

53. See Marcum and Lowenstein, op. cit., pp. 272-73.

54. The Observer, August $27,1967$.

55. Ibid., and Kaunda's accusation that South-African police and army personnel had several times landed a helicopter at Katimo Mulilo on Zambia's southwestern boundary, close to the Caprivi Strip. $A R B$, IV, No. 10 (October, 1967), p. 891 A-C.

56. See Legassick, op, cit., pp. 3 \& 11 .

57. The shortest estimate was made by Chief Leabua Jonathan, who said that South Africa would take no more than six hours to overwhelm Africa, if they were attacked, $A D$, VIII, No. 1 (January $1-7,1968)$, p. $373^{6}$.

$5^{8}$. The growing relationships between South Africa and Malawi are discussed in a supplement to the Financial Mail (Johannesburg), January 12, 1968.

59. This point is admirably documented in Larry W. Bowman, "The Subordinate State System of Southern Africa", a paper given at the Tenth Annual African Studies Association meeting, Novem. ber 3,1967 , New York Gity (mimeo.).

6o. See, among others, Jack Halpern, South Africa's Hostages (Baltimore: Penguin, 1963); Leonard M. Thompson, "South Africa's 
Relations with Lesotho, Botswana and Swaziland", African Forum, II, No. 2 (Fall, 1966), pp. 65-77; and in the same issue, Leslie Rubin, "South Africa and her Immediate Neighbors: A Bibliographic Essay", pp. 78-84.

61. Bowman, op. cit., p. 6.

62. For Portuguese documentation on the detrimental effects sanctions against Rhodesia had on the Mozambique economy, see Some Portuguese Documents on the Question of Rhodesia (Lisbon: Ministry of Foreign Affairs, 1966) and The News (Lisbon), February 25, 1967. The Portuguese have gone so far as to claim $\$ 28,000,000$ in damages under Chapter $5^{\circ}$ of the UN Charter. I am indebted to Mr. Bowman's paper for many of the points and much of the data presented in the above paragraphs.

63. For an account of Malawi's role in sanctions evasion, see “The Sanctions Busters", Sunday Times (London), August 27, 1967, p. 9 . 64. See "Angola's Copper Railway", The Economist, CCXIX, No. 6402 (May 7, 1966), p. 619. Reliable sources indicate that for the first three-quarters of 1967 , only $4 \%$ of Zambia's imports and $11.8 \%$ of its exports (in weight) travelled along the Benguela route. In value, however, the figures are 17.2 of imports and $20.3 \%$ of exports,

65. See I. L. Griffiths, "Zambian Links with East Africa", East African Geographical Review (April, 1968).

66. See "The Tanganyika-Zambia Railway Project", Africa Report IX, No. 9 (November, 1964), p. 9; The Economist, CCXXIV, Nos. 2468 \& 2472 (August 12 and September 9, 1967), pp. 565-66 \& 872 .

67. $A D$, VII, No. 20 (May 14-20, 1967), p. 3395.

68. Uganda Argus, January 10, 1968.

69. For a discussion of Zambia's import substitutions and new trading partners, see R. B. Sutcliffe, "Zambia and the Strains of UDI", The World Today, XXIII, No. 12 (December, 1967), pp. 5o611; F. Taylor Ostrander, "Zambia and the Aftermath of Rhodesian UDI", African Forum, II, No. 3 (Winter, 1967), pp. 50-65; and John de St. Jorre, "Zambia's Economy: Progress and Perils", Africa Report, XII, No. 9 (December, 1967), pp. 36-39.

70. It is even argued by Bowman (op. cit.) that Rhodesia has become so economically dependent on South Africa that it would make little difference whether the government in Salisbury were black or white. He even suggests that a black Rhodesia might offer political advantages to the South Africans. For these provocative speculations, see pp. 14-15.

71. The Rhodesian economic picture since UDI is discussed in 
Larry W. Bowman, "Rhodesia since UDI', Africa Report, XII, No. 2 (February, 1967); and R. B. Sutcliffe, "Rhodesian Trade Since UDI", The World Today, XXIII, No. 10 (October, 1967), pp. 41822. Efforts to evade the sanctions are documented in Sunday Times (London), August 27 \& September 3, 1967. A first-rate theoretical and analytical discussion of sanctions appears in Johan Galtung, "On the Effects of International Economic Sanctions with Examples from the Case of Rhodesia", World Politics, XIX, No. 3 (April, 1967), pp. $37^{8-416 .}$

72. See the Sunday Times, August, 27, 1967 .

73. Data on South Africa are from Bowman, "State System", op. cit., p. 8. Data on Rhodesia are from George Kay, "The Distribution of African Population in Southern Rhodesia: Some Preliminary Notes" (Lusaka, The Rhodes-Livingstone Institute, 1964), pp. 9-10.

74. Ibid., and I. William Zartman, "Africa as a Subordinate State System in International Relations", International Organization, XXI, No. 3 (Summer, 1967 ), pp. $545^{-64}$.

75. Those who tend to emphasize the importance of neo-colonialism in Africa would take issue on this point.

76. Bowman ("The State System", op. cit., pp. 4-5) used the criteria and terminology proposed by Michael Brecher to define a subordinate state system. See Brecher, "International Relations and Asian Studies: The Subordinate State System of Southern Asia", World Politics, XV, No. 2 (January, 1963), pp. 213-35.

77. Zartman, op. cit., p. 549 .

78. The final communiqué released after President Nyerere's visit to Mali in April 1965 said that the two countries wanted to alert the world to the fact that South Africa, Portugal and Rhodesia had undertaken a war, in collusion with the Government of the Congo, to exterminate the black man in Africa. The Congo had fallen victim to "imperialist-inspired machinations". See East African Standard, April 19, 1965 \&c the Daily Nation (Nairobi), April 8, 1965. 79. See, for example, the speech of Nyerere on April 10, 1965, in his Freedom and Unity: Uhuru na Umoja (Dar es Salaam: Oxford University Press, 1966), p. 327; and the map in Waldemar A. Nielsen, African Battleline: American Policy Choices in Southern Africa (New York \& Evanston: Harper \& Row, 1965), opp. p. 1. A more recent statement by a Conservative M.P. put it this way: "Africa is divided by the Zambezi River. South of the Zambezi there is trade; north of it there is charity." Walter Paget, House of Commons, Parliamentary Debates, Hansard, v. 756, No. 34 (December 19, 1967), col. 1118 . 
8o. Bowman, "State System", op. cit., p. 5; and President Nyerere's statement at the OAU Heads of State Meeting in Accra, as reported in The Nationalist, October 27,1965 , and quoted on page 128 supra. At a conference in Kinshasa in February 1967 Heads of State and delegates from ten countries passed a resolution noting the danger represented by the presence of hostile forces in those countries under the control of racist minorities which have a common border with the Congo (Kinshasa), the Congo Republic, Zambia, and Tanzania. Significantly, there was no mention here of the OAU member states Malawi, Lesotho, and Botswana. So, by default or by implication, these states must either be under the control of racist minorities or else be neutral in this moral struggle.

81. See, for instance, Ravi L. Kapil, "On the Conflict Potential of Inherited Boundaries in Africa", World Politics, XVIII, No. 4 (July, 1966), pp. 656-73; and I. William Zartman, International Relations in the New Africa (Englewood Cliffs N. J.: Prentice-Hall, 1966), pp. 105-19.

82. For a discussion of the range of foreign-policy alternatives open to states, particularly with reference to intra-African relations in West and North Africa, see Zartman, International Relations, op. cit., pp. 87-105. 
